\title{
UNIVERSIDADE DE SÃO PAULO ESCOLA DE ENFERMAGEM DE RIBEIRÃO PRETO
}

MARCIANA GONÇALVES FARINHA

Acompanhamento Terapêutico como estratégia de inserção da pessoa em sofrimento psíquico na comunidade: estudo em um Programa de Saúde da Família 


\title{
MARCIANA GONÇALVES FARINHA
}

\author{
Acompanhamento Terapêutico como estratégia de \\ inserção da pessoa em sofrimento psíquico na comunidade: \\ estudo em um Programa de Saúde da Família
}

Tese apresentada ao Programa de Pós-Graduação de Enfermagem Psiquiátrica da Escola de Enfermagem de Ribeirão Preto da Universidade de São Paulo para obtenção do título de Doutor em Enfermagem Psiquiátrica, vinculada à linha de pesquisa "Enfermagem Psiquiátrica: o doente, a doença e as práticas terapêuticas".

Orientadora: Profa. Dra. Maria Cecília Morais

Ribeirão Preto 2006 
AUTORIZO A REPRODUÇÃO E DIVULGAÇÃO TOTAL OU PARCIAL DESTE TRABALHO, POR QUALQUER MEIO CONVENCIONAL OU ELETRÔNICO, PARA FINS DE ESTUDO E PESQUISA, DESDE QUE CITADA A FONTE.

\section{FICHA CATALOGRÁFICA}

Farinha, Marciana Gonçalves.
Acompanhamento Terapêutico como estratégia de inserção da pessoa em sofrimento
psíquico na comunidade: estudo em um Programa de Saúde da Família. / Marciana
Gonçalves Farinha; orientador Maria Cecília Morais. - Ribeirão Preto, SP, 2006. 186 f.
Tese (Doutorado - Programa de Pós-Graduação em Enfermagem. Área de Concentração:
Enfermagem Psiquiátrica) - Escola de Enfermagem de Ribeirão Preto da Universidade de
São Paulo.
1. Acompanhamento terapêutico. 2. Sofrimento mental. 3. Programa de Saúde da Família.
4. Fenomenologia. I. Título.




\section{Folha de Aprovação}

Marciana Gonçalves Farinha

Acompanhamento Terapêutico como estratégia de inserção da pessoa em sofrimento psíquico na comunidade: estudo em um Programa de Saúde da Família.

Tese apresentada ao Programa de Pós-Graduação de Enfermagem Psiquiátrica da Escola de Enfermagem de Ribeirão Preto da Universidade de São Paulo para obtenção do título de Doutor em Enfermagem Psiquiátrica,

Aprovado em:

\section{Banca Examinadora}

Prof. Dra. Maria Cecília Morais

Instituição:

Assinatura:

Profa. Dra. Elizabeth Ranier Martins do Valle

Instituição:

Assinatura:

Profa. Maria Alice Ornellas Pereira

Instituição:

Assinatura:

Prof. Dr. Sérgio Kodato

Instituição:

Assinatura:

Profa. Dra. Rozemere Cardoso de Souza

Instituição:

Assinatura: 


\section{DEDICATÓRIA}

À minha mãe, Zenaide, pelos valiosos ensinamentos de amor, coragem e determinação.

Ao meu pai, Hélio, que além da vida deu exemplo, que além do amor foi paciente, perseverante e presente.

Aos meus irmãos Marcelo, Margarete e Mônica, cada um a seu modo me ensina e motiva a continuar trilhando o caminho escolhido.

Aos meus cunhados Ari, Ordália e Nilton por partilharem comigo os ricos momentos em família.

Aos meus sobrinhos Marcela, Natália, Guilherme $e$ João Vítor que mostram, a cada dia, que a vida continua e segue seu curso. 


\section{AGRADECIMENTOS}

A DEUS, que sempre mostra que vale a pena prosseguir.

A Dra. Maria Cecília Morais - Cila, que, com sabedoria, acolhimento e generosidade, orientou-me e mostrou que a seu tempo tudo acontece. Obrigada pela compreensão e paciência e, ainda por mostrar que, além do resultado final, existe a riqueza do processo. Mais do que pesquisar me levou a desvelar o ser humano.

A Dra. Elizabeth Ranier Martins do Valle, pelo exemplo de pesquisadora, pelas valiosas contribuições e pela disponibilidade em ensinar.

A Dra. Maria Alice, pelas elucidativas sugestões no exame de qualificação, pelo carinho e disponibilidade para realizar a leitura deste trabalho.

A Dra Rozemere Cardoso de Souza, pela alegria e disposição que contribuiu com esse trabalho.

A Catalina, propulsora deste trabalho com o convite para pensar o Acompanhamento Terapêutico no Programa de Saúde da Família.

Ao Centro de Saúde Escola Profa. Dra. Maria Herbenia Oliveira Duarte e todos que lá me acolheram, disponibilizando não só espaço para a pesquisa, mas também trocas e aprendizado.

A Inês, pelo apoio, incentivo e generosidade em todos os momentos deste trabalho.

Ao Marcelo pelo incentivo ao longo deste trabalho e generoso apoio com a tradução do resumo.

À minha família, em especial à "tia Inês", pelo incentivo, compreensão e apoio constantes. 
A Rosita e a Rosângela, pelo companheirismo, participação, motivação e possibilidade de troca.

A Joseane, por partilhar comigo os caminhos, os encantos e os desencantos deste percurso.

A Adriana, que me ajudou, com seu trabalho, a percorrer o caminho do encontro comigo mesma e com o outro.

À equipe do Centro de Saúde da Prefeitura Municipal de Orlândia, pelo acolhimento e apoio constante.

Ao Dr Waldir Fares, pela consideração e respeito ao meu trabalho.

A Simone e Davi que partilharam comigo a árdua tarefa de estudar Heidegger.

A Cristina, Simone, Flávia, Marina, Daniela, Paula, Carolina, Luciana, Elaine, Lucimara, Adriana que mostram que partilhar e trabalhar em equipe pode ser a solução para vencer as dificuldades.

A Lourdes e Bernadete, pelo carinho e apoio que sempre ofereceram.

A Maria do Socorro, que prontamente contribui com esse trabalho.

A todos os professores e funcionários da Escola de Enfermagem de Ribeirão Preto, que, com profissionalismo e dedicação, atenderam às minhas solicitações e partilharam conhecimentos e estórias.

A todos os amigos, que estiveram presentes ao longo deste percurso. Obrigada pelo incentivo, apoio, respeito e carinho.

Aos colaboradores que participaram desta pesquisa. 
A certeza

de que estamos

sempre começando, de é preciso continuar, e a certeza de que podemos ser interrompidos antes de continuarmos

Fazer da interrupção

um caminho novo

Da queda um passo de dança, Do medo uma escada, Do sonho uma ponte, Da procura um encontro

Fernando Sabino 


\section{RESUMO}

\section{FARINHA, M. G. Acompanhamento Terapêutico como estratégia de inserção da pessoa} em sofrimento psíquico na comunidade: estudo em um Programa de Saúde da Família. 2006. 186 f. Tese (Doutorado) - Escola de Enfermagem de Ribeirão Preto, Universidade de São Paulo, Ribeirão Preto, 2006.

Este trabalho tem como objetivo compreender a percepção e os sentidos que portadores de sofrimento psíquico, familiares deles e agentes comunitários, que os atendem, têm do Acompanhamento Terapêutico para tratamento da pessoa em sofrimento mental. Colaboraram nesta pesquisa seis indivíduos que foram atendidos por um acompanhante terapêutico, um familiar de cada um desses indivíduos e cinco agentes comunitárias que visitaram as casas dos colaboradores. Foi realizado por meio de entrevista com uma questão norteadora. Os relatos foram gravados e transcritos na íntegra e analisados sob a perspectiva da metodologia qualitativa fenomenológica, fundada na Fenomenologia de Martin Heidegger, por autores que se aprofundaram nesse enfoque filosófico e estudiosos da Psicologia Fenomenológico-Existencial. Como resultados, os colaboradores mostraram um aumento qualitativo nas interações dos pacientes com os familiares, com a equipe de saúde e com a comunidade e, também, menor isolamento e maior independência em comportamentos de autocuidado, cuidado com seu espaço doméstico, maior adequação à sua proteção e desenvolvimento de habilidades. Com este estudo é possível reafirmar a importância do Acompanhamento Terapêutico para o tratamento de pessoas em sofrimento psíquico, bem como da equipe, no Programa de Saúde da Família.

Palavras-chave: Acompanhamento Terapêutico, Sofrimento mental, Programa de Saúde da Família, Fenomenologia 


\begin{abstract}
FARINHA, M. G. Therapeutic Accompaniment as insertion strategy of persons enduring psychic suffering in the community: A study of a Family Health Program. 2006. $186 \mathrm{f}$.

Doctoral Thesis - Escola de Enfermagem de Ribeirão Preto - Universidade de São Paulo, Ribeirão Preto, 2006.

This study's objective is to understand the perception and the feeling of persons enduring psychic suffering, their family, and community carer agents about Therapeutic Accompaniment it stops treatment of a person in mental distress. Six individuals that were seen to by therapeutic carers, one family member of each of these individuals and five community agents that visited the collaborator's houses collaborated in this research. It was carried out through an interview guided by a guiding question. The answers were recorded and fully transcribed and analyzed under the perspective of the phenomenological qualitative methodology, based on the Martin Heidegger's Methodology, by authors that specialized in this philosophical focus and followers of the Phenomenological-Existencial Psychology. As results, the collaborators showed that there was a qualitative raise in patients interactions with family members, with health team and with the community and, as well as a less isolation and more independence in self-care behaviors, care with their domestic space, more adequate behaviors regarding their protection, and development of abilities. Through this study, it is possible to reaffirm the importance of Therapeutic Accompaniment for the treatment of people in psychic distress, as well as the team, in the Family Health Program.
\end{abstract}

Key words: Therapeutic Accompaniment, mental disease, family health program, phenomenology. 


\section{RESUMEN}

\section{FARINHA, M. G. Acompañamiento terapéutico: una Estrategia de introducir el} portador de enfermedad psíquica en la comunidad - un trabajo en un Programa de la Salud da Familia. 2006. 186 p. Tesis (Doctorado) - Escola de Enfermagem de Ribeirão Preto, Universidade de São Paulo, Ribeirão Preto, 2006.

Este trabajo tiene como objetivo comprender la percepción y los sentidos que portadores del sufrimiento psíquico, sus familiares y agentes comunicarías que los atienden tienen del Acompañamiento Terapéutico para tratamiento del persona con enfermedad mental. Ayudaran en este trabajo seis individuos que fueran atendidos por un acompañante terapéutico, un familiar de cada un desees individuos e cinco agentes comunicarías que visitan las casas de los colaboradores. Fue realizado per medio de entrevista con una pregunta norteadota. Los relatos fueran grabados y transcritos en la íntegra y analizados bajo la perspectiva de la metodología cualitativa fenomenológica, de acuerdo en la Fenomenóloga de Martin Heidegger, autores que se aprofundaran en este enfoque filosófico y estudiosos de la Psicología Fenomenológico-Existencial. Cómo resultado, fue posible prenda un aumento cualitativo en las interacciones de los clientes con familiares, equipo de la salude y la comunidad, y, menor izó lamento y mayor independencia en comportamientos de autocuidado, cuidado con su espacio doméstico, comportamientos más adecuados con su protección, desarrollo de habilidades. Con este trabajo es posible confirmar de nuevo a importancia del acompañamiento terapéutico para el tratamiento de personas con enfermedad mental, bien como del equipe, en el Programa de Salud de la Familia.

Palabras-llave: Acompañamiento terapéutico, enfermedad psíquica, Programa de Salud de la Familia, Fenomenologia. 


\title{
SUMÁRIO
}

\begin{abstract}
APRESENTAÇÃOO 14
1 - INTRODUÇÃO 18

1.1 - Reforma Psiquiátrica: caminhos para a mudança 21

1.2 - A Reforma Psiquiátrica no Brasil: caminhos em construção 29

1.3 - Famílias: grupo primário do indivíduo 36

1.4 - Reabilitação psicossocial: a busca por um caminho 39

2 - PROGRAMA DE SAÚDE A FAMíLIA: estratégia de atendimento 44 ao usuário de saúde
\end{abstract}

2.1 - A Saúde Mental no Programa de Saúde da Família: compassos e 51 descompassos

3 - ACOMPANHAMENTO TERAPÊUTICO: a busca por novas 54 terapêuticas para o tratamento em saúde mental

3.1 - Objetivos $\quad 62$

4 - METODOLOGIA: compreendendo o processo da pesquisa 63

4.1 - Heidegger: em busca de sentido para a existência humana 69

4.2 - O encontro com os colaboradores 76

4.2.1 - Aspectos Éticos

4.2.2 - Instrumento 77

4.2.3 - Apresentando o espaço onde o Acompanhamento Terapêutico se 78 inseriu

5 - CONHECENDO OS COLABORADORES 81

5.1 - A pessoa em sofrimento psíquico $\quad 80$

5.1.1. - A título de uma apresentação $\quad 80$

5.1.1.1 - Apresentando Ari 81

5.1.1.1.1 - Síntese do Acompanhamento Terapêutico de Ari 83

5.1.1.2 - Apresentando Vânia 84

5.1.1.2.1 - Síntese do Acompanhamento Terapêutico de Vânia 85

5.1.1.3 - Apresentando Elaine $\quad 87$

5.1.1.3.1 - Síntese do Acompanhamento Terapêutico de Elaine 88

$\begin{array}{ll}\text { 5.1.1.4 - Apresentando Edivânia } & 90\end{array}$ 
5.1.1.4.1 - Síntese do Acompanhamento Terapêutico de Edivânia 92

5.1.1.5 - Apresentando Sandra 93

5.1.1.5.1 - Síntese do Acompanhamento Terapêutico de Sandra 94

5.1.1.6 - Apresentando Daniela 97

5.1.1.6.1 - Síntese do Acompanhamento Terapêutico de Daniela 99

$\begin{array}{ll}5.1 .2 \text { - Categorias temáticas } & 100\end{array}$

5.2 - O familiar da pessoa em sofrimento psíquico 103

$\begin{array}{ll}5.2 .1 \text { - Apresentando o familiar } & 103\end{array}$

$\begin{array}{ll}5.2 .2 \text { - Categorias temáticas } & 105\end{array}$

$\begin{array}{ll}5.3 \text { - As agentes comunitárias } & 107\end{array}$

$\begin{array}{ll}\text { 5.3.1 - Apresentando a agente comunitária } & 107\end{array}$

$\begin{array}{ll}5.3 \text { - Categorias temáticas } & 108\end{array}$

6 - DESVELANDO OS SENTIDOS DO ACOMPANHAMENTO 112 TERAPÊUTICO

6.1 - A compreensão se desvela nos discursos 113

6.1.1 - A pessoa em sofrimento psíquico 113

6.1 .2 - - Os familiares da pessoa em sofrimento psíquico 127

$\begin{array}{ll}\text { 6.1.3 - As agentes comunitárias } & 138\end{array}$

6.2 - A vivência da enfermidade mental: percepções e sentidos se 153 desvelam à luz do pensamento de Heidegger

7 - HORIZONTES DE COMPREENSÃO 168

$\begin{array}{ll}\text { REFERÊNCIAS BIBLIOGRÁFICAS } & 174\end{array}$

ANEXOS 


\section{APRESENTAÇÃO}

Percorrendo uma trajetória de pesquisa iniciada na graduação em Psicologia, na Faculdade Federal de Uberlândia, realizei dois anos de iniciação científica. Instigava-me pesquisar e saber mais como tratar temas importantes e de interesse para o ser humano. Comecei investigando sobre a formação de professores; posteriormente, ainda na graduação, realizei estudos sobre o ensino da psicanálise.

Buscando cursos, palestras e textos a respeito da sexualidade, fiz o curso “Capacitação Profissional em Educação Afetivo-Sexual”, na Escola Básica da Universidade Federal de Uberlândia, no período de 1995/96, em que li, discuti e aprofundei-me nos temas ligados à sexualidade humana. Apliquei esses conhecimentos em grupos com préadolescentes e adolescentes, ainda quando cursava Psicologia. A partir dessa experiência, voltei-me ao interesse da gravidez na adolescência. Por que as jovens engravidavam e continuam a engravidar até hoje, apesar de todas as informações vinculadas na mídia escrita e falada? Começava a se desvelar um universo novo e instigante para mim, o qual merecia atenção.

Ainda durante a graduação, fiz o estágio de atendimento clínico e de acompanhamento terapêutico. Neste último além dos atendimentos e supervisões, participei de grupo de estudo, espaço muito importante para a minha formação profissional.

Durante o ano de 1998, já formada, continuei na cidade de Uberlândia, trabalhando, voluntariamente, como acompanhante terapêutica em um Serviço de Saúde Mental Público. Nesse mesmo ano, iniciei atividade clínica em consultório e em 
acompanhamento terapêutico na cidade de Ribeirão Preto, trabalhando por dois anos nas duas cidades.

Ainda em 1998, fui convidada pela Profa. Dra. Maria Lúcia Castilho Romera, da Universidade Federal de Uberlândia, a participar de uma pesquisa sobre a paternidade na adolescência, tema que se desvelou muito pertinente, pela minha área de interesse e também pelo aumento do número de jovens que estão se tornando pais ainda adolescentes.

Buscando conhecer mais sobre o universo da sexualidade, em 1999 fiz uma disciplina, como aluna especial, na Faculdade de Filosofia, Ciências e Letras de Ribeirão Preto - USP, ministrada pela professora Dra. Maria Alves de Toledo Bruns intitulada “Sexualidade e História da Repressão Humana”. A partir de atividades realizadas nessa disciplina, iniciei um trabalho-piloto para compreender o universo da sexualidade das profissionais do sexo.

Em 1999, iniciei o mestrado trabalhando com a temática "A Maternidade da Adolescente Profissional do Sexo" e objetivei conhecer como adolescentes-mães e profissionais do sexo se relacionavam com seus filhos, sendo profissionais do sexo.

Em maio de 2000, assumi o cargo de Psicóloga do Serviço de Saúde Mental da Prefeitura Municipal de Orlândia - SP, cidade distante $60 \mathrm{~km}$ de Ribeirão Preto, sendo responsável pelo atendimento a pessoas com necessidades especiais, como psicóticos, alcoolistas, drogadictos e deficientes físicos e, ainda, atendimento clínico a crianças, adolescentes e adultos.

Esses atendimentos, aliados à prática do acompanhamento terapêutico, às supervisões, participação em simpósios, congressos e conferências, possibilitaram-me a reflexão sobre a importância de um trabalho de apoio, continência e reinserção desses pacientes na comunidade da qual eles fazem parte. 
Em 2002, dei início à prática docente atuando em três universidades: Faculdade de Filosofia, Ciências e Letras de Catanduva - FAFICA (ministrando a disciplina Psicologia aplicada à Odontologia); Centro Universitário Moura Lacerda (ministrando as disciplinas Psicologia aplicada a administradores, Psicologia Organizacional II e Comportamento Organizacional); Faculdade de Filosofia, Ciências e Letras de Ituverava (ministrando as disciplinas Metodologia Científica e Psicologia Educacional).

Ainda em 2002, fui convidada pela Dra. Catalina Camas Cabrera a participar das reuniões do GEAVIDAS (Grupo de Estudo e Atenção a Vítimas de Violência Doméstica e Abuso Sexual), ancorado ao Hospital das Clínicas de Ribeirão Preto que se reúne no Centro de Saúde Escola Profa. Dra. Maria Herbenia Oliveira Duarte e tem como objetivo capacitar novos profissionais para atender a famílias de risco e criar recursos de atendimento e reabilitação para estas famílias, além de contribuir nas supervisões dos agentes comunitários e estagiários de Psicologia.

Pensar a reabilitação, hoje, com as inúmeras dificuldades e problemas enfrentados pelos indivíduos com sofrimento psíquico é o desafio que me inquietou e instigou a elaborar o projeto “O Atendimento ao Indivíduo com Sofrimento Psíquico na Perspectiva de um Programa de Saúde da Família" que foi aprovado na seleção do Programa de Pósgraduação de Enfermagem Psiquiátrica da Escola de Enfermagem de Ribeirão Preto - USP, em 2002, dando início ao presente trabalho.

Este projeto foi desenvolvido no período de 2003 a 2006 e teve como objetivo conhecer a percepção e os sentidos que portadores de sofrimento psíquico, seus familiares e agentes comunitários que os atendem têm do acompanhamento terapêutico com intuito de ampliar as opções de tratamentos para esses indivíduos.

Deste momento em diante, passo a discorrer no plural, porque faz parte deste trabalho minha orientadora Profa. Dra. Maria Cecília Moraes. 
Convidamos o leitor a seguir conosco e conhecer nosso percurso realizado nesta pesquisa.

Capítulo 1 - serão discutidas a reforma psiquiátrica e a reabilitação psiquiátrica à luz de vários autores que contribuem com reflexões para nossa compreensão.

Capítulo 2 - mostrar-se-á, por meio da história, o início do Programa de Saúde da Família e como ele se desenvolveu no Brasil, subsidiando assim esta pesquisa.

Capítulo 3 - será mostrado o acompanhamento terapêutico com a caracterização histórica e seus principais pressupostos.

Capítulo 4 - a partir dos pressupostos básicos da metodologia fenomenológica, será apresentada a trajetória de acesso e de atendimento aos portadores de sofrimento psíquico.

Capítulo 5 - conheceremos, neste capítulo, os colaboradores deste estudo e as categorias que emergiram de seus discursos.

Capítulo 6 - serão discutidas a análise e a compreensão dos discursos dos portadores de sofrimento psíquico, do seu familiar e do agente comunitário que o atende à luz do referencial teórico deste trabalho, os autores da Psicologia Fenomenológico-Existencial e as idéias de Martin Heidegger.

Capítulo 7 - serão apresentadas as conclusões, contribuições e perspectivas deste estudo para os profissionais de saúde que trabalham com essas pessoas e para todos os interessados. 
1 - INTRODUÇÃO 
No momento sócio-histórico-cultural em que vivemos, nos deparamos com um processo acelerado de mudanças em vários âmbitos que repercutem no nosso cotidiano, demarcando novas maneiras de estar no mundo, estimulando a individualidade em detrimento do coletivo e agravando o sentimento de solidão e insegurança.

Se por um lado, os avanços tecnológicos trazem contribuições invejáveis para o desenvolvimento global, por outro, este intensifica o consumismo da sociedade, em que tudo é efêmero e substituível, propiciando um esvaziamento de relações mais significativas na existência cotidiana.

Uma sociedade que a cada dia se torna mais especializada, exigindo das pessoas constante busca pelo novo, como cursos e especializações, diminuindo, para isso, o tempo de convivência com os familiares e amigos.

O homem moderno vive uma crise de identidade que faz parte desse processo de constante mudança que estaria deslocando as estruturas socioeconômicas e culturais da sociedade atual, de maneira que os cenários culturais de classe, gênero, sexualidade, etnia, raça e nacionalidade estão sendo abalados e, com eles, as referências que ancoram e dão sustentação ao indivíduo, portanto, mais segurança no mundo social (HALL, 2002).

(...) o sujeito assume identidades diferentes em diferentes momentos, identidades que não são unificadas ao redor de um "eu" coerente. Dentro de nós há identidades contraditórias, empurrando em diferentes direções, de tal modo que nossas identificações estão sendo continuamente deslocadas (...) à medida em que os sistemas de significação e representação cultural se multiplicam, somos confrontados por uma multiplicidade desconcertante e cambiante de identidades possíveis, com cada uma das quais poderíamos nos identificar - ao menos temporariamente (HALL, 2005, p. 13).

Scabello (2006) enfatiza que essa mudança estrutural da sociedade a que estamos assistindo estaria produzindo um sujeito com uma identidade móvel, em contínua e constante formação e transformação, de acordo com os sistemas sociais dominantes. 
Percebemos que no momento atual há uma pressa, uma necessidade de correr em

que:

(...) o vínculo humano é substituído pela rapidez; a qualidade de vida, pela eficiência; a fruição livre de normas e de cobranças, pelo frenesi. Foram-se a ociosidade, a contemplação, o relaxamento voluptuoso; o que importa é a auto-superação, a vida em fluxo nervoso, os prazeres abstratos da onipotência proporcionados pelas intensidades aceleradas. Enquanto as relações reais de proximidade cedem lugar aos intercâmbios virtuais, organiza-se uma cultura de hiperatividade caracteriza pela busca de mais desempenho, sem concretude e sem sensorialidade, pouco a pouco dando cabo dos fins hedonistas (LIPOVETSKY, 2004, p. 80-1).

Ressaltamos que, na liberação dos costumes e dos valores presentes em nossa sociedade, as relações sofreram e ainda sofrem transformações percebidas nos modelos atuais de relacionamento amoroso, família, trabalho e entre os gêneros, tornando a vinculação entre as pessoas mais complexa do que outrora, quando a norma tradicional, de um lado, impunha a cada um o seu lugar na ordem social e, por outro, lado acolhia a todos, favorecendo maior participação no ambiente em que viviam.

Todas essas transformações que a sociedade vem sofrendo têm acarretado dificuldade de vinculação entre as pessoas, de adaptação e fluidez nas relações e maior quantidade de estressores, levando mais pessoas a sentirem-se sozinhas, tristes, desamparadas sendo umas das causas de adoecimento emocional e mental na atualidade.

Nessa perspectiva de modernidade pensar o enfermo mental que, em sua condição humana de existir, se encontra doente ou incapacitado para exercer suas habilidades, exige do profissional que o atende a capacidade de estar junto dele, estando esse outro doente ou potencialmente doente, porque se apresenta com dificuldades emocionais podendo ser constantes e recorrentes, configurando-se como ser-enfermo-mental.

Com intuito de pensarmos o Acompanhamento Terapêutico como tratamento para pessoas em sofrimento psíquico discorrermos, nos próximos itens, sobre a Reforma 
Psiquiátrica ocorrida no mundo e no Brasil, família e a reabilitação psicossocial para cumprir esse propósito.

\section{1 - Reforma Psiquiátrica: caminhos para a mudança}

A assistência ao doente mental tem sido tema de muita discussão e profundas reformas na atualidade. Vale dizer que essa transformação, na maneira como vemos e tratamos o enfermo mental, é recente e marcada por muita luta. Para melhor compreendermos esse momento histórico, discorreremos sobre dados históricos que levaram à mudança.

Desde tempos remotos, a doença mental e, conseqüentemente, a forma de tratá-la, sofreram mudanças de acordo com a compreensão do homem de cada época. Para Hipócrates e Platão, a loucura era considerada como doença orgânica, devido ao desequilíbrio dos humores, déficits orgânicos que afetam o corpo e sobem ao cérebro, causando desorganização. O tratamento ideal consistia em expulsar do organismo as substâncias que faziam mal, combinando, para isso, terapêuticas catárticas, mudança da conduta que estava prejudicando o indivíduo, regime alimentar e alteração dos hábitos de vida, para equilibrar os humores (COSTA-ROSA, 2000).

Na Idade Média, a loucura ou qualquer comportamento que fugisse do modelo aceito socialmente eram classificados como possessão diabólica. O tratamento ficava a cargo da Igreja que indicava peregrinações a lugares santos, orações, rituais, exorcismo, uso de ervas e a fogueira, visando à adaptação do indivíduo ao meio em que vivia (COSTA-ROSA, 2000).

A Idade Moderna analisava a loucura pela ótica da moral, na figura da desrazão, compreendida pela perspectiva de um universo ético. Toda conduta escandalosa, impura ou maligna precisava ser corrigida; pessoas com comportamentos que divergissem das normas 
sociais da época eram tratadas como doentes e mantidas sob vigilância. A terapêutica preconizada era a internação, para purificação pelos banhos de imersão e transfusão de sangue. O cuidado era feito pela polícia, responsável pela internação, e as pessoas mais experientes, que cuidavam dos enfermos, ficavam com a incumbência dos cuidados médicos (AMARANTE, 2000).

Com esse histórico de opressão e visão reducionista da loucura no ser humano, no século XVIII surge uma nova denominação, o indivíduo alienado. Um dos nomes referenciais dessa época é Pinel. Defendeu o modelo asilar de tratamento para a loucura que passa a ser responsabilidade da medicina. A terapêutica prescrita consistia em medicamentos e internação. Enfatizava as determinações orgânicas dos problemas, preconizando, assim, o paradigma da doença-cura, em que o doente deve ser tratado e o saber está depositado na figura do médico e não mais na Igreja ou na polícia, como outrora (COSTA-ROSA, 2000). Vale ressaltar que os manicômios passam a ser os responsáveis pelo cuidado da loucura e o fazem com a segregação, exclusão e morte.

Pinel não liberta o enfermo mental promovendo cidadania, apenas muda a forma de aprisionamento, e a loucura passa a ser objeto de saberes e práticas da medicina com o campo de estudo da doença mental. No século XVIII, a tecnologia hospitalar imprime uma nova ordem social, a assistência e tutela, favorecendo a dependência e a cronicidade do enfermo mental (COSTA-ROSA, 2000; AMARANTE, 2000).

A partir do século XIX, a psiquiatria seguiu uma orientação positivista, com um modelo eminentemente centrado na medicina biológica. Nasce, assim, a psiquiatria, que foca seu interesse em descrever e quantificar os distúrbios nervosos. Busca-se a ordenação dos sujeitos visando ao conhecimento objetivo do homem. Surge, então, uma divisão objetiva da loucura, com a classificação dos transtornos em grupos de sintomas (COSTA-ROSA, 2000; 
AMARANTE, 2000). Pudemos perceber, nas internações, a exclusão do enfermo sem trabalhar sua singularidade.

A doença se desdobra por agrupamento - diversificação de seus sintomas, inscrevendo no espaço hospitalar tantas subdivisões quanto são as grandes síndromes comportamentais que ela apresenta - (...) funda-se uma ciência a partir do momento em que a população dos insanos é classificada: esses reclusos são efetivamente, doentes, pois desfilam sintomas que só resta observar (CASTEL, 1978, 83).

Até meados do século $\mathrm{XX}$, o hospital psiquiátrico era lugar de habitação não somente dos doentes mentais, mas de qualquer um que ameaçasse a lei e a ordem social vigente ou que tivesse dificuldade de reintegração no espaço social e, assim, o indivíduo era considerado inadaptado, improdutivo e marginalizado da sociedade como os andarilhos, prostitutas, ladrões, leprosos, vagabundos e, ainda, os deficientes físicos e mentais (AMARANTE, 2000). Nessa perspectiva, funcionavam como depósito de todas as pessoas consideradas indesejadas ou perturbadoras da ordem, assumindo para si a função de custódia com um grande número de pessoas internadas.

Antes de prosseguirmos nessa trajetória histórica, faz-se importante pararmos para refletir sobre essa realidade. Goffman (1974), em um estudo sociológico, faz uma reflexão sobre o indivíduo internado em asilos ou manicômios, locais esses denominados, por ele, de instituições totais, já que têm autonomia sobre a pessoa em sofrimento mental internada dentro de seus muros. Nessas instituições, as pessoas convivem por algum tempo compartilhando o mesmo espaço, as atividades cotidianas e as regras da instituição. Foucault (1984, 1979) faz uma crítica a esse modelo de tratamento que, para ele, objetiva dominar o indivíduo pelo controle e coerção, para impor as normas do proibido e do permitido que são ditadas pela sociedade capitalista.

Voltando à nossa contextualização histórica, percebemos, nessa conjuntura de internações infindáveis e longas, o surgimento de vários movimentos que visavam a 
humanizar o atendimento em saúde mental, preconizando práticas menos coercitivas e violentas. Esses movimentos ocorreram ao longo de vários anos e havia uma conjuntura política e social que deu as bases a essa reformulação, como passamos a discorrer.

a) Contexto histórico de guerra: ênfase na solidariedade nacional e investimento na reabilitação de soldados e/ou civis com problemas associados à guerra (VASCONCELOS, 2000). O fantasma dos campos de concentração da Segunda Guerra Mundial contribuiu para a condenação de qualquer tipo de microinstituição para desadaptados sociais (BOTEGA, 1995), como por exemplo: as comunidades terapêuticas nos Estados Unidos e Inglaterra, durante e após a Segunda Guerra.

b) Conjunturas históricas de escassez de força de trabalho e revalorização do trabalho humano: estímulo ao investimento e à reabilitação de grupos populacionais considerados improdutivos.

c) Processos de transição demográfica, com aumento da população idosa, desestruturação e transformação das estruturas familiares convencionais, aumento do número de arranjos domiciliares de famílias matrifocais a pessoas sozinhas, e de ocupação do mercado formal de trabalho pela mulher; ampliação de serviços sociais substitutivos ou, ainda, de suporte ao cuidado informal prestado pela família e pelas mulheres no âmbito doméstico do membro doente, e também, mudanças em direção a uma crescente individualização.

d) Conjunturas políticas de democratização, processos revolucionários ou de emergência de movimentos sociais populares em geral, processos políticos sociais de afirmação dos direitos civis e políticos (reconhecimento da existência e dos direitos dos doentes mentais, de trabalhadores, usuários e familiares, atuando diretamente no campo da saúde mental). 
e) Desenvolvimento de sistemas maciços de bem-estar social e/ou contextos de afirmação dos direitos sociais; ampliação de programas e seguros sociais para os grupos populacionais dependentes em geral, incluindo os doentes mentais, tanto de público estatal como do Terceiro Setor ${ }^{1}$.

f) Paradoxalmente, políticas neoliberais de desinvestimento em políticas sociais públicas, em geral, induzem a processos de desospitalização, já que a manutenção da psiquiatria convencional constitui item de custo elevado para o Estado. A tendência é gerar processos sem garantia de assistência na comunidade, provocando negligência social e aumento da população de rua, incluindo portadores de transtorno mental.

g) Mudanças nas formulações epistemológicas, filosóficas, teóricas e práticas em ciências humanas e, particularmente, no campo psicológico.

h) Desenvolvimento de terapêuticas psicofarmacológicas, a partir do final dos anos 50, com os neurolépticos, possibilitando maior controle dos sintomas mais disruptivos e o tratamento em ambientes menos coercitivos e menos isolados (VASCONCELOS, 2000). O uso de abordagens terapêuticas: da psicanálise em instituições, técnicas grupais, psicoterapia breve, etc., socioterapias, terapia ocupacional, laborterapia, comunidades terapêuticas, entre outras (BOTEGA,1995).

i) Estratégias de aggiornamento (modernização) e/ou humanização pela corporação médica, para responder às críticas à psiquiatria convencional. Surge a idéia de que a internação psiquiátrica não deveria ser vista como centro da assistência psiquiátrica; ela deveria ser integrada a estruturas extramurais - ambulatórios e centros de saúde regionalizados e não apenas a macro-hospitais psiquiátricos (BOTEGA,1995). As contribuições da psicanálise, das ciências sociais e das ciências do comportamento passaram a atuar de modo operativo em vasta gama de serviços em hospital geral. A instalação de

\footnotetext{
${ }^{1}$ Terceiro Setor são empresas de utilidade pública sem fins lucrativos.
} 
serviços de saúde mental no hospital geral também tem sido reconhecida como importante recurso de atendimento e de formação de profissionais da saúde, propiciando-lhes conhecimento interdisciplinar e capacitação para lidar com problemas psicossociais.

Vale ressaltar que, no período do pós-guerra, em que a concentração de pessoas "improdutivas" cresceu, os mutilados da guerra e todos os outros indivíduos que fogem do padrão de normalidade, imposto pela ordem social capitalista vigente, geram discussões, causando desencontros nessa prática asilar, promovendo o surgimento de um novo modelo assistencial para as pessoas em sofrimento mental.

As reformas no modelo assistencial em saúde mental ocorridas após a Segunda Guerra Mundial questionaram o papel e a natureza, tanto da instituição asilar quanto do saber psiquiátrico, propondo novas maneiras de reorganização (AMARANTE, 2000).

A reforma na Europa e nos EUA que envolveu e, por vezes, transformou em várias medidas os sistemas de saúde mental foi impulsionada pelo intento de renovar a capacidade terapêutica da Psiquiatria, liberando-a das funções arcaicas de controle social, coação social e segregação. Nesse contexto cultural e político, a desinstitucionalização era uma nova ordem central utilizada para muitos e diferentes objetivos: para os reformadores, ela simbolizava a possibilidade da abolição de todas as instituições de controle social e se emparelhava à perspectiva antipsiquiátrica; para os administradores, ela era, sobretudo, um programa de racionalização financeira e administrativa, sinônimo de redução de leitos hospitalares (ROTELLI et al. 2001).

Rotelli et al. (2001) e Costa-Rosa (2000) fazem uma crítica às mudanças ocorridas no modelo de tratamento em saúde mental. Para eles, nos EUA e na Europa, o que ocorreu foi um processo de desospitalização e diminuição dos leitos hospitalares, muitas vezes realizado de maneira brusca, sem a criação de serviços substitutivos na comunidade e sem nenhum trabalho de inserção dos indivíduos egressos da internação em seus lares e no ambiente social; 
portanto, apesar de fora dos muros hospitalares, eles continuaram excluídos do ambiente social e sem possibilidades de reabilitação de suas funções e habilidades para se integrar à sociedade.

Vale ressaltar que esse processo de desinstitucionalização trouxe uma diminuição do número de vagas para internação psiquiátrica, mas em contrapartida, um aumento de recidivas e reinternações. Foi um processo vindo de cima para baixo, em que não houve um preparo dos técnicos em saúde mental, dos familiares dos enfermos internados e também dos próprios enfermos, um planejamento para uma gradual alta hospitalar e também a criação de serviços na comunidade que visassem à prevenção de novas crises e à reabilitação dessas pessoas (ROTELLI et al. 2001).

O modelo italiano de desinstitucionalização promoveu uma mudança ampla que começou entre os técnicos de saúde mental, ou seja, as pessoas que cuidavam diretamente dos enfermos mentais. Eles realizaram a mudança de maneira gradativa e, concretamente, no interior da própria instituição psiquiátrica, promovendo a mudança com o envolvimento de todos os atores do processo de desinstitucionalização. Esses técnicos que trabalhavam no interior das instituições transformaram a organização, as relações e as regras do jogo, exercitando seu papel de psiquiatras, psicólogos, enfermeiros, etc. Sobre essa base também, os pacientes se tornaram sujeitos e a relação terapêutica foi utilizada para chamar à responsabilidade o poder que é inerente ao usuário e também aos administradores locais responsáveis pela saúde mental, aos técnicos pelas estruturas sanitárias, aos políticos, etc. (ROTELLI et al. 2001).

A crítica ao manicômio, desenvolvida na Itália, dele fez, de verdade, não tanto pela psiquiatria quanto de sua própria identidade, um ponto que ilumina também o presente. De fato, como se pode depreender do balanço crítico, o modelo manicomial esboçado 
anteriormente faliu, seja no objetivo de superar sua cronicidade, seja no objetivo de liberar-se da sua função de coação e internação.

Para Rotelli et al. (2001), a desinstitucionalização sobrevive à crise da saúde mental que dela fez bandeira e revela-se com as orientações neoliberais e conservadoras de redimensionamento do próprio welfare. O welfare state (estado de bem-estar) integra o projeto de reconstrução nacional e significa a aceitação da democracia liberal em oposição ao bolchevismo, na Itália.

Para melhor compreensão da enfermidade mental e seu tratamento faz-se importante refletirmos sobre a diferença entre desospitalização, transinstitucionalização e desinstitucionalização.

Desospitalização centra-se no fechamento de hospitais psiquiátricos como ocorreu nos EUA e em alguns países da Europa. Transinstitucionalização focaliza a diminuição dos leitos psiquiátricos, mas em contrapartida, aumento de asilos, casas de repouso ou qualquer instituição que tenha a finalidade de cuidar dos enfermos mentais, não tendo como princípio estimular a inserção do enfermo mental no convívio social e familiar e também propiciar que a comunidade participe desse processo de mudança. Desinstitucionalização, modelo fundamentalmente político, ao contrário, pauta-se no envolvimento de toda a sociedade local no processo de mudança das instituições públicas de saúde, buscando alternativas para uma reorganização da sociedade que olhe/trate o doente como ser humano e não o exclua, ao contrário, o integre ao contexto social, favorecendo, assim, a produção de vida, de sentido e de sociabilidade (BASAGLIA, 1985).

E no Brasil como isso aconteceu? 


\section{2 - A Reforma Psiquiátrica no Brasil: caminhos em construção}

No Brasil, a reforma psiquiátrica seguiu o modelo italiano de desinstitucionalização que, de acordo com Pitta (1984), iniciou-se, pelo menos, quarenta anos após os movimentos ocorridos na Europa e América do Norte. Com o intuito de compreendêlo, faremos uma retrospectiva do momento histórico, político, social e cultural do nosso país que coexistia nessa época, repercutindo nesse processo de mudança.

A sistematização dos serviços em saúde mental tem por base os principais Estados do Sudeste, como cenário da maior rede de serviços psiquiátricos no país. A periodização se inicia em 1978, com a abertura política à reemergência dos principais movimentos sociais no país, após a repressão pelo regime militar. O Movimento de Trabalhadores de Saúde Mental (MTSM) inicia um questionamento das políticas de assistência psiquiátrica vigentes na época. Em consonância com Vasconcelos (2000), verificamos a existência de cinco períodos no processo de reforma psiquiátrica no Brasil:

$1^{\circ}$ Período: Mobilização na Sociedade Civil contra o Asilamento Genocida e a Mercantilização da Loucura; Protoformas das “Ações Integradas de Saúde”: 1978-1982 (São Paulo e Minas Gerais) e 1978-1980 (Rio de Janeiro).

a) A emergência do Movimento de Trabalhadores de Saúde Mental (MTSM): juntamente com movimentos sociais populares que surgem no ano de 1978, o MTSM constitui o resultado de articulações prévias em congressos de psiquiatria e movimentos de renovação médica, ganha corpo com a visita de lideranças mundiais da psiquiatria crítica, principalmente de Franco Basaglia ${ }^{2}$. Uma característica marcante do MTSM nesse período é o fato de ele ser completamente externo ao aparelho do Estado. Os principais objetivos foram:

\footnotetext{
2 A experiência de Basaglia, no hospital psiquiátrico de Gorizzia, com a aprovação da Lei 180, em 1978 promove a ruptura com o paradigma clínico psiquiátrico ao desconstruir os aparatos científicos, legislativos, administrativos, culturais e políticos que lhe dão sustentação, ao entender o manicômio como uma das
} 
$\checkmark$ Denúncias e mobilização pela humanização dos hospitais psiquiátricos identificados com campos de concentração;

$\checkmark$ Denúncia da indústria da loucura nos hospitais privados;

Denúncia e reivindicações por melhores condições de trabalho nos hospitais psiquiátricos;

$\checkmark$ Primeiras reivindicações pela expansão de serviços ambulatoriais em saúde mental.

b) É feita a primeira tentativa de mudança do sistema global de saúde no país, o plano PREV -SAÚDE, que mais tarde foi chamado de reforma sanitária, numa iniciativa do movimento dos trabalhadores em geral.

$2^{\mathbf{0}}$ Período: Expansão e Formalização do Modelo Sanitarista (Ações Integradas de Saúde e de Sistema Único de Saúde); Montagem de Equipes Multiprofissionais Ambulatoriais de Saúde Mental; Controle e Humanização do Setor Hospitalar; Ação a partir do Estado; em 1980 no Rio de Janeiro e em 1982 em São Paulo e Minas Gerais.

No Rio de Janeiro, em 1980, o processo chamado de "Co-Gestão", entre o Ministério da Saúde e o Ministério da Previdência, e, em São Paulo e Minas Gerais, a vitória dos governos estaduais oposicionistas (Tancredo Neves e Franco Montoro), em 1982, permitiram a entrada de lideranças do MTSM nas secretarias estaduais de saúde, possibilitando, com isso, uma intervenção crescente nos hospitais psiquiátricos estatais e privados.

Os principais objetivos da plataforma política do MTSM naquela conjuntura foram:

instituições da violência, e implementa uma negação ativa dessa instituição, estimulando a criação de novos serviços de base comunitária, embora reforce o poder do psiquiatra, ativa o poder de outros profissionais da equipe (ROTELLI et al. 2001). 
a) Não-criação de novos leitos em hospitais psiquiátricos especializados, e redução onde é possível e/ou necessário;

b) Regionalização das ações em saúde mental, integrando os setores internos dos hospitais psiquiátricos, ou específicos, com serviços ambulatoriais em áreas geográficas de referência;

c) Controle de internações na rede conveniada de hospitais psiquiátricos privados com centralização das emissões de guias de Autorização de Internação Hospitalar (AIH) nos serviços de emergência do setor público;

$3^{\circ}$ Período: Fechamento Temporário do Espaço Político de Mudanças a partir do Estado; Emergência da Luta Antimanicomial e Transição da Estratégia Política em Direção ao Modelo da Desinstitucionalização Psiquiátrica: 1987-1992.

Nesse período, identificamos:

a) Fechamento Temporário do Espaço Político para os interesses democráticos populares e para as políticas de saúde mental identificadas com esses interesses. No Rio Grande do Sul, o governador estadual permitiu um avanço significativo nas políticas de saúde mental, a partir de 1986;

b) Testemunho da consolidação de algumas conquistas feitas no período anterior, como a Constituição de 1988, e aprovação, em 1990, da Lei Orgânica de Saúde que aponta para construção de um Sistema Único de Saúde;

c) Nesse processo, uma ala do MTSM desenvolve uma crítica à burocratização do conjunto do próprio movimento, no sentido de que o período anterior tendeu a se restringir às lutas a partir de dentro do aparelho de Estado. Salientou-se, também, a necessidade de realiança do Movimento de Saúde Mental com os movimentos populares e com a opinião pública em geral. 
$4^{\circ}$ Período: Avanço e Consolidação da Perspectiva de Desinstitucionalização Psiquiátrica; "Desospitalização Saneadora"; Implantação da Rede de Serviços de Atenção Psicossocial; Emergência das Associações de Usuários e Familiares: 1992-1995.

Esse período foi marcado por mudanças de histórias das políticas de saúde mental no Brasil, consolidando a perspectiva de desinstitucionalização psiquiátrica. Salientamos algumas mudanças ocorridas no período:

a) A II Conferência Nacional de Saúde Mental e os lançamentos de portarias ministeriais, a partir de 1991-1992, que estabeleceram a normatização e financiamentos para os novos serviços de saúde mental, particularmente de atenção psicossocial, e o processo rigoroso de controle e supervisão de melhoria da assistência dos hospitais psiquiátricos.

b) Paralelos ao processo de desospitalização, foram abertos, em todo o país, mais de 2.000 leitos psiquiátricos em hospitais gerais e cerca de 200 serviços de atenção psicossocial - hospitais-dia, Centro de Atenção Psicossocial (CAPS) e Núcleo de Atenção Psicossocial (NAPS) - . De acordo com um novo paradigma de atenção, a ser descrito, outros profissionais da área social e da saúde foram chamados a fazer parte da equipe de multiprofissionais mobilizados;

c) Houve um avanço da luta antimanicomial no plano legislativo, apesar da nãoaprovação do Projeto de Lei Paulo Delgado que previa a progressiva extinção dos manicômios e a sua substituição por recursos assistenciais na comunidade;

d) Um avanço significativo dos núcleos ligados ao movimento de luta antimanicomial durante o período, com congressos e encontros, difundiu-se por todo o país. Em 1996, as principais lideranças do movimento estimaram a formação de cerca de cinqüenta dessas associações em todo o país. A voz dos usuários e familiares deixa de ser apenas objeto 
de "escuta", ou interpretação terapêutica, com setting ${ }^{3}$ psicoterapêutico convencional, cidadãos a contribuir no processo de planejamento e execução de avaliação de serviços e política de saúde mental, e com perspectivas potenciais de atuarem até mesmo na formação de profissionais do campo.

$5^{\circ}$ Período: Limites à expansão da reforma psiquiátrica, tendo em vista as políticas neoliberais: 1995 .

a) Com a saída do Ministro da Saúde, Adib Jatene, no plano federal houve um bloqueio às tentativas de avanço da reforma de novas portarias de serviços e programas, como o Programa de Apoio à Desospitalização (PAD) e um relativo esvaziamento do papel da liderança política da coordenação de saúde mental, no Ministério da Saúde (MS).

Existe no legislativo um impasse com a aprovação, em 1998, pelo Senado, do projeto Substitutivo Sebastião Rocha que, se por um lado avança na direção de se afirmarem vários direitos dos usuários, por outro lado deixa uma brecha para a construção de novos hospitais psiquiátricos convencionais.

Em 1999, acontece a escolha da Dra. Ana Pitta, da USP, uma das lideranças do movimento para o cargo de direção dessa coordenação, e alguns avanços significativos foram conquistados: a legislação federal sobre as cooperativas sociais, para a inclusão no trabalho de indivíduos dependentes, e a portaria do MS sobre serviços residenciais terapêuticos.

b) Nas grandes cidades, o quadro econômico e social é marcado por um aumento significativo das taxas de desemprego, desfiliação social, miséria e os sinais de má qualidade de vida e de violência social, gerando aumento na incidência de estresses, ansiedades, fobias sociais, quadros da dependência química, dentre outros.

c) O sucesso do Programa de Saúde da Família, do MS, afirma a importância de cuidados com a saúde mental comunitária, possível de serem desenvolvidos pelo nível

\footnotetext{
${ }^{3}$ Cenário que compõe o atendimento terapêutico como local e horário das sessões.
} 
primário de atenção à saúde, além do sistema de referência e contra-referência a serviços psiquiátricos mais complexos, a partir da lógica comprometida com a desinstitucionalização psiquiátrica.

d) A emergência ou consolidação de governos de esquerda e centro-esquerda, em alguns Estados e municípios, significou uma difusão e/ou aprofundamento de programas de saúde mental comprometidos com a reforma.

e) O campo do complexo médico-industrial, da ciência, da corporação e das entidades profissionais em psiquiatria assiste ao avanço vertiginoso das abordagens voltadas aos fenômenos neuroquímicos e genéticos, com ampla difusão de técnicas de mapeamento cerebral e novos medicamentos, representando uma verdadeira onda de conservadorismo profissional.

A grande contribuição do movimento de desinstitucionalização ocorrido no Brasil tem sido a participação dos usuários dos serviços de saúde mental, seus familiares e os trabalhadores da área, na construção dos planos e projetos de intervenção nos manicômios e nas políticas públicas de saúde mental.

Portanto, a convivência de saberes no campo da saúde mental não visava a intervir na totalidade da vida social, como na proposta higienista. Objetivava, sim, primordialmente a mesma clientela que demandava serviços tradicionais de saúde mental, com ênfase naquela que procurava hospitais psiquiátricos, buscando compreender a loucura, envolvendo a complexidade da existência na diferença entre os indivíduos. Nesse sentido, buscava-se operacionalizar outros espaços sociais como CAPS e NAPS, comunidades terapêuticas, que favorecessem o desenvolvimento global do indivíduo no que tange habilidades, competências, socialização, equilíbrio emocional, ampliando, assim, seus movimentos e mudando a ótica de cura para tratamento mais humanizado e reabilitador. 
No cenário dos países latino-americanos, concomitante com a criação da Declaração de Caracas, da qual o Brasil participou, foi realizado um documento-síntese dessa conferência regional sobre a Reestruturação da Atenção Psiquiátrica para América Latina, realizada em Caracas em 1990 pela Organização Pan-Americana da Saúde (OPAS) e Organização Mundial da Saúde (OMS). Nesse documento todos os países participantes se responsabilizaram em diversificar e oferecer serviços de atenção comunitária, transformar o hospital psiquiátrico em espaço de tratamento e não de confinamento e, ainda, o compromisso de atualizarem a legislação de seus países para resguardarem os direitos humanos e civis das pessoas com transtornos mentais (OPAS/OMS, 1994).

Nas últimas décadas com a solidificação da Luta Antimanicomial, criaram-se hospitais-dia, NAPS e CAPS, pensões protegidas por todo o País, mas a prática asilar de internação psiquiátrica ainda se fazia presente.

Importante dizer que, no Brasil, as comunidades terapêuticas assumiram papel político que transpunha os asilos na busca de uma sociedade igualitária e democrática que se tornou impossível nos espaços públicos devido à invisibilidade social.

A relação interprofissional nas comunidades terapêuticas deu-se de forma horizontalizada, sem hierarquia definida que restringisse a participação de um profissional de alguma atividade. Essa importante experiência representou grande avanço para a Saúde Mental, com relação às experiências multiprofissionais dentro do hospital. É fundamental salientar a liberdade conferida aos usuários que passam a tomar decisões com relação ao seu tratamento.

Essa mudança pleiteada pela reforma psiquiátrica vai além da desconstrução dos manicômios - estrutura física - e passa pelas estruturas, presentes no interior de cada profissional e do sistema como um todo. Para tanto, é necessária uma revisão de valores e de 
condutas, normas, princípios e concepções tidas, por muitos até hoje, como corretas (PEREIRA, 2003).

A desinstitucionalização refere-se a uma reforma radical nos modos de pensar e agir de todos os envolvidos - técnicos, pacientes, familiares e comunidade - que tem como papel fundamental inserir o indivíduo portador de sofrimento psíquico no ambiente social.

Nesse sentido, a desinstitucionalização torna-se um processo que, ao mesmo tempo, busca a desconstrução do arcabouço teórico da psiquiatria e das práticas psiquiátricas e a invenção de maneiras de lidar com o portador de enfermidade mental (AMARANTE, 2003).

Nesse processo de mudanças a família passou a ser contemplada, como isso ocorreu?

\section{3 - Família: grupo primário do indivíduo}

Diante das mudanças, relatadas anteriormente, no que tange à transformação do modelo de tratamento em saúde mental, com o rompimento do paradigma saúde-cura, percebemos que a família ganha um espaço importante na reabilitação do enfermo psíquico.

A família, grupo primário e natural, participa no desenvolvimento humano das características sociais, éticas, morais e cívicas do indivíduo. É no seio familiar que o ser humano tem a capacidade de desenvolver laços afetivos mais profundos.

Costa (2003), em um estudo na vertente psicanalítica, buscou articular loucura, família e linguagem para compreender o sofrimento psíquico grave. Como conclusão de seu trabalho, pôde evidenciar que é pela linguagem que o ser humano estrutura seu mundo psíquico e também as diversas formas que estabelece a comunicação para ele interagir com o outro, com sua família, com a comunidade e com os amigos. Para ele, a família tem 
características de repetição, continuidade, espaço de construção de afetos e emoções humanas. Ressalta que, hoje, a família tem se configurado de diversas maneiras, desde a vinculação consangüínea até as novas formas de ser família, e ainda, com a substituição da família pelos vínculos sociais que possibilitam o sentimento de pertinência ao indivíduo.

A família seja qual for, tenha a configuração que tiver, é, e será, o meio relacional básico para as relações com o mundo, da norma à transgressão dela, da saúde à patologia, do amor ao ódio. Diríamos que deve prevalecer a tendência de que a família não é uma "relação obrigatória", mas antes uma dentre outras possibilidades que dão sentido ao ser humano (COSTA 2003, p. 87).

A família é um conceito amplo e imutável, porque sempre em transformação e nessa diversidade de expressões vinculares há múltiplas possibilidades de construção que podem ser de crescimento ou de sofrimento humano (COSTA, 2003). De acordo com Knobel (1996), o grupo familiar é o gérmen onde a vida se abriga e, acreditamos a célula-mãe da sociedade, nesse sentido pensá-la como mola propulsora na reabilitação do indivíduo portador de enfermidade psíquica faz-se eficaz e facilitadora desse processo.

É somente na década de 40, do século passado, na Europa e Estados Unidos, que a família se torna objeto de investigação. Na Europa, com intuito de compreender como as relações familiares interferiam no desenvolvimento e/ou reabilitação do enfermo psíquico, ela começou a ser estudada. Desde então muito se tem discutido sobre famílias e doença mental. Segundo Ponciano (1997), a terapia familiar sistêmica permite uma nova forma de compreender a doença mental, considerando não mais só o enfermo psíquico como estrutura de tratamento, mas todo o núcleo familiar a que o indivíduo pertence, considerando-o em dificuldade ou conflito que pode ser advindo da fragilidade das relações que ali se estabeleceram.

Vale ressaltar que aproximar a família ao serviço foi um grande avanço da assistência psiquiátrica. Nesse sentido, cada família é concebida como uma unidade em sua 
estrutura e dinâmica, mas não menos importante, favorecendo, assim, oferecer um atendimento que vislumbre a família como promotora e restauradora de sua própria dinâmica (MENEZES, 2001).

A família do portador de enfermidade psíquica, não raras vezes, é vista como um grupo onde existe algo que não vai bem, e um de seus membros externaliza o problema (a doença mental), não atingindo apenas um membro, mas o seu grupo. Nesse sentido, Costa (2003) enfatiza que a comunicação do indivíduo portador de sofrimento psíquico está prejudicada, por algum motivo ele não consegue ouvir e ser ouvido. As interações que estabelece com as pessoas ao seu redor estão deficientes.

Vale ressaltar que as transformações da família, ao longo dos últimos séculos, e, em conseqüência do ser humano, apontam para a necessidade de reorganização do direcionamento afetivo dos sujeitos humanos para diferentes e complexos sistemas de relacionamento, favorecendo que haja um maior intercâmbio relacional humano, levando a um aumento das experiências possíveis de subjetividade, bem como a uma intensificação da busca de satisfação, do prazer e da evolução em outras configurações vinculares (COSTA, 2003, p. 87).

Nesse sentido, esse autor propõe como caminho possível a diluição dos preconceitos e dos valores rígidos e tradicionalistas, para que o ser humano possa exercitar suas capacidades ainda não exploradas em face das limitações, repressões, construções de desvio e patologias que acabam por não corresponder ao seu desejo, na busca da felicidade e realização pessoal.

Portanto, a busca por mudanças no tratamento do usuário de saúde mental, com o advento das comunidades terapêuticas e inserção dos familiares, possibilitou a criação de um espaço aberto às reivindicações. Os familiares, em grande número, têm-se conscientizado da sua importância na recuperação do doente mental, porém, solicitam que as pessoas, os 
técnicos e os profissionais considerem suas dificuldades no trato com os mesmos e o ajudem a compreender, aceitar e lidar com a enfermidade mental.

Porém, é importante considerarmos que, ainda hoje em dia, muitas vezes os cuidados com o enfermo psíquico ficam a cargo e responsabilidade de uma única pessoa e quando isso acontece, há uma sobrecarga emocional e até física em cima dela. Reconhecer essa realidade abre caminhos para os profissionais que trabalham com saúde mental refletir sobre suas práticas e propor soluções inovadoras e eficientes, favorecendo maiores e melhores interações para esse indivíduo e sua família.

Portanto, abre-se um espaço para a discussão, a procura por serviços que atendam à nova demanda de pessoas que buscam tratamento mais inclusivo para sua enfermidade ou a de seu familiar, que respondam a essa nova demanda. Nessa perspectiva, é fundamental pensarmos sobre a reabilitação psicossocial.

\section{4 - Reabilitação psicossocial: a busca por um caminho}

Nesse cenário de lutas, reivindicações e conquistas, com discussões em vários âmbitos sobre a loucura, a doença mental e a psiquiatria, ocorre a criação de associações de pacientes e familiares que reivindicavam mudanças nas instituições manicomiais, exigindo transformação da assistência psiquiátrica em nosso país.

Para uma mudança efetiva no tratamento em saúde mental, é preciso que o modelo de Assistência Manicomial mude o foco, do dano que enfatiza a doença para um mais humanizado que compreenda o enfermo psíquico como ser humano.

O modelo psicossocial, como estratégia de tratamento, advém dos pressupostos da Reforma Sanitária, a partir de 1998, e da reforma psiquiátrica, com a descentralização do tratamento que propõe delegar ao município o gerenciamento de recursos e demandas para 
participação popular nas decisões, por meio dos conselhos e, ainda, a co-gestão dos sistemas de saúde (COSTA-ROSA, 2000).

Partimos da proposta de Basaglia que pressupõe uma visão de loucura e sofrimento psíquico como condição a ser aceita pela sociedade e tratada como tal, admitindo a pluralidade do indivíduo com suas diferenças no modo de ser, em um mesmo nível de sociabilidade, possibilitando o direito ao cuidado (AMARANTE, 2000).

Em vista disso, ressaltamos que, hoje, se por um lado ainda temos a percepção negativa acerca das pessoas portadoras de sofrimento psíquico e, porque não dizer, de suas famílias, por outro, convivemos com uma percepção mais humanizada a seu respeito que acredita nessas pessoas, valorizando-as como indivíduos capazes de crescer, de resolver seus problemas e de participar de sua comunidade.

Nesse sentido, a reabilitação psicossocial constitui um conjunto de programas e serviços que visam a assistir os portadores de sofrimento psíquico, severos e persistentes. $\mathrm{O}$ objetivo principal da reabilitação é restabelecer a autonomia individual para o exercício efetivo da cidadania ${ }^{4}$, ressaltando as qualidades dessas pessoas mediante uma abordagem compreensiva e global de suas demandas.

Saraceno (1999) chama nossa atenção quanto à cidadania do indivíduo portador de sofrimento psíquico não constituir a restituição de seus direitos formais, mas, sobretudo, a construção de seus direitos substanciais, e é dentro de tal construção - afetiva, relacional, material, habitacional, produtiva - que se encontra a única reabilitação possível.

Portanto, a reabilitação deve favorecer a desmontagem e a reconstrução da ideologia manicomial com seus contextos interativos patológicos visando à desinstitucionalização, o desenvolvimento de agentes sociais nos contextos de tempo e espaço móveis e, sem dúvida, a reativação de redes sociais de solidariedade e de justiça disponíveis.

\footnotetext{
${ }^{4}$ Entendemos cidadania como conjunto de direitos e deveres do cidadão, tem como eixo fundamental o direito da pessoa de ser diferente das demais e ser tratada com respeito e dignidade.
} 
Nesse sentido, pensar a reabilitação nos impulsiona a considerar os fatores que interferem nesse processo. Para Saraceno (2001), esse processo ocorre em dois níveis: um macro e outro micro. No micro, o foco é a relação estabelecida na afetividade e continuidade, enfim, refere-se ao real vínculo paciente-profissional e os investimentos nessa relação como tempo e energia gastos. No nível macro, tem-se o foco no serviço e sua organização como horário de funcionamento, estrutura aberta ou fechada para a comunidade, os recursos que utiliza são institucionais ou da comunidade ou, ainda, de ambos, se tem a aprovação de seus usuários e da comunidade e, por último, a satisfação desse serviço para os usuários e profissionais que ali trabalham.

Enfatizamos que o ponto fundamental da reabilitação é a construção da plena cidadania, favorecida pelo aumento da contratualidade em casa, no trabalho e na rede social. Saraceno (2001) instiga-nos a pensar a cidadania do portador de enfermidade psíquica, a partir desses três eixos, que acreditamos ser um processo contínuo com o intuito de criar condições reais do enfermo psíquico interagir em seu meio social. Pereira (2003) ressalta que os projetos atuais voltados para o modelo de reabilitação psicossocial têm enfoque em quatro aspectos: moradia, trabalho, família e criatividade (lúdica e artística).

A reabilitação é considerada uma abordagem de tratamento, mas deve ser considerada como estratégia que envolve não apenas o indivíduo enfermo, mas também o contexto em que vive, suas capacidades e habilidades, de maneira realista, incitando-nos a ver o indivíduo como um ser global reconhecido em sua especificidade e unicidade.

Para reabilitar, é preciso disponibilizar todas as possibilidades de tratamento. Nessa perspectiva, pensar a reabilitação psicossocial leva-nos a uma mudança de paradigma de tratamento-cura para o de tratamento-cuidado. Para Scatena (2000), essa mudança deve privilegiar o sujeito enfermo mental e não a doença e, assim, criar espaços para a inclusão e acolhimento apesar das diferenças. 
Defendemos o tratamento em saúde mental que favoreça o indivíduo e busque os recursos "escondidos" nele, o que pode ser favorecido pelo trabalho de Acompanhamento terapêutico (AT), com sua prática nômade que estimula a inserção do indivíduo nos serviços, na comunidade, enfim, no ambiente social.

A reabilitação coloca como pressuposto básico para atuação em saúde mental um olhar para a singularidade de cada caso, enfatizando as habilidades, necessidades e deficiências de cada um para, assim, ser possível pensar um projeto terapêutico individualizado.

Este projeto terapêutico tem como objetivo ampliar a rede social do indivíduo em sofrimento psíquico, aderi-lo ao tratamento, inseri-lo na comunidade, propiciar o contato entre ele e sua família de origem, resgatando assim sua história de vida, e, ainda, desenvolver habilidades e atividades remuneradas, se for o caso, buscando uma vida social com saúde.

A reabilitação psicossocial é constituída pelos conjuntos de meios, programas e serviços que são criados para facilitar a vida de pessoas com problemas severos e persistentes, buscando o maior nível de autonomia possível:

(....) em virtude da reabilitação psicossocial apontar para a redução do estigma e preconceito e visar promover a eqüidade e oportunidade, e seus proponentes estão empenhados na organização qualidade de cuidado e a garantia da vida, organização familiar e suporte auto-ajuda, participação educacional e promoção de esforços para fortalecer os serviços e pesquisa e desenvolvimento dos sistemas existentes. (HIRDES 2001, p. 66).

Ressaltamos, ainda, que não há um nível definido de autonomia a ser alcançado, pelo contrário, a busca pela autonomia é um processo em movimento constante e particular a cada indivíduo e entendida como um indicador de qualidade de vida.

Concordamos com Soares (2005) e Saraceno (1999) que a autonomia não pode ser condição para seleção de indivíduos portadores de sofrimento psíquico que receberam os cuidados em saúde. Ao contrário, todos devem ser olhados como seres singulares e seus 
projetos terapêuticos serem pensados partindo de suas potencialidades com o intuito principal de alcançar a maior autonomia possível.

Nesse sentido, salientamos que os projetos terapêuticos devem estabelecer metas desejáveis construídas em conjunto com o indivíduo a ser tratado, levando em conta seus interesses, desejos e expectativas e não serem traçadas considerando o foco dos técnicos.

Após o exposto, é preciso pensar alternativas para a reabilitação do paciente portador de sofrimento mental. Acreditamos que uma alternativa viável para possibilitar ampliação de movimentos desse indivíduo se dê pela sua inserção na comunidade, seja no espaço social, seja na manutenção da saúde e melhoria na qualidade de vida do indivíduo.

A qualidade de vida do ser humano precisa ser pensada para um indivíduocidadão inserido em seu ambiente e conhecido em seu contexto sociofamiliar; para isso, uma estratégia pode ser o Programa de Saúde da Família, que visa à assistência primária e secundária à saúde. Nessa perspectiva, torna-se um importante instrumento de reabilitação psicossocial.

No próximo capítulo discorreremos sobre o Programa de Saúde da Família, para instrumentalizar nossa reflexão. 
2 - PROGRAMA DE SAÚDE DA FAMíliA: estratégia de atendimento ao usuário de saúde 
Os modelos de atenção à saúde muito têm discutido, nas últimas décadas do século XX e início do século XXI, questões que colocam como condição para superação dos problemas de saúde o desenvolvimento social, econômico e pessoal e, também, a busca de alternativas que possibilitem a superação dos limites do modelo de saúde centrado na doença, na assistência curativa e na intervenção medicamentosa.

O Programa Saúde da Família (PSF) surge nessa perspectiva, criado no país, em sua atual concepção, na década de 1990. Foi inspirado em experiências advindas de outros países onde a Saúde Pública alcançou níveis interessantes de qualidade, com investimento na promoção da saúde e prevenção de doenças, como Cuba, Inglaterra e Canadá (VIANA \& DAL POZ, 1998). Insere-se no Programa Básico de Saúde como uma das estratégias possíveis que darão suporte a um programa assistencial. Tem como propósito melhorar a qualidade de vida dos indivíduos, atuando também em situações de risco, priorizando ações de prevenção, promoção e recuperação da saúde do indivíduo, de maneira integral e contínua. (BRASIL, 1998).

O PSF teve as linhas mestras no Programa de Agentes Comunitários de Saúde (PACS), desenvolvido, no Brasil, na década de 1990, no Ceará. Focaliza a família como unidade de ação programática de saúde, construindo as práticas de atendimento como, por exemplo, a noção de área de cobertura pelas famílias. Uma vez constituído, mostrou ser um modelo prático e inovador de ação preventiva em saúde, a partir do estabelecimento de interação com a comunidade e reorganização da demanda para a assistência à saúde (VIANA \& DAL POZ, 1998).

Concordamos com Levcovitz e Garrido (1996) que concebem o PSF como modelo de atenção à saúde da população como direito de todos os cidadãos, expresso na melhoria das condições de vida; com atendimentos mais resolutivos, integrais e principalmente humanizados. 
Podemos definir o PSF como: “(...) um modelo de assistência à saúde que vai desenvolver ações de promoção e proteção à saúde do indivíduo, da família e da comunidade, através de equipes de saúde, que farão o atendimento na unidade local de saúde e na comunidade, no nível de atenção primária”. (BRASIL, 1994, p. 6). Ancora-se em cinco campos centrais de ação: elaboração e implementação de políticas públicas saudáveis; criação de ambientes favoráveis à saúde; reforço da ação comunitária; desenvolvimento de habilidades pessoais e de orientação do sistema de saúde (DOMINGUES, 1998).

Além dessas características, a promoção da saúde estabelece-se na democratização, pluralização, diversificação e singularização de meios e fins principalmente porque incorpora objetos de vigilância mais amplos que as tradicionais notificações compulsórias como questões nutricionais, saúde ambiental, saúde mental, relações entre saúde e trabalho, violência entre outros (AYRES, 2004). Propõe, portanto, uma dinâmica diferente para a estruturação dos serviços de saúde, bem como para a sua relação com a comunidade, contemplando para isso diversos níveis de complexidade assistencial (SOUSA, 2000).

De acordo com Domingues (1998), o PSF deve contemplar alguns componentes ou requisitos:

- territorialização: cada equipe tem uma população definida com a qual se responsabilizará;

- $\quad$ inter-relação: com os serviços básicos, especializados e hospitais, em via de mão dupla, pela referência e contra-referência, garantindo assim completa atenção à saúde da população;

- atenção ativa: a equipe tem presença garantida na comunidade com as visitas domiciliares para identificar problemas e necessidades de saúde, buscar soluções em conjunto com as próprias famílias e a população e, ainda, orientar, informar e promover educação sanitária; 
- globalidade: as ações de saúde são voltadas para todos - crianças, adolescentes, homens, mulheres e idosos sadios ou não;

- continuidade: a equipe que acompanha a população é permanente, favorecendo assim a vinculação entre equipe de saúde e comunidade;

- participação: de todos na identificação de problemas, planejamento e controle das atividades dos serviços de saúde e na sua execução.

Portanto, esse modelo de assistência prioriza o ser humano pela universalidade da atenção, descentralização de decisões e atuação centrada em bases territoriais. Busca a humanização do serviço com o estabelecimento de um vínculo entre população e profissional de saúde, favorecendo assim maior acolhimento. Para Sousa (2000), esse modelo favorece a conscientização da população na busca e reconhecimento da saúde como direito de todos, pelas novas práticas de saúde.

É uma proposta de estruturação do modelo assistencial e tem como estratégia aprofundar os laços de compromissos e co-responsabilidades entre as autoridades sanitárias, as instituições, os profissionais e a comunidade (YUNES, 1998). Não com o intuito de responsabilizar, sozinho, o indivíduo ou a família, pela sua saúde, mas torná-la mais feliz, saudável e produtiva, a partir das ações combinadas entre todos os atores envolvidos.

O Programa de Saúde da Família é considerado como Modelo de Assistência à Saúde e como reorganizador e restaurador do Sistema Público de Saúde, entendendo-o como uma proposta que contempla as dimensões técnica, política e administrativa (VIANA \& DAL POZ, 1998). Esse modelo de saúde defende o investimento na comunicabilidade, articulação e integração entre os serviços especializados e aqueles que compõem a rede básica de saúde (BRÊDA et al. 2005).

O foco do PSF é na modificação positiva do modo de vida da população, pautado no controle dos fatores ambientais, sociais e naturais e na mudança do estilo e conduta de vida 
das pessoas com eliminação dos riscos e orientação de hábitos mais saudáveis com a incorporação de práticas preventivas, educativas e curativas próximas do cotidiano da comunidade atendida e atua, também, com ações nos grupos mais vulneráveis.

Portanto, tem grande impacto na diminuição da mortalidade e melhoria nas condições gerais de saúde da população. Almeida Filho (2001) acredita que é preciso estabelecer um tratamento não negativo ou residual em relação à doença, pois, além da promoção da qualidade de vida, o PSF intervém nos fatores que a colocam em risco, atuando assim na prevenção e não somente no tratamento da doença já instalada (SOUZA, 2004).

Cordeiro (1996) ressalta a eleição da família e seu espaço social como foco básico de atendimento e, ainda, a atenção integral ao indivíduo, já que os profissionais que atuam nesse programa precisam ter uma visão integral do ser humano, da família e da comunidade. Enfatizamos que é necessário ter conhecimento de todos os dispositivos de saúde, sociais e culturais, que a comunidade oferece com o objetivo de tratar, prevenir e incluir o indivíduo, ampliando suas possibilidades e recursos.

Nitschke (1991) diferencia o trabalho feito com o indivíduo e com a família. Para essa autora, o indivíduo tem um corpo, uma mente e uma individualidade e interage em um meio cultural. A família, por outro lado, é única, mas tem uma composição social, uma rede de interações com uma estrutura de funcionamento com papéis preestabelecidos; possui objetivos e decide enquanto grupo. De acordo com Souza (2004), qualquer situação que envolva o processo saúde/doença de algum membro da família, de algum modo, interferirá nas relações de seus membros.

Para trabalhar com famílias é preciso compreender suas interações, revisar a postura do profissional, estar aberto para discussão, compartilhar e negociar, não somente com os pacientes, outros familiares, mas também, com os colegas da equipe profissional que 
atende essas famílias, já que o trabalho com famílias necessita de um enfoque multidisciplinar (NITSCHKE, 1999).

De acordo com Yunes (1998) o PSF tem fundamental papel também como porta de entrada do Sistema de Saúde com um poder indutor no reordenamento dos demais níveis de atenção, intermediando os serviços existentes no município e região, quando é o caso, favorecendo maior agilidade e menor custo para os cofres públicos.

Acreditamos que pensar o usuário como cidadão de direitos e deveres favorece práticas em saúde que disponibilizam atendimento e objetivam o comprometimento do indivíduo em seu tratamento, desde tomar decisão pelos procedimentos a serem realizados em seu corpo, necessários para o restabelecimento de sua saúde, até a participação em práticas saudáveis de vida, que vão da alimentação a hábitos de higiene, propicia o comprometimento do indivíduo consigo mesmo, com sua família, com seu ambiente e com a comunidade em que está inserido.

O PSF se insere numa proposta que busca um modelo de atenção à saúde que a reconhece como um direito de cidadania, com melhoria nas condições de vida e, para tanto, oferece à comunidade serviços integrais e humanizados que dão conta de resolver seus problemas. Subsidia a participação da comunidade nas ações de saúde e no controle social, já que seu norte é trabalhar práticas de saúde que gerem integração entre ações individuais e coletivas.

Para Campos (1992), a vinculação do indivíduo e do seu grupo familiar à equipe de saúde favorece o aumento da eficácia das ações de saúde e um controle social mais efetivo pela própria população que recebe o atendimento.

Sousa (2000) amplia essa visão, quando esclarece que a vinculação do profissional de saúde com a população atendida proporciona uma visão sistêmica e integral do indivíduo em seu contexto familiar e social, o que favorece o desenvolvimento de ações de 
promoção, diagnóstico precoce, recuperação da saúde e de reabilitação, provocando uma redução do dano causado pela experiência da doença.

O PSF tem como base uma equipe inter e multiprofissional (médico, enfermeiro, auxiliar de enfermagem e agente comunitário de saúde) que atua na área de abrangência da unidade ambulatorial à qual a equipe está vinculada (BRASIL, 2000). O foco desse programa está na equipe e não no médico, como no modelo biologicista centrado no médico e na doença, pressupondo, assim, mudança na relação profissional de saúde e usuários.

Espera-se que o profissional do PSF atue com criatividade e senso crítico mediado por uma prática humanizada, centrada na promoção, prevenção, recuperação da saúde e reabilitação, frente às possibilidades que o meio em que o indivíduo vive permite, favorecendo intercâmbios entre os diversos dispositivos que a cidade oferece para aumentar a qualidade de vida do ser humano.

Um outro aspecto do PSF é conceber o agente comunitário como membro daquela comunidade. Além de conhecer as pessoas, os hábitos e costumes daquele grupo, porque faz parte do mesmo, o agente comunitário facilita uma inserção de maior proximidade e vinculação com ele, favorece orientação e educação para a saúde, promovendo uma melhor qualidade de vida para a comunidade.

Esse agente de saúde é o representante instituído do saber popular promovendo o elo entre os técnicos de saúde e a comunidade, não está preso a nenhum saber técnico e assim pode olhar para a dor e o sofrimento do paciente sem os rótulos usuais da equipe de técnicos: de cura, prescrição, solução. Fortuna (2003) acredita que esse profissional transversaliza ${ }^{5}$ a equipe de técnicos. Concordamos com Lunardelo (2004) que acredita que o agente, como morador daquela região, vivencia situações semelhantes aos usuários da saúde daquela

\footnotetext{
${ }^{5}$ Transversalidade, para Guatarri (1993), é a dimensão que se propõe a superar os impasses - de um lado, a pura verticalidade e, de outro, uma simples horizontalidade -, favorecendo uma comunicação máxima entre os diferentes níveis e, sobretudo, nos diferentes sentidos.
} 
comunidade e, assim, identifica-se com as condições de vida daquele grupo, favorecendo sua abordagem e interação com eles.

\section{1 - A Saúde Mental no Programa de Saúde da Família: compassos e descompassos}

Nesse sentido os cuidados em saúde mental ficam sob a responsabilidade de toda a equipe, mesmo que não tenha preparo especializado, treinamento ou capacitação para realizar tal atividade.

Para melhor compreender a realidade da saúde mental no universo do PSF, buscamos subsídios em alguns autores que viveram experiências que podem contribuir para nossas reflexões, como Lancetti (s/d a), Cabral et al. (s/d), Rosa (2002), Brêda et al. (2005).

Lancetti (s/d a) traz um compilado de experiências em diferentes regiões do país que tentam integralizar saúde mental e Saúde da Família. Há experiências nos Estados de São Paulo, Pernambuco, Minas Gerais e Ceará em que seus protagonistas mostraram comprometimento com a Reforma da Atenção Psiquiátrica, com a sociedade e os princípios do Sistema Único de Saúde (SUS).

Para cumprir tal intento, é necessário construir práticas que viabilizem a transformação da cultura em torno do processo saúde/doença e da loucura, favorecendo uma convivência mais saudável com as diferenças (CABRAL et al. s/d).

Essa mudança de concepção é tarefa árdua. Além da disponibilidade dos profissionais, Lancetti ( $\mathrm{s} / \mathrm{d}$ b) elenca características que favoreceram o sucesso das experiências de Bauru (1984 - 1986) e Santos (1989 - 1996): velocidade, diversidade, ousadia, criatividade e eficácia nas ações. 
Rosa (2002), focando seu olhar no enfermeiro do PSF, percebeu que a formação curativa e individualista desses profissionais dificulta a compreensão deles para as questões da reforma psiquiátrica e da reinserção do enfermo psíquico na família e na comunidade.

O espaço e a oportunidade ímpar para uma forma nova de agir em saúde aliados à mudança do modelo médico-privatista para um novo modelo, a ampliação da participação e controle social, a oportunidade de reduzir o uso de tecnologias no atendimento em saúde e a valorização da escuta, do acolhimento e do vínculo (BRÊDA et al. 2005) são fatores que favorecem o PSF como espaço para a reabilitação do portador de sofrimento mental.

O inusitado e o imprevisível constituíram marcas na experiência da saúde mental no PSF (CABRAL et al. s/d). A escuta favoreceu a aderência no Projeto Qualis/PSF (LANCETTI, s/d b). E, ainda, a resolutividade proporcionada pela grande articulação com os outros setores, buscando resolver problemas em saúde mental (LANCETTI, s/d a).

O suporte técnico para os profissionais dos Programas de Saúde da Família, assim como treinamentos e orientações, favoreceram maior eficiência e eficácia do serviço a este tipo de demanda, propiciando maior vinculação e acolhimento aos portadores de sofrimento psíquico e suas famílias (OLIVEIRA et al. (2004), bem como com a comunidade atendida pelo serviço.

Entre as dificuldades que alguns programas tiveram acentuam-se: a soberania médica (LANCETTI, s/d b), a cultura manicomial arraigada (SAMPAIO e BARROSO, s/d) e, ainda, o receio que alguns membros da equipe de saúde da família sentiram com o desconhecimento sobre como lidar com pessoas marginalizadas socialmente (CRUZ, s/d), como são os indivíduos diferentes, seja por causa da patologia mental, seja pela exclusão que a pobreza propicia.

Lancetti (s/d b) elenca algumas características desse Programa: 
1 - Faz-se um cadastramento de todos os membros da família atendida e de todos os moradores da área. Os atendimentos são feitos segundo o critério da necessidade e não da demanda, o que favorece o direito do indivíduo, estimulando a cidadania;

2 - A pessoa e o grupo familiar são conhecidos pelo nome e por sua história e também há a referência dos profissionais que os atendem, o que propicia singularidade;

3 - Tem como imperativo resolver o máximo de problemas na região, favorecendo a continuidade do atendimento e evitando o encaminhamento desnecessário, fortalecendo o vínculo equipe/usuário;

4 - Promove ações coletivas de saúde;

5 - Realiza atendimentos centralizados na equipe, e não apenas no médico.

O PSF trabalha prioritariamente práticas de promoção da saúde e prevenção da doença, visando ao indivíduo saudável e participante de sua comunidade. Essa forma de atendimento favorece a construção de redes com maior e melhor relacionamento equipe/usuário. Para que isso ocorra corroboramos com Fortuna (2003) que enfatiza a necessidade de fazer pactos de trabalho pela vida e para a vida, pactos com o devir que maximizam as possibilidades e não aprisionam.

O trabalho visando promoção de saúde, com enfoque em uma equipe multidisciplinar e que valorize o bem-estar e uma vida com qualidade, precisa contemplar a saúde mental da população.

Para pensarmos o tratamento em saúde mental, expusemos os pressupostos básicos da Reforma Psiquiátrica, da Reabilitação Psicossocial e do Programa de Saúde da Família. Passaremos agora aos pressupostos do Acompanhamento Terapêutico para subsidiar este trabalho. 
3 - ACOMPANHAMENTO TERAPÊUTICO: a busca por novas terapêuticas para o tratamento em Saúde Mental 
Falar do Acompanhamento Terapêutico (AT) nos remete à história da loucura e à busca por novas terapêuticas para o tratamento em saúde mental. É terapêutica inovadora, por ser diferente da proposta de tratamento pelo uso de medicação psicotrópica e da internação psiquiátrica com confinamento e castigo para o enfermo e, também, porque se insere no ambiente do indivíduo, favorecendo o seu resgate do enclausuramento a partir do seu ambiente. Para refletir sobre essa terapêutica, discorreremos sobre sua criação e desenvolvimento.

O AT surgiu como uma proposta terapêutica quando outras não eram possíveis ou recomendadas; uma alternativa ao modelo asilar de tratamento a pacientes psiquiátricos, visando à reinserção social e à reintegração familiar.

Originou-se na década de 1970, em Buenos Aires. Tem como proposta de atendimento múltiplo ao indivíduo por uma equipe especializada. O foco do trabalho eram pacientes severamente perturbados e, em geral, que procuravam o serviço em situações de crise (MAUER e RESNIZKY, 1987).

Nos dizeres de Mauer e Resnizky (1987), após a aceitação do tratamento pelo cliente e por sua família, o profissional responsável pelo caso fazia a proposta de terapia em abordagem múltipla. $\mathrm{O}$ foco do atendimento são todos os aspectos de sua vida; para isso, alguém da equipe terapêutica - profissional de referência, quando possível - participa dos grupos dos quais o cliente faz parte, conhecendo-o e aprofundando os vínculos com ele. Essa abordagem possibilita compreender as relações que o indivíduo estabelece em seu meio, bem como conhecer a interação familiar.

A equipe múltipla é composta por um terapeuta responsável pelo acompanhamento familiar, um médico, um terapeuta individual e um ou mais acompanhantes terapêuticos (at), conforme a necessidade do caso, sendo de fundamental importância a comunicação entre todos os integrantes da equipe, pela veiculação de informações que 
neutraliza as tentativas de manipulação psicopática e os pactos perversos que cliente e familiares podem induzir ao longo dos atendimentos.

Nessa perspectiva, na Europa, havia vários movimentos, ocorrendo que influenciaram o aparecimento do atendimento múltiplo ao paciente: o movimento antipsiquiátrico inglês, a psiquiatria democrática italiana e a psicoterapia institucional francesa.

Esses movimentos criaram os auxiliares psiquiátricos que passaram a ser chamados de "amigo qualificado" e, posteriormente, de "acompanhante terapêutico". (BARRETO, 1998).

No Brasil, a idéia do auxiliar psiquiátrico passou pela clínica Pinel (Porto Alegre), por comunidades terapêuticas (Rio de Janeiro) e pelo Hospital-dia "A Casa” (São Paulo). O trabalho dos auxiliares psiquiátricos era proposto por terapeutas e familiares, como alternativa à internação e um recurso a mais para o tratamento (BARRETO, 1998).

O AT se configura como tratamento, quando as abordagens clássicas não são recomendadas ou não favorecem o tratamento do cliente e, ainda, quando há sofrimento que cause exclusão, impedindo o indivíduo de participar do seu meio social e incapacidade para organizar sua vida cotidiana com acesso a trabalho, estudo e/ou atividades de lazer.

O trabalho do at não ocorre de maneira isolada; insere-se em uma equipe de trabalho ou, pelo menos, com um médico psiquiatra. Pode ocorrer desde o início do tratamento ou pode ser um agente em um processo de mudança, em uma crise psicótica ou até mesmo em situação específica, focal, que o indivíduo não consegue resolver sozinho.

Acompanhante terapêutico e medicação interagem no tratamento, ajudando o acompanhado a viver um nível de angústia que lhe seja suportável, permitindo, assim, interagir consigo mesmo - com seus pensamentos, seus sentimentos, suas emoções e também com as pessoas com quem se relaciona (MAUER e RESNIZKY, 1987). 
Esse profissional $^{6}$ deve ser capaz de estar junto com o paciente, buscando resgatálo de seu mundo particular, o que pressupõe ter capacidade para contar, acolher, acompanhar e refletir com o paciente sobre suas ações (BARRETO, 1998; MAUER e RESNIZKY, 1987). Além disso, vale lembrar que há várias emoções que acompanhante e acompanhado compartilham, como alegria, tristeza, ternura e angústia.

O AT é uma prática terapêutica caracterizada pelo atendimento ao cliente in loco, o que pode ocorrer em sua própria casa, como também nos vários lugares que a cidade oferece, como praças, shoppings, bares, etc., sendo o setting construído pelo acompanhante terapêutico no momento.

Os atendimentos são feitos fora da clínica ou dos locais tradicionais de tratamento. Seu lugar é a cidade e o que ela oferece. Nas palavras de Porto e Sereno (1991, p. 24): “(...) ao estarmos na rua com um paciente, estamos tratando no lugar mais distante e mais descentrado das estruturas psis (psiquiatrizantes) de tratamento o que nos coloca muito próximos do semlugar da psicose (...)".

$\mathrm{O}$ at, além de ver o doente mental como um sujeito que tem condições de estabelecer relações, possibilita a mediação do indivíduo com o mundo, evitando a segregação e o isolamento do paciente. É um recurso que favorece a circulação do indivíduo no espaço social. Marques (1991) ressalva que estar no ambiente social não garante ao indivíduo ser no social, mas incita a sua percepção que não é, à medida que reconhece aqueles que são. Essa mobilidade que o AT representa, com sua transitoriedade, pelos mais diversos ambientes, permite alcançar o sujeito onde ele está e resgatá-lo, e assim, possibilitar-lhe (re)significações para sua existência.

\footnotetext{
${ }^{6} \mathrm{O}$ acompanhante terapêutico costuma ser uma atividade clínica desenvolvida por qualquer profissional com formação superior em áreas da saúde. Freqüentemente temos muitos psicólogos exercendo essa atividade, sem contudo, ser uma atividade exclusiva dele.
} 
Nos dizeres de Beltrão (2002), “acompanhar é acreditar em possibilidades, mesmo quando se diz que ali não há mais nada a fazer", principalmente porque o acompanhante terapêutico compõe a equipe quando outros recursos terapêuticos já foram tentados.

Palombini (2004) refere à prática do AT a partir de seu trabalho de supervisão de at no serviço público, para isso relata acompanhamentos realizados no Programa de Acompanhamento Terapêutico na rede Pública do Instituto de Psicologia da Universidade Federal do Rio Grande do Sul. Nesse trabalho, pôde perceber o AT como um aliado importante no serviço público, confirmando nossa percepção de que casos indicados para AT são, em grande maioria, clientes que a equipe não sabia o que fazer ou sentia-se impotente ou, ainda, aquele cliente que resistia em aceitar o tratamento proposto. Enfim, a equipe encaminhava porque todos os outros recursos terapêuticos já tinham sido tentados, porém sem sucesso. Um outro indicativo para AT, de acordo com essa autora, é o caso contrário, quando o paciente tem um prognóstico favorável, responde bem ao tratamento e o at atua como potencializador, fazendo um trabalho pontual nesse processo.

Acompanhar, muitas vezes, torna-se suportar a errância, o desconhecido, o inabitado (CHNAIDERMAN, 2004), requer disposição interna para acolher o outro, buscando compreendê-lo em sua singularidade nem sempre perceptível, com o intuito de alcançar um lugar que possibilite contato, comunicação que viabilizem, enfim, um campo de trocas. Essa comunicação pode ser a partir do corpo: os gestos, tom de voz, postura que favorece o at a compreender como o acompanhado se expressa no mundo, na sua vida (PITIA, 2002).

$\mathrm{O}$ at favorece o enriquecimento do espaço terapêutico à medida que se desprende das amarras institucionais e se lança no contexto do cotidiano possibilitando, mais do que redução de sinais e sintomas, um ganho ou melhora em seu estado geral, bem como maior adaptação e interação em seu meio (PALOMBINI, 1998), identificando recursos e talentos, habilidade e estratégias de sobrevivência tanto no âmbito familiar como no da instituição que 
o favorece (CAMARGO, 1991). Esse olhar é diferenciado do restante da equipe, é um olhar que vai além de sua rotina, de suas capacidades e incapacidades, um olhar como quem vê com uma lupa que, assim como amplia a visão de quem olha, aumenta as possibilidades do sujeito.

O AT pode ser usado para possibilitar novos olhares sobre o cliente, em uma tentativa de incentivar descobertas e (re)criar dispositivos que possam divulgar para as pessoas que participam dos processos do acompanhado (familiares, colegas, amigos e equipe terapêutica.), e para o próprio sujeito, já que o mesmo é um sujeito em sua história.

Cenamo et al. (1991) definem como funções do at:

1. Função de ego auxiliar: é um "empréstimo" do ego do acompanhante terapêutico ao paciente, com o intuito de um fortalecimento do ego do acompanhado. Trabalha-se no nível das funções egóicas, uma vez que o acompanhar implica "pensar junto", uma ajuda na percepção da realidade interna e externa por parte do paciente, visando a uma melhor adequação à realidade.

2. Função de modelo de identificação: o acompanhante terapêutico favorece a identificação do paciente com modelos mais saudáveis de atuar no mundo e, ainda, permite que o paciente projete e reconheça nele o que deseja desenvolver ou ser.

3. Função de aliviar as ansiedades persecutórias: esta função é exercida pelas atitudes interpretativas intrínsecas a cada tarefa, via modelo de identificação, principalmente porque ele representa o terapeuta, na ausência deste.

4. Função de agente socializador: atenuando o distanciamento do indivíduo em sofrimento mental do mundo real, facilitando-lhe o reencontro com esse mundo de forma paulatina e dosada com o todo perdido.

5. Função de servir como catalisador das relações familiares: facilitando ou mesmo promovendo as relações do paciente com seus familiares. 
6. Função de interlocutor dos desejos e fantasias do paciente: o acompanhante terapêutico deixa de agir na esfera da necessidade e penetra na esfera do desejo, deixando de ser apenas ego auxiliar. A predominância desta função seria um indicador para a finalização do acompanhamento.

Mauer e Resnizky (1987) descrevem também como funções do at:

7. Perceber, reforçar e desenvolver a capacidade criativa do paciente: estimulando o desenvolvimento das áreas mais organizadas de seu ser, em detrimento de seus aspectos mais desajustados.

8. Informar sobre o mundo objetivo do paciente: dispondo de muito tempo com o acompanhado, ele poderá conhecer e informar a equipe sobre o comportamento no cotidiano e vinculação com os familiares, favorecendo assim uma compreensão global dele e, conseqüentemente, condutas mais qualificadas da equipe que o atende.

Sua função vai além do ouvir; passa por possibilitar diálogo do paciente com a família, com a equipe terapêutica, transitar pelo social, assim como criar novas situações que permitam o contato com a realidade, buscando a (re)conexão do paciente com o outro e com o mundo, criando e ampliando "redes" de relacionamento, usando, para isso, recursos teóricos e práticos do profissional e outros recursos que a própria cidade oferece.

Carvalho (2004) cita algumas características que delineiam a clínica do AT: atuação no cotidiano com setting variado e situações inusitadas como encontros inesperados com pessoas do círculo de relacionamento do acompanhado ou do acompanhante que exigem manejo adequado por parte do acompanhante, ou então, a vivência de momentos da intimidade do acompanhado e sua família. Essa autora cita ainda que o número de horas de trabalho do AT costuma ser superior aos da psicoterapia, sendo que o at atua, muitas vezes, como articulador entre as pessoas da rede social do acompanhado e ressalta também a 
necessidade do acompanhante fazer parte de uma equipe que não só esteja diretamente ligada ao paciente como também indiretamente.

Essa clínica objetiva tratar o indivíduo dando sentido às suas vivências e (re) construindo sua história pessoal, como podemos ver nas palavras de Porto e Sereno (1991, p. 24) “(...) tentar delimitar uma terapêutica que leva em conta o modo em que o louco é contextualizado historicamente pelo imaginário social, para compor, inclusive, a história pessoal perdida pelo psicótico".

O acompanhante busca aumentar a adaptação do indivíduo, além de ajudar a desenvolver novas maneiras de atuar no mundo. Isso será feito ao longo da convivência com o paciente, mostrando-lhe, por exemplo, que frente a uma situação determinada há possibilidades de reagir de várias maneiras, exercitando assim a flexibilidade sem, no entanto, ser diretivo e sistemático. Ressaltamos que o intuito primordial dessas ações não é o assistencialismo e, sim, ações terapêuticas que visam à reabilitação do indivíduo.

Esse profissional vai tecendo, circulando, produzindo obras em conjunto, fortalecendo vínculos, revendo limitações e limites, enfim, recriando espaços. Desafio constante contra as idéias ainda presentes em nossa sociedade, de que nada há a ser feito.

O AT é uma prática terapêutica que, além do exposto acima, trabalha a diferença, seja da psicose, seja de qualquer enfermidade que exponha o cliente a uma condição de sem lugar estabelecido e, assim, favorece a inclusão dessa pessoa no seu ambiente. Nesse sentido, o at possibilita encontro desse ser humano consigo mesmo e com o outro.

Atualmente, a prática do AT ganhou maior dimensão, possibilitando intervenções, além das psicoses, na deficiência mental ou física, em casos de acidentados que necessitem de apoio domiciliar especializado, terceira idade e, principalmente, em casos onde há uma recusa e/ou contra-indicação de um trabalho terapêutico no consultório. 
Após as considerações expostas, abordaremos para o leitor os objetivos e o norte desta pesquisa, com a metodologia utilizada e o referencial teórico de Martin Heidegger que subsidiará nossa compreensão do fenômeno do atendimento terapêutico como tratamento ao indivíduo portador de sofrimento psíquico, inserido em um Programa de Saúde da Família.

\section{1 - OBJETIVOS}

O objetivo principal deste trabalho foi conhecer a percepção e os que pacientes com sofrimento psíquico, seus familiares e os agentes comunitários têm do Acompanhamento Terapêutico para tratamento em saúde mental. 
4 - METODOLOGIA: compreendendo o processo da pesquisa 
Para compreender a percepção e os sentidos atribuídos ao Acompanhamento Terapêutico pelos clientes, seus familiares e os agentes de saúde, no tratamento do enfermo mental, buscamos, na metodologia fenomenológica embasada nas idéias de Martin Heidegger $^{7}$, o caminho para trilhar e cumprir nosso intento. Porém, antes de prosseguir no pensamento heideggeriano, faremos uma reflexão dos fundamentos da Fenomenologia para facilitar esta jornada.

Heidegger busca conhecer o próprio homem enquanto ser existente e, para isso, utiliza a reflexão fenomenológica que defende um conhecimento das coisas que se mostram em si mesmas. Para esse autor, a fenomenologia é transcendental porque é essencialmente possibilidade, como vemos em suas palavras: “A compreensão da Fenomenologia depende unicamente de apreendê-la como possibilidade" (HEIDEGGER, 1988, p. 71).

A Fenomenologia, enquanto metodologia de pesquisa, centra sua atenção no sentido que o fenômeno, que buscamos conhecer, tem para o indivíduo que vivencia tal fenômeno. Para Heidegger (1988), é ver por meio do que se mostra, tal como é por si mesmo.

Nessa perspectiva, a Fenomenologia, com o conceito da intencionalidade ${ }^{8}$ da consciência, possibilita-nos pensar numa relação de sujeito e objeto, de forma diferente, não havendo dicotomia sujeito - objeto. Desse modo, a consciência está vinculada a um mundo que a percebe, portanto, não como "consciência pura", pois quem atribui significados ao objeto é o sujeito. Gilles (1975) e Dartigues (2005) concordam que o método fenomenológico não procura explicar ou buscar a verdade do que se está pesquisando, mas sim o significado e o sentido do fenômeno, que busca compreender, por quem o está vivenciando, ou seja,

\footnotetext{
${ }^{7}$ Filósofo alemão (1989 - 1976) nasceu no sul da Alemanha. Formou-se na Universidade de Freiburg, em Breisgon, onde estudou, com Edmund Husserl, o método fenomenológico.

${ }^{8}$ Segundo Brentano, "a intencionalidade é o caráter específico dos fenômenos psíquicos enquanto se referem, todos eles, a um objeto imanente. Brentano baseia a classificação dos fenômenos psíquicos nas diversas formas de intencionalidade. A representação, o juízo e o sentimento, que são precisamente as três classes fundamentais de tais fenômenos, distinguem-se entre si pela natureza do ato intencional que os constituem" (Abbagnamo, 1978, p. 79).
} 
objetiva analisar as vivências intencionais da consciência para perceber como se dá o sentido dos fenômenos para essa consciência.

Critelli (1996) ressalta que a fenomenologia preocupa-se com o sentido do ser, mas partindo da premissa de que qualquer conhecimento a esse respeito é sempre relativo e provisório.

A Fenomenologia surge a partir do legado husserliano, é considerada como uma corrente filosófica e, também, como um método que possibilita uma reflexão existencialista. De acordo com Martins e Bicudo (2006), ela procura enfocar o fenômeno que se manifesta, ou seja, as experiências vividas e os significados que quem as vivencia lhes atribui, portanto, centra-se na relação sujeito - objeto - mundo.

Dessa forma, essa abordagem teórica focaliza a experiência vivida e sua significação de como ela se apresenta na consciência. A atenção se volta para o específico, o peculiar, buscando a compreensão particular do que visamos conhecer e não a explicação dos fenômenos estudados. Para Dartigues (2005), a fenomenologia propõe uma reflexão sobre a coisa em si, sem desconsiderar o mundo exterior e o sujeito consciente, inserido nele.

Para tanto, trabalhamos com o fenômeno situado e circunscrito na vivência do indivíduo, buscando compreendê-lo a partir do relato dessa experiência, trazido pelo sujeito que vivencia determinada situação. É, portanto, através do discurso do sujeito que é feita uma aproximação com a essência do fenômeno.

Assim, a pesquisa na abordagem fenomenológica tem início com uma interrogação do pesquisador em relação ao fenômeno, e essa interrogação conduzirá o pesquisador até chegar à essência do fenômeno interrogado. Segundo Critelli (1996), a interrogação é determinada por aquilo que se quer saber. Ela situa-se numa região de inquérito, ou seja, está situada no mundo-vida desses sujeitos. 
Como modalidade de pesquisa, a fenomenologia trabalha na perspectiva de investigar diretamente as vivências humanas, sem se prender a explicações ou a generalizações, uma vez que o objetivo dessa abordagem de pesquisa é a descrição do fenômeno, para assim vir a compreendê-lo e chegar à sua essência. E isso se dá a partir do indivíduo que está vivenciando tal fenômeno. Nesta pesquisa se expressa por três indagações: “Como você percebe a atuação do Acompanhamento Terapêutico no seu tratamento?”, para os colaboradores-clientes; "Como você percebe a atuação do Acompanhamento Terapêutico no tratamento do seu familiar?", apresentada para os colaboradores-familiares; e, "Como você percebe a atuação do Acompanhamento Terapêutico no tratamento de pacientes portadores de enfermidade psíquica?" Essas questões dirigiram nossa atenção para o tratamento em saúde mental e a reabilitação psicossocial, ou seja, para a percepção e os sentidos que os colaboradores-clientes, seus familiares e os agentes comunitários atribuem à presença do at ou à prática do Acompanhamento Terapêutico no tratamento do indivíduo portador de sofrimento psíquico.

Para chegarmos à essência desse fenômeno, é preciso suspender todos os valores e conhecimentos prévios do pesquisador, ou seja, colocar entre parênteses todas as informações e conhecimentos que temos a priori acerca do fenômeno que buscamos conhecer para que, assim, possamos vê-lo como se apresenta; em outras palavras, colocando-o em evidência, para que se manifeste por si mesmo. É o momento da redução fenomenológica, como vemos abaixo:

A redução fenomenológica consiste em retornar ao mundo da vida, tal qual aparece antes de qualquer alteração produzida por sistemas filosóficos, teorias científicas ou preconceitos do sujeito, retornar à experiência vivida e sobre ela fazer uma profunda reflexão que permita chegar à essência do conhecimento, ou ao modo de como este é constituído no próprio existir humano (FORGHIERI, 1993, p. 59). 
Vale ressaltar que a verdade que se busca compreender ocorre na intersubjetividade do pesquisador-sujeito. Mesmo pondo em suspensão os seus valores, o pesquisador participa do mundo do cliente enquanto acompanhante terapêutico, o que é uma referência em sua vida, norteando sua busca e interpretação do fenômeno que busca conhecer. São duas as verdades, a do acompanhante terapêutico e a do indivíduo.

Com a postura do fenomenólogo, que coloca em suspensão os preconceitos, conhecimentos prévios ou julgamento, o pesquisador parte para reconhecer os momentos significativos do discurso, distinguindo-os daqueles que não são.

Segundo Martins e Bicudo (2005), a partir dos relatos dos informantes, obtidos por meio da entrevista, têm as descrições e, assim, o pesquisador, imbuído da postura fenomenológica, pode apreender a experiência vivenciada, bem como os significados atribuídos a ela pelo próprio sujeito. Essas descrições são o primeiro movimento para abordar o fenômeno que se quer conhecer, que nesta pesquisa se constitui pelos significados atribuídos ao acompanhante terapêutico, como instrumento terapêutico no tratamento em saúde mental, pelo portador de sofrimento psíquico, seus familiares e o agente comunitário que o atende. Esses significados atribuídos ao at nos possibilitarão conhecer as unidades de significado para, assim, compreendermos o fenômeno interrogado à luz da Psicologia. A importância dessas descrições está na explicitação que se faz da percepção do mundo-vida dos sujeitos.

Nos dizeres de Martins e Bicudo (2005) há quatro momentos para a análise fenomenológica, que descreveremos abaixo:

Primeiro momento: são realizadas as transcrições dos relatos dos entrevistados; posteriormente, é feita uma leitura atenta e integral das falas dos entrevistados sem se ater, identificar ou interpretar qualquer elemento contido no texto, com o intuito de apreender o sentido geral, o todo. 
Segundo momento: o pesquisador parte agora para uma releitura das descrições para, assim, abstrair as unidades de significado que não estão prontas ou "fechadas" no texto, mas que serão apreendidas pelo pesquisador que busca compreender e interpretar os significados atribuídos ao fenômeno ora indagado para, desse modo, poder construir as categorias pelas convergências e/ou divergências encontradas nas falas dos sujeitos.

Terceiro momento: com as unidades de significado já discriminadas, o pesquisador passa a agrupá-las em categorias, transferindo-as de relatos dos entrevistados para o seu discurso psicológico, quando busca a compreensão da vivência do informante à luz da fenomenologia. Os autores propõem, para isso, a reflexão e a variação imaginativa, que são todas as variações possíveis a respeito do conteúdo lido.

Quarto momento: é o momento da compreensão-interpretação fenomenológica a partir das categorias que emergiram do discurso dos entrevistados, para se chegar a uma descrição da estrutura psicológica do fenômeno interrogado. Nessa fase da pesquisa, chegamos aos significados da experiência vivida que descrevemos e reduzimos, para que o material seja organizado e ressignificado, de acordo com suas convergências e divergências, possibilitando a compreensão do fenômeno indagado.

É importante ressaltar que para essa análise, o pesquisador realiza uma redução fenomenológica. Na visão de Forghieri (1993), a redução fenomenológica ocorre em dois momentos: o "envolvimento existencial", em que o pesquisador penetra na situação que vai pesquisar, para chegar ao mais próximo delas, mas deixando de lado qualquer interpretação racional ou valorizada pelo próprio pesquisador, a fim de poder compreender o fenômeno que está pesquisando, de conformidade com o seu próprio modo de existir, e, num segundo momento, o "distanciamento reflexivo", em que o pesquisador procura se distanciar do que está investigando para refletir sobre a vivência que busca compreender e analisar, descrevendo depois os significados apreendidos nesse processo. 
Após o explicitado sobre a fenomenologia e, com o intuito de compreender a contribuição do acompanhante terapêutico, como tratamento em saúde mental, buscamos, no pensamento de Martin Heidegger, subsídios que nos auxiliem nessa jornada.

\section{1 - Heidegger: em busca de sentido para a existência humana}

Para Stein (1988), a obra de Heidegger impulsiona a filosofia do século XX, juntamente com Wittgenstein, com seu "Tractatus Lógico - Philosophicus" (1921), e com Lukacs, com a "História da Consciência de Classes" (1923).

Em sua obra, ele faz uma reflexão sobre a existência humana por meio do sentido do ser ${ }^{9}$. Parte de uma crítica à orientação metafísica do pensamento ocidental, questionando o próprio modo de ser e de habitar o mundo, enfim, de conduzir a própria vida, com intuito primordial de compreender o sentido da existência humana.

Heidegger propõe, em sua obra, uma análise existencial por meio de sua ontologia fundamental. Para Stein (1988), esse filósofo demarca um novo paradigma, que é o ser-nomundo prático, lançando uma alternativa para resolver o problema da ontologia ${ }^{10} \mathrm{e}$ da verdade.

Para ele, ser é o conceito mais universal, mas mesmo assim exige discussão e reflexão porque ainda é considerado o mais obscuro, exigindo, portanto, pensar sobre ele para buscar seu sentido, que é primordial à compreensão das coisas em nosso cotidiano.

O ser se mostra à existência humana imediata e concretamente. A ontologia apresentada por Heidegger propõe conhecer o ser a partir do seu sentido, ou seja, o ser

\footnotetext{
${ }^{9}$ Ser é "o conceito mais universal e mais vazio” (HEIDEGGER, 1988, p. 27). “(...) está naquilo que é e como é na realidade, no ser simplesmente dado, no teor e no recurso, no valor e na validade, na pre-sença, no há" (ibidem, p. 32). É a maneira como algo se manifesta, se torna presente e, é entendido, percebido e compreendido pelo ser-aí. É o que se torna manifesto.

${ }^{10}$ Ontologia - é a "parte da filosofia que trata do ser enquanto ser, isto é, do ser concebido como tendo uma natureza comum que é inerente a todos e a cada um dos seres" (ESPÓSITO, 1991, p. 86).
} 
inserido em seu mundo como co-agente, para superar o pensamento ocidental que buscava compreender o homem a partir das coisas de maneira objetiva, distanciada do objeto investigado, como se pudesse dicotomizar a existência.

Heidegger (1988), criando uma terminologia própria, busca compreender o sentido do ser. Ele denomina o modo de ser do homem como Dasein, que significa ser-aí ou estar-aí. É uma palavra alemã utilizada para denominar ser humano, pressupõe presença que engloba o indivíduo no conjunto, como existente humano. Evoca o processo de constituição ontológica de homem, ser humano e humanidade. Ontologicamente o homem se configura como passado, cotidiano, presente e possibilidades futuras e, portanto, como um ser temporal que em essência se mostra como projeto, possibilidade. Podemos ver em suas palavras:

(...) A pre-sença não é algo simplesmente dado que ainda possui de quebra a possibilidade de poder alguma coisa. Primariamente, ela é possibilidade de ser. Toda pre-sença é o que ela pode ser e o modo em que é a sua possibilidade (...) (HEIDEGGER, 1988, p. 198-99).

A presença, denominada de Dasein ou ser-aí, é a única que indaga, capaz de se questionar sobre o sentido do ser. Questionar é ir ao mais profundo do ser, para compreendêlo. Corresponde ao plano ontológico ${ }^{11}$, também chamado existencial, que pressupõe o indivíduo como ser-no-mundo, relacionando-se com as pessoas do seu universo social e também com as coisas denominadas de entes ${ }^{12}$.

De acordo com Heidegger, existe um outro plano, o plano ôntico ${ }^{13}$, também denominado existenciário, que compreende o que pode ser conhecido de imediato.

\footnotetext{
${ }^{11}$ São “...) as características fundamentais que possibilitam as várias maneiras de algo se tornar manifesto, realizado (...).” (SPANOUDIS, 1981, p. 11)

${ }^{6}$ Ente - são “(...) muitas coisas e em sentidos diversos (...) é tudo de que falamos, tudo que entendemos com que nos comportamos dessa ou daquela maneira, ente é também o que e como nós mesmos somos." (Heidegger, 1988, p. 32).

13 Ôntico - refere-se “(...) tudo o que é percebido, entendido, conhecido de imediato (...)”. (SPANOUDIS, 1981, p. 11).
} 
O humano é o único ser que interroga, questiona, porque tem como busca continuar a compreender a si mesmo; para tanto, ele busca, no contexto vivenciado, o significado, o sentido dessas vivências. Nada faz sentido isolado. Onde há ser, necessariamente há ente.

Nos dizeres de Critelli, há uma diferença entre ente e ser:

Esqueceu-se que ser não é uma substância, nem mesmo abstrata; que não é um objeto, uma coisa; que ser é simplesmente o modo daquilo que é. O ser não é uma forma substantiva mas verbal. Ser não é um substantivo, apenas o verbo ser na sua forma infinitiva. Ser é movimento; ser é sendo. Por ser modo de estar sendo do ente, por ser possibilidade em aberto, o ser não pode ser precisado, objetivado, aprisionado num único sentido (CRITELLI, 1981, p. 14).

Nessa perspectiva, encontramos uma explicação para que a filosofia heideggeriana seja conhecida como ontologia hermenêutica, já que busca, por meio da compreensão e interpretação da existência, do Dasein, como alcançar a questão do ser.

O indivíduo tem a capacidade de conhecer o ser. O ser não é uma coisa fechada, padrão. Somente é possível pensá-lo em contato com o mundo, portanto, em relação com o outro, seja ele um ente ou outro ser. A compreensão do ser ocorre a partir dele próprio, com as possibilidades mediadas pelos feitos que compõem o dia-a-dia desse ser.

O homem atual tem desenvolvido uma maneira de viver representando-se com seu pensar lógico-racional, analítico, buscando, antes de qualquer vivência, controlar-se. Mas é preciso ressaltar que, quando não significamos nossas vivências com o outro, essas vivências se transformam em coisas, sendo vividas como seres objetivados, em uma relação coisificada com o próprio homem, distanciando-o do mundo vivenciado.

Nesse sentido é que Heidegger busca compreender o homem, como ser finito que é, inserido no tempo e no espaço de sua existência e que possui, em seu ser, a capacidade de questionar e interrogar a si próprio. Nessa prerrogativa, ele tem a possibilidade de, sendo, estabelecer uma relação para compreender-se em sua essência. 
O homem, em sua condição ontológica, é fundamentalmente poder-ser, como um projeto, o que lhe outorga a responsabilidade e a obrigação de ser enquanto existente no mundo.

Existência, para Heidegger, é algo que emerge, que se manifesta, que se desvela.

Pasqua nos esclarece sobre os conceitos explicitados anteriormente:

A existência (Existenz), tal como Heidegger a entende, não tem o sentido medieval de existentia. Para ele, esta significa literalmente ser subsistente, aquilo que está perante a mão (...) Caracteriza os entes que estão fechados sobre si próprios, cristalizados como uma pedra: a existentia é algo de estático. A existência de que nos fala Heidegger é ek-stática. Caracteriza esse ente denominado Dasein, capaz de ser aquilo que projeta ser, de sair de si próprio, de ek-sistir (...) o Dasein é aquilo que ele pode ser. Ser, para ele, é poder ser este ente concreto, empenhado no mundo, cujo ser é permanentemente posto em jogo e como que arrancado de si próprio. A essência do Dasein não significa, portanto, o caráter estável e invariante daquilo que é, não é uma definição abstrata definitivamente válida (PASQUA, 1993, p. 36).

Para esse filósofo, o sentido de ser é muito mais profundo que pensar a existência

do homem. Em seus questionamentos, ele parte do sujeito inserido no mundo como um ser de presença ou, como ele diz, o ser-aí, que vive em relação com as coisas, com os outros e com o mundo. Essa interação ocorre em um constante vaivém entre o que é dado na situação e a realidade que se desvela na compreensão. Essa compreensão, segundo Heidegger, desenvolve-se antes da tomada de consciência reflexiva, do mesmo modo que a situação se manifesta antes da reação afetiva.

Para a filosofia heideggeriana, há duas maneiras fundamentais de o homem se relacionar com os entes ou com as coisas: de uma maneira sem nenhum envolvimento significativo que, assim, torna-se objetivado, denominado modo de ocupação, que pressupõe ter o que fazer com alguma coisa, produzir, realizar algo, impor-se, mas são modos deficientes de se colocar no mundo porque expressam um estar-com de maneira incompleta; e uma outra maneira, o relacionamento com o ente presente em um envolvimento significante, 
em que agimos mais do que teorizamos. Vivência que temos no cotidiano, também chamada de modo de preocupação.

(...) preocupação que não tanto substitui o outro, mas que se lhe antepõe em sua possibilidade existenciária de ser, não para lhe retirar o "cuidado" e sim para devolvê-lo como tal. Essa preocupação que, em sua essência, diz respeito à cura propriamente dita, ou seja, à existência do outro e não a uma coisa de que se ocupa, ajuda o outro a tornar-se, em sua cura, transparente a si mesmo e livre para ela (HEIDEGGER, 1988, p. 174).

Heidegger concebe o ser como ser de presença; ele é um ser-no-mundo descobrindo-se sempre como ser-com, como vemos em suas palavras: "Na presença está em jogo o seu poder-ser-no-mundo e, com isso, a ocupação que descobre na circunvisão o ente intramundano" (HEIDEGGER, 1988, p. 297).

“Ser-no-mundo é uma estrutura de realização" (HEIDEGGER, 1988, p. 20), em que o indivíduo existe inserido no mundo, com suas significações próprias, ou seja, um indivíduo contextualizado ou, como foi denominado por Heidegger, ser-aí ou ser de presença, que pressupõe o ser que designa o modo de ser objetivado "Ser está naquele que é e como é na realidade, no ser simplesmente dado" (idem, 1988, p. 32).

Essa presença nos impulsiona para o mundo, sendo ser-no-mundo, neste mundo em que o ser é lançado factualmente. O ser humano habita o mundo, é familiar e co-agente neste mundo, sendo um ser de possibilidade, já que é projeção e pode assumir diversas maneiras de apreender o mundo e relacionar-se com ele. De acordo com Spanoudis (1981), sendo-no-mundo (mundo entendido como além do mundo geográfico) significa as várias formas que o homem vive e pode viver, os modos como ele se relaciona com os entes.

A dinâmica de ser-no-mundo, compreendida no instante vivido, constitui o fenômeno da verdade, a partir de sua abertura para tal intento. Nessa perspectiva, para se mostrar é preciso ter abertura para a verdade, como podemos ver em suas palavras: "o homem é e está na verdade" (HEIDEGGER, 1988, p. 289). 
A abertura é o meio de onde o ser-aí se lança para a ação e para a descoberta. É nessa medida que o ser vai a busca da verdade, mas esta é temporal e manifesta-se na história que se desvela. Não há como uma verdade ser imutável e constante. Ela se revela na própria ação de quem a busca, sendo significada na compreensão do indivíduo.

O ser-aí ou Dasein tem como sentido estar-aí situado historicamente. Esse ser-nomundo vai se constituindo sendo-no-mundo antes de todo e qualquer eu, mas sempre situado e imerso no jogo sujeito/objeto, e é nessa interação que a realidade se dá. É sempre no contexto das coisas que obtemos os seus significados.

Para Heidegger (1988), o sentido só existe para o ser e pertence àquele momento; por isso ele considera o ser como ser de presença no mundo. Heidegger não concebe o homem apenas em relação a ele mesmo, mas sim, em contínua interação com todos os seres circundantes que interagem com ele. Dasein e mundo fazem parte de uma mesma realidade, por ele denominada ser-no-mundo.

Ser-no-mundo é condição fundamental do indivíduo. Ser humano é ainda sempre ser-com-o-outro, como podemos ver a seguir:

Os outros não são aqueles com quem o indivíduo convive, nem aqueles que o completam; os outros "constituem-no". Sem o outro, o indivíduo não é. A idéia corriqueira e metafísica da coexistência é de que esta é uma decorrência de indivíduos já existentes juntarem-se uns aos outros. Ela seria um "resultado". Primeiro, haveria a manifestação de indivíduos, depois sua relação (social), como decorrente de um encontro. No caso da fenomenologia, a coexistência não é um resultado, mas condição ontológica, uma condição que lhe é dado existir (CRITELLI, 1996, p. 78).

Heidegger (1988) concebe o ser como transcendente, porque este ser está em constante movimento de ir e vir entre o que é dado na situação e a realidade desvelada na compreensão, ou seja, ele está capacitado a atribuir um sentido ao ser, já que, para ele, o indivíduo não é um sujeito isolado, ele vive no mundo com o outro, sendo ser-com-o-outro; portanto, o ser-no-mundo é condição fundamental do homem em sua humanidade. 
Vale lembrar que emoções, valores e envolvimento não existem em si mesmos, como entidades, ou de maneira pronta e estática, mas, antes de tudo, são constituídos e compartilhados nas relações entre as pessoas.

O modo como o ser-aí se relaciona com os outros homens pode assumir várias formas de solicitude. Uma maneira de ser-no-mundo é o modo autêntico que emerge quando o indivíduo assume a responsabilidade primeira de cuidar de si, que se manifesta na aceitação da tarefa "ter que ser", que o impulsiona a cuidar do seu ser para assim se constituir enquanto ser humano, o que ocorre em um movimento permanente de "vaivém" do modo de ser do Dasein. Isso acontece nas vivências cotidianas que estimulam o indivíduo a refletir sobre a angústia, desilusão, agitação que acompanham a todos nós, seres humanos (MICHELAZZO, 1999).

Quando conseguimos cuidar de nós mesmos, podemos nos lançar a cuidar do outro e estar junto dele, favorecendo que ele assuma seus próprios caminhos, crescendo e encontrando-se consigo mesmo. Nessa perspectiva, ser-com-o-outro pressupõe um relacionamento significativo e envolvente, também chamado de autêntico cuidar.

É na medida em que o ser-com se revela como ser-si-mesmo, ser-autêntico, que é capaz de compreender o outro, pois a compreensão do outro ocorre por meio do cuidar solícito.

Uma outra maneira é ir ao encontro do outro trazendo para si o encargo de cuidar do outro, isto é, escolher por ele, fazer por ele, tomar seu lugar, dominá-lo para subjugá-lo, vivenciando assim uma maneira inautêntica.

Nas duas formas de solicitude, citadas nos parágrafos precedentes, existem nuances possíveis, no modo de ser-com cotidiano, que podem assumir formas deficientes e indiferentes de solicitude, como: ser-sem-o-outro; ser-contra-o-outro; passar-pelo-outro, demonstrando um não-se-importar-com-o-outro (HEIDEGGER, 1981). 
Na relação de submissão, há um afastamento: o ser se torna ser-lá, deixando de ser-si-mesmo, denunciando maneiras deficientes de solicitude, transformando o ser em impessoal ou em a-gente. Essa impessoalidade leva ao anonimato, ao afastamento, o que favorece a não-singularidade do ser, tornando-o ser-inautêntico.

Ao contrário, ser-autêntico pressupõe um ser-aí aberto às possibilidades da existência, inclusive a de não-ser ou de deixar de existir. O ser-aí é um ser-para-a-morte. A morte demarca a finitude do ser; ele voltará a ser o que era: nada (Heidegger, 1981). Essa experiência da morte é pessoal, intransferível e única. Não se pode morrer pelo outro e também não se morre mais de uma vez. E, ao assumir a sua finitude, o ser-aí atinge a autenticidade, pois se compreende como ser-para-a-morte.

Essa finitude articula seu sentido com a temporalidade. O tempo como finitude demarca o ser-para-a-morte, enquanto temporalidade, o sentido ontológico do cuidado. Podemos dizer que o homem, como ser-no-mundo, é essencialmente cuidado e só é percebido como cuidado na sua temporalidade, portanto nos modos-de-ser-no-mundo.

Frente à finitude da existência ou à possibilidade de não-ser, o ser-aí se angustia. A angústia é, pois, a ameaça de não-ser e, portanto, ela é inerente à existência. Atualmente, percebemos que o homem foge da angústia negando sua condição de ser-para-a-morte, fugindo de si mesmo, sendo ser-inautêntico.

No próximo item veremos a trajetória percorrida para o encontro com os colaboradores deste trabalho

\section{2 - O encontro com os colaboradores}

Participaram desta pesquisa seis colaboradores-clientes, portadores de sofrimento psíquico, que foram atendidos em AT e aceitaram participar deste estudo. Cinco 
colaboradores-clientes contaram com a participação de um familiar cada, exceto uma colaboradora que, seus familiares se recusaram a participar. Cinco agentes de saúde que visitaram as casas dos colaboradores. Todos os colaboradores estavam inseridos no Programa de Saúde da Família do Centro de Saúde Escola "Profa. Dra. Maria Herbenia Oliveira Duarte" que está ancorado ao Centro de Saúde Escola (CSE) da Faculdade de Medicina de Ribeirão Preto - Universidade de São Paulo (FMRP- USP).

\subsection{1 - Aspectos Éticos}

Este projeto foi submetido para avaliação ao Comitê de Ética da Escola de Enfermagem de Ribeirão Preto, antes dos dados desta pesquisa serem coletados, e foi aprovado conforme parecer de número 0393/2003 (anexo A).

Todos os colaboradores foram informados dos objetivos e procedimentos da pesquisa e sobre o Termo de Consentimento Livre e Esclarecido (anexos B, C e D), atestando sua vontade em participar da pesquisa.

\subsection{2 - Instrumento}

Utilizamos a entrevista semi-estruturada como instrumento de acesso à vivência dos informantes sobre a prática do Acompanhamento Terapêutico. Essa entrevista teve como questão norteadora para os agentes de saúde: "Fale-me como você percebe a atuação do acompanhante terapêutico no tratamento dos pacientes com sofrimento psíquico". No caso dos clientes, a questão foi "Fale-me como você percebe a atuação do acompanhante terapêutico no seu tratamento". E para os familiares foi apresentada a questão: "Fale-me 
como você percebe a atuação do acompanhante terapêutico no tratamento do seu familiar"

No início dos AT foi realizado o contrato de atendimento pela at e também foram explicitados os objetivos do trabalho da at e da pesquisa. Nessa ocasião, houve aceitação de todos os colaboradores, mesmo daqueles que posteriormente não participaram da entrevista. No término do AT, o colaborador-cliente foi convidado a participar da pesquisa, sendo entrevistado. As entrevistas foram gravadas e transcritas na íntegra.

\subsection{3 - Apresentando o espaço onde o Acompanhamento Terapêutico se inseriu}

O Centro de Saúde Escola "Profa. Dra. Maria Herbenia Oliveira Duarte", localizado na Vila Tibério, está ancorado ao Centro de Saúde Escola (CSE) da Faculdade de Medicina de Ribeirão Preto - Universidade de São Paulo (FMRP- USP) desde 1979, em convênio firmado, inicialmente, com a Secretaria da Saúde do Estado e, atualmente, com a Secretaria Municipal da Saúde de Ribeirão Preto (SMS-RP). Está alicerçado no tripé assistência, ensino e pesquisa.

Essa unidade de saúde localiza-se na área de abrangência do distrito central atendendo aos bairros de Vila Tibério, Vila Amélia, parte do Jardim Conceição, Vila Junqueira Uchoa e parte da Vila Lobato, com uma população de 16.610 habitantes.

Quando foi criado, o CSE - Vila Tibério era um Posto de Puericultura e posteriormente uma unidade de assistência materno-infantil, focalizando suas ações na assistência integral à saúde da criança e da mulher.

A partir de 2000, passou a dividir seu espaço com o Programa de Saúde da Família (PSF). Conta com uma equipe multiprofissional que atende a comunidade com médicos - um médico generalista do Programa de Saúde da Família, um ginecologista, dois 
pediatras, um clínico geral, duas enfermeiras, dois residentes em Medicina Geral e Comunitária, dois técnicos em enfermagem, cinco agentes comunitárias. E, ainda, tem o apoio de profissionais supervisores da USP, nas áreas de Clínica Médica, Saúde Mental e Psicologia da Saúde, estagiários de psicologia, enfermagem, medicina, além de profissionais voluntários: uma psicóloga que atende como at, três terapeutas ocupacionais.

O CSE da Vila Tibério, pela vinculação com a Universidade, tem sempre programas que favorecem um atendimento mais completo à comunidade e sempre empreende esforços para treinar sua equipe de profissionais, propiciando maior capacitação para resolver os problemas que surgem.

Este estudo teve início após o convite de uma das supervisoras, membro fundadora do GEAVIDAS ${ }^{14}$, para a pesquisadora-doutoranda do presente estudo para compor esse grupo de trabalho oferecendo o acompanhamento terapêutico nesse serviço. Com a necessidade de formalizar a participação da at no CSE, a pesquisadora procurou a Escola de Enfermagem com intuito de pensar a possibilidade dessa vinculação, o que foi feito com a construção de um projeto de pesquisa intitulado: “O Atendimento ao Indivíduo com Sofrimento Psíquico na Perspectiva de um Programa de Saúde da Família" que foi submetido à seleção no Programa de Pós-Graduação de Enfermagem Psiquiátrica da Escola de Enfermagem - USP-Ribeirão Preto.

A at trabalha diretamente com as agentes comunitárias, oferecendo Acompanhamento Terapêutico para as pessoas da comunidade que dele necessitem. Essa demanda é discutida na equipe ${ }^{15}$. Uma vez indicado para atendimento pela equipe, a agente

\footnotetext{
${ }^{14}$ GEAVIDAS é um grupo de trabalho, sem fins lucrativos, ancorado à FMRP-USP, que se propõe a estudar e atuar de maneira humanizada na assistência a vítimas de violência. Sua ação consiste, além do atendimento às vítimas, atuar em supervisões e também desenvolver recursos para informação e capacitação dos profissionais que, direta ou indiretamente, atendem essas pessoas. Esse trabalho é realizado através de reuniões, supervisões, treinamentos e sensibilizações para intervenções eficazes.

${ }^{15}$ Equipe que trabalha diretamente com ações de combate a violência entra e extra familiar. É composta por uma médica pediatra (gerente da Unidade), uma médica psiquiatra (supervisora de Saúde Mental e violência
} 
comunitária oferece o atendimento de AT para o cliente e os apresenta. A at avalia as necessidades do atendimento e, juntamente com a equipe, traça o projeto terapêutico ${ }^{16}$, bem como as condutas e os encaminhamentos pertinentes.

Como prática que se inclui no social e atua no ambiente do cliente, o at atendeu, inicialmente, na casa do cliente e, posteriormente, em diversos locais onde se fizeram necessários, de acordo com o projeto terapêutico e as possibilidades do momento de atendimento.

doméstica da FMRP- USP e GEAVIDAS), um psicólogo social, estagiários de psicologia e medicina, uma assistente social do GEAVIDAS

${ }^{16}$ Esse projeto traça as diretrizes e foco do atendimento. 
5 - CONHECENDO OS COLABORADORES 
Neste momento do trabalho, apresentaremos ao leitor que nos acompanha os colaboradores deste estudo, a síntese do AT, realizado com cada um deles, e fragmentos das entrevistas realizadas com a pessoa em sofrimento psíquico, seus familiares e as agentes comunitárias, com intuito de mostrar o fenômeno que buscamos compreender .

\section{1 - A pessoa em sofrimento psíquico ${ }^{17}$}

\subsection{1 - A título de uma apresentação}

Ari, 70 anos, pai de família. Morava, sozinho, em uma casa cedida pela irmã mais velha. Foi encaminhando para o trabalho de Acompanhamento Terapêutico pela equipe do PSF, pela dificuldade de remissão dos sintomas depressivos, cuidado de si mesmo prejudicado, dificuldade de aderência ao tratamento oferecido pelo Serviço de Saúde Mental especializado, dificuldades para seguir a orientação medicamentosa prescrita, e pelo quadro dermatológico prejudicado.

Vânia, 54 anos, morava com os pais idosos. Após o AT contava com a assistência de uma empregada, Marcolina, durante o dia. Era responsável pelos cuidados com a medicação dos pais e cuidados com a higiene da mãe e pequenos trabalhos domésticos, supervisionados por Marcolina. O AT foi solicitado devido à gravidade e emergência do caso - uma pessoa em sofrimento psíquico, sem tratamento psiquiátrico, e a recusa dela em aceitar qualquer tratamento de saúde.

Elaine, 45 anos, morava sozinha em casa própria. Tinha o apoio da mãe e percebemos relacionamento distante com outros familiares. O AT teve como principal objetivo trabalhar adesão ao tratamento psiquiátrico e melhor organização de sua casa.

\footnotetext{
${ }^{17}$ Os nomes dos colaboradores e de todas as pessoas citadas por eles foram trocados com intuio de preservar suas identidades.
} 
Edivânia, 22 anos, casada, morava em casa alugada com o marido e uma irmã. Veio para AT, quando estava grávida de sete meses, devido à ansiedade e comportamentos de risco como sair de casa para caminhar, de madrugada, sem avisar ninguém colocando sua vida e a do bebê em risco.

Sandra, 45 anos, morava com a mãe, em casa alugada. A solicitação pelo AT ocorreu devido aos comportamentos verbais agressivos e provocativos, brigas freqüentes com a mãe e vizinhos e sexualidade exacerbada.

Daniela, 40 anos, casada. Morava com o marido em casa cedida pela família dela. Apresentava dificuldade de relacionamento com a irmã e com a mãe. A demanda pelo AT foi devido a comportamentos de risco da paciente como não seguir o tratamento psiquiátrico prescrito de maneira correta, compras excessivas sem ter condições de saldar suas dívidas.

\subsubsection{1 - Apresentando Ari}

Ari, 70 anos, aposentado por invalidez, morava sozinho. Trabalhou, a partir da vida adulta, com raspagem de sinteco. Durante a adolescência gostava de 'aproveitar a vida' sair, beber, usar droga (informação que somente o familiar nos forneceu.

Referiu ter aproveitado muito a vida, viajado e morado em São Paulo por um período breve. Quando voltou para Ribeirão Preto, aos 25 anos, passou a morar com a primeira mulher (Pedrina, que era casada, na época). Viveram durante 40 anos juntos e ficou viúvo (ela morreu de câncer de pulmão). Dessa união, teve uma filha legítima e uma filha adotiva. Relatou bom relacionamento com Pedrina e afirmou, várias vezes ao longo dos atendimentos, a capacidade de trabalhar. 
Depois de ter ficado viúvo continuou morando com as filhas, cuidando delas e trabalhando. Referiu que, nesta época, cuidava da casa, trabalhava na sua empresa, preparava a alimentação delas e freqüentava o bar, para tomar cerveja.

Após sete meses, conheceu sua segunda mulher (Nilza), com quem teve um filho; conviveram por dois anos, mas havia muitas brigas entre o casal. Ari explicou que Nilza era muito ciumenta, principalmente com relação às filhas e à lembrança de Pedrina, o que causava confusão e muitas discussões. Relatou dificuldades com as filhas porque elas não aceitaram o relacionamento, principalmente a mais velha. Devido as brigas, o casal separou-se e Nilza mudou para outra cidade do interior paulista, onde sua família residia. Ari mandou a pensão até seu filho completar 11 anos e parou de fazer os depósitos após orientação de um advogado. Ari alegou falta de condições financeiras para saldar esse compromisso.

Após a separação da segunda mulher, o paciente sentiu-se triste. De 1994 até 2001 passou por três internações psiquiátricas em hospitais diferentes da cidade. Quando teve alta foi encaminhado para o ambulatório de referência, mas abandonou o tratamento. Em 2001, procurou o Posto de Saúde, sendo encaminhado para o Programa de Saúde da Família.

Ao PSF chegou impregnado por Haloperidol, apresentando ansiedade, tristeza, dificuldades para realizar suas atividades cotidianas, como higienização pessoal, organização da casa e alimentação, alegou ainda, insônia, ideação suicida, idéias persecutórias, angústia, medo e uma coceira pelo corpo, sem diagnóstico; estes sintomas denunciavam uma depressão. Seu diagnóstico foi de depressão grave, hipótese diagnóstica do Código Internacional de doenças (CID-10) de transtorno depressivo recorrente, episódio atual grave, com sintomas psicóticos (F 33.3). Posteriormente, no Serviço de Saúde Mental seu diagnóstico evolui para transtorno depressivo recorrente, atualmente em remissão (F 33.4). 


\subsubsection{1 - Síntese do Acompanhamento Terapêutico de Ari}

$\mathrm{O}$ atendimento do at foi aceito prontamente pelo colaborador. No início, foi realizado um contrato de atendimento em que foi esclarecido sobre o AT, sendo traçados, com ele, os objetivos do atendimento. Este procedimento também foi realizado depois da avaliação, pelo at, das necessidades de Ari.

Durante os atendimentos, Ari sempre foi muito solícito e disposto a mudar, o que favoreceu o fortalecimento egóico dele. $\mathrm{O}$ at trabalhou o fortalecimento de sua capacidade interna de gerir sua vida, reorganização de seus projetos de vida dentro de suas condições físicas, sociais e econômicas, organização da limpeza de sua casa, suas roupas, alimentação e de sua higiene pessoal. Tínhamos, ainda, como objetivos, a adesão ${ }^{18}$ de Ari ao Serviço de Saúde Mental e o seguimento das prescrições medicamentosas do tratamento. No início dos atendimentos, Ari vivia isolado, saindo de casa para ir ao PSF, a alguns consultórios médicos e ao banco ou ao comércio próximos a sua casa, mas sem regularidade, muitas vezes perdendo consultas.

O trabalho foi realizado por aproximadamente um ano, sendo suspenso quando Ari aderiu ao Serviço de Saúde Mental, seguindo a prescrição medicamentosa, e demonstrou capacidade de gerir sua vida adequadamente, inclusive cuidando de maneira satisfatória de suas necessidades básicas, como alimentação, higiene, contato social, cuidados com a saúde e preocupação com sua qualidade de vida.

\footnotetext{
${ }^{18}$ Adesão consiste em aceitação e participação no tratamento e no Serviço de Atendimento, no caso CAPS.
} 


\subsubsection{2 - Apresentando Vânia ${ }^{19}$}

Vânia, 54 anos, foi acompanhada por quatro meses pela at. Morava em uma casa da família, com seus pais e um cachorro, em um bairro de classe média que divide pontos comerciais e residenciais. A casa era antiga, com piso de assoalho e possuía quatro quartos, uma sala, varanda, quintal amplo com várias árvores frutíferas.

Os pais idosos não tinham condições de se responsabilizar pelo tratamento e medicação da filha. Vanildo, irmão da colaboradora, ficava uma parte do dia na casa para preparar a alimentação deles, acreditava que Vânia tinha condições de cuidar sozinha de si.

Uvanildo, outro irmão da colaboradora, morava em outra cidade e, segundo a família, era freqüente na casa. O relacionamento dele com Vânia era prejudicado devido à intervenção dele, juntamente com a polícia, na sua última internação psiquiátrica; ela afirmava constantemente que não queria qualquer aproximação dele, repetindo a história da última internação que foi realizada à força.

Valquíria, irmã que morava em outra cidade distante $300 \mathrm{~km}$ da cidade de Vânia, era casada, tinha boas relações com Vânia. Essa colaboradora referia-se a ela como uma pessoa boa, mas denunciava um vínculo distante.

Vânia estava sem acompanhamento e medicação psiquiátrica desde 2002 e tinha um diagnóstico, pelo CID-10, compatível com esquizofrenia, apresentava comportamentos bizarros, como defecação no chão, presença de delírios e alucinações de cunho religioso e já estava com dificuldades de estabelecer diálogos coerentes com sua família.

Nossa colaboradora tinha quebrado o braço direito, meses antes do início do AT, em um tombo e essa fratura se consolidou sem ter sido cuidada, devido à recusa dela em aceitar atendimento, gerando dores constantes no braço e redução de movimentação normal

${ }^{19}$ Os nomes aqui foram trocados usando uma semelhança real com intuito de mostrar a confusão causada por tal fato. 
com ele, o que dificultou e impediu a realização de atividades como pentear os cabelos, vestirse, deitar e levantar-se da cama.

\subsubsection{1 - Síntese do Acompanhamento Terapêutico de Vânia}

Foi solicitado o AT devido à recusa dela em seguir o tratamento psiquiátrico acompanhamento médico e medicação, uso de medicação prescrita de maneira adequada, cuidado de si. Na época não dormia na cama por causa do braço que havia quebrado. Não aceitava ser tratada de complicações orgânicas como anemia, sangramento vaginal ininterrupto e erisipela bulhosa.

Após a avaliação das necessidades de Vânia, conversas com a família, com o PSF, busca de informações sobre o acompanhamento dela no NAPS (ela tinha sido entrevistada, mas nunca aceitado atendimento naquele serviço), foi realizado o projeto terapêutico conjuntamente com o médico da família e a agente comunitária. Posteriormente foi discutido com Vânia e refeito o contrato de atendimento. Ela foi atendida em dois encontros semanais, por um período de quatro meses.

Inicialmente, Vânia não demonstrou interesse e abertura, vinculando-se posteriormente à at. Os atendimentos aconteceram em sua casa, muitas vezes sua mãe juntouse a nós, mas suas participações eram pautadas em conteúdos organizados coerentemente misturados a outros incoerentes, já apresentando as dificuldades próprias do mal de Alzheimer, o que incomodava sua filha. O pai, frequientemente, ficava sentado na varanda lendo a Bíblia.

As intervenções da at nesse trabalho foram no sentido de conscientizá-la da necessidade dos tratamentos que precisava fazer para cuidar de sua saúde, não só mental como também física. 
Com o intuito de ampliar seus movimentos e recursos sadios como cuidar de sua higiene pessoal, roupas e organização, foram propostas caminhadas, junto com o at, próximas à sua casa que, apesar de sua recusa, favoreceram suas saídas sozinhas, para dar volta pelo quarteirão de sua casa.

Durante os atendimentos em AT, a equipe do PSF e a at tentaram várias estratégias para conscientizar Vânia e sua família (pais e Vanildo) de suas necessidades por tratamento devido à gravidade de seu estado de saúde. Para Vânia não havia problema nenhum e ela acreditava que se tivesse qualquer problema Deus cuidaria dela, como vinha fazendo. Evidenciava não perceber nenhuma anormalidade com ela que necessitasse de acompanhamento médico. Com o agravamento do seu quadro orgânico, foi contatado seu irmão Uvanildo (contra a vontade da paciente) para colocá-lo a par da necessidade e emergência de cuidados que sua irmã requeria.

Esse procedimento favoreceu que Vanildo e Uvanildo buscassem ajuda do PSF para a internação de Vânia. Nesse sentido, a at trabalhou com Vânia para que ela aceitasse a internação já que traria melhor qualidade de vida para ela porque percebia que sua perna estava incomodando-a com os edemas. Sua fala oscilou em consentir com a internação e recusar, demonstrando grande confusão mental.

A internação aconteceu, inicialmente, em hospital geral, para tratar das intercorrências orgânicas e, posteriormente, internação psiquiátrica. Após a alta hospitalar, ela se vinculou ao CAPS e aceitou tratamento psiquiátrico e medicação, mas recusou qualquer outra atividade naquele serviço (grupos terapêuticos). Suas interações em casa ficaram mais coerentes e lúcidas, participando das atividades da casa como arrumar a cozinha e guardar as louças, se responsabilizou pela medicação e cuidados com a mãe que requeria muita atenção dela com solicitações constantes. 
A família se reorganizou contratando uma profissional para cuidar da casa, da alimentação e dos pais, e uma pessoa para acompanhar os pais e Vânia aos médicos. A vinculação de Vânia dentro da casa melhorou.

Quanto ao AT, Vânia não aceitou mais o atendimento, responsabilizando a at pela internação psiquiátrica. Sua família se ausentou de assumir a responsabilidade pelo atendimento, recusando-se em receber a at por inúmeras vezes.

Durante a entrevista desta pesquisa, foi percebido que a colaboradora teve compreensão da importância que a internação fez para sua vida e sua saúde, demonstrando um misto de reconhecimento da necessidade e ressentimento por ter sido feito.

\subsubsection{3 - Apresentando Elaine}

Elaine, 45 anos, separada, tem dois filhos que moravam com o pai, ela os via apenas na porta da escola, estava em separação litigiosa do marido. Segundo os relatos da colaboradora, a separação ocorreu depois que ela viu seu marido abusando sexualmente dos filhos. Ela também relatou que, depois desse episódio, eles conviveram por alguns meses e ela não confiava mais nele. Houve muitas brigas nesse período com ofensas pessoais, até com agressão física dela para com ele. Na última briga, ocorrida antes da separação, eles tinham se agredido fisicamente e a família dela interveio; houve a presença da polícia também.

Com Elaine moravam seis gatos que foram procriando e ficando na casa. Ela relatou tratar de maneira adequada, mas dizia precisar doá-los devido ao excesso de gasto com ração e considerava a hipótese de castrar os que ficassem com ela.

A casa em que morava é da família, composta de dois quartos, cozinha, quintal, situada em um bairro residencial de classe média. Recebia uma pensão alimentícia do marido 
e uma cesta básica de um programa assistencial religioso. Costumava almoçar na casa dos pais, e o jantar e café da manhã eram feitos em sua casa.

Elaine cursou o segundo grau e terminou, um pouco antes da separação do marido, um curso técnico de protética, atividade que não chegou a exercer, segundo os técnicos que a atenderam. De acordo com os relatos dela e da mãe, ela tinha montado um laboratório de prótese.

O relacionamento de Elaine com a mãe pareceu distante, com oscilações de afeto de neutro a positivo e, da mãe com Elaine, parecendo haver desaprovação e afastamento, oscilando para assistência durante as internações de Elaine. Durante os atendimentos, a at, solicitou ajuda da mãe e, enquanto a ajuda consistiu em intermediar as ligações entre Elaine e a at, ela (a mãe) foi solícita. Quando essa ajuda exigiu a abertura de sua casa para receber Elaine e at, foram negados apoio e participação.

\subsubsection{1 - Síntese do Acompanhamento Terapêutico de Elaine}

O pedido de AT foi solicitado devido à baixa adesão ao PSF e ao NAPS (atual CAPS), às histórias recorrentes de abandono de tratamento e às internações psiquiátricas e reinternações psiquiátricas e ao risco que oferecia a si mesma, já que morava sozinha e tinha sido denunciada por um acidente do namorado que morreu queimado em sua casa.

O AT com Elaine ocorreu, inicialmente, em sua casa. A at chegava, entrava na residência, conversavam e saíam pelas ruas próximas com o propósito de fazer exercícios físicos, já que Elaine tinha uma vida sedentária e suas atividades consistiam em ir à casa dos pais almoçar, freqüentar o CAPS duas vezes por semana, o que não ocorria com assiduidade. A casa era muito escura e com aspecto envelhecido. 
Após colher dados sobre Elaine nos serviços que a atendiam, a at ficou sabendo do fato que a colaboradora acusou uma funcionária pública, que havia ido fazer uma visita domiciliar em sua casa, de roubo e a história da morte do namorado queimado em sua casa depois de uma discussão sem que nada tivesse sido comprovado. Estes relatos, aliados ao o medo da at em permanecer sozinha com ela em sua casa, provocaram alterações no trabalho do AT com essa paciente. A at propôs que as visitas fossem feitas no alpendre da casa de Elaine, e as saídas continuaram pelo bairro.

Foram propostas outras saídas, havendo intervenção da mãe falando que eram arriscadas e muito complicadas para Elaine. Após um convite para visitar um parque onde Elaine poderia, além de fazer os exercícios físicos, passear, pôde ser percebida a dificuldade dessa cliente para se organizar para ir, e a intervenção da mãe alegando a distância como complicador e justificador para que a colaboradora não fizesse tal atividade.

Ao longo do AT, a colaboradora planejou fazer várias coisas que iam desde continuar a exercer sua profissão de protética até fazer curso de manicure e exercer tal função. Essas idéias se perdiam ao longo do tempo, à medida que apareciam outras, consideradas por ela como mais interessantes. Efetivamente foi possível perceber uma dificuldade em realizar seus projetos, principalmente porque eles sempre tinham uma grandiosidade desproporcional à condição real da colaboradora.

Ao longo dos atendimentos, Elaine apresentou uma idéia delirante de que a at poderia denunciá-la por roubo, já que deixava sua bolsa em sua casa, durante as caminhadas. Isso ocorreu no atendimento seguinte a um comentário da at, ao deixar sua bolsa em sua casa e perguntar a ela se o gato poderia derrubá-la. Após esse incidente, os AT foram interrompidos e a at entrou em contato com a mãe propondo que o encontro com a acompanhante terapêutica fosse realizado na casa dela, o que foi negado prontamente pela mãe com a alegação desta de que iria atrapalhá-la. 
Foi discutido na equipe do PSF e decidido que a at faria o atendimento em consultório com a proposta de AT, ou seja, atendimento no consultório e saídas para o espaço social, dependendo da necessidade e interesse de Elaine. Os encontros passaram a acontecer no consultório, período em que ficávamos conversando e refletindo sobre o material que Elaine trazia; as saídas não mais ocorreram. Esse atendimento durou mais três meses, quando a paciente pediu para antecipar as férias de final de ano (era dezembro). Foi combinado que ela retornaria em janeiro.

Em janeiro a at ligou para a mãe informando sobre o retorno ao atendimento e solicitando que ela intermediasse o contato para agendar o atendimento. A mãe informou a at que Elaine estava de repouso, por solicitação do médico, devido a sangramentos vaginais e que assim que ficasse boa marcaria um horário. Um mês depois foi realizado outro contato telefônico com a mãe, e ela informou que sua filha estava boa, continuava em tratamento no CAPS, mas não continuaria o AT, apesar de gostar do tratamento, por estar fazendo um curso preparatório gratuito para vestibular. Foi tentado contato telefônico com Elaine, porém, sem sucesso, pelo fato de seu telefone estar desligado.

Elaine, após o início do AT não foi internada em hospital psiquiátrico e percebemos melhor adesão às consultas e tratamento psiquiátrico e uma vinculação familiar mais satisfatória. Não havendo mais reclamação dos vizinhos quanto a seu comportamento inapropriado com relação aos gatos e aos cuidados consigo mesma.

\subsubsection{4 - Apresentando Edivânia}

Edivânia, 22 anos, casada. Iniciou o acompanhamento terapêutico quando estava grávida de sete meses, do seu primeiro filho. Morava com o marido Vinícius e a irmã Patrícia em uma casa de quatro cômodos. 
Natural do Piauí, veio morar em Ribeirão Preto para trabalhar porque lá não tinha emprego e os que havia pagavam pouco. Ela tinha uma vida difícil junto com sua família. Empregou-se em uma casa em Ribeirão Preto, como empregada doméstica. Veio para essa cidade com a irmã.

Conheceu o marido na escola, quando cursaram o colegial. Namoraram e resolveram morar juntos. Após um ano de relacionamento conjugal, resolveram se casar no civil. Como acharam que os pais dele iriam ser contra a união, somente informaram sobre o casamento no dia. A paciente pressionou o marido para terem uma casa só deles para morarem. A família dele ajudou a comprar os móveis e alugaram uma casa. Resolveram ter um bebê e Edivânia engravidou.

Edivânia passou muito mal no início da gravidez e parou de trabalhar. Começou a apresentar muita ansiedade e necessidade de conversar que nem sempre era expressa para os familiares. O marido demonstrava ter paciência com a esposa, mas como trabalhava durante o dia, à noite tinha sono, ao contrário da colaboradora que queria conversar.

Edivânia relatou nervoso freqüente, ansiedade excessiva e angústia, mas quando foi oferecido atendimento no CAPS, para acompanhamento com médico psiquiatra, ela demonstrou grande dificuldade de organização para aceitar essa proposta de tratamento. Depois de vários atendimentos e esclarecimento sobre o atendimento psiquiátrico, o serviço oferecido pelo CAPS e sua necessidade de tratamento, ela se comprometeu em ir, fato que nunca ocorreu por diversos motivos, desde falta de companhia para ir, já que seu marido já estava trabalhando, dificuldade em levantar cedo e, ainda, vontade e capacidade para cuidar da sua saúde mental sem atendimento no serviço especializado. 


\subsubsection{1 - Síntese do Acompanhamento Terapêutico de Edivânia}

O AT foi requerido pelo médico do PSF, juntamente com a agente comunitária devido aos comportamentos da paciente que estava grávida e muito ansiosa. Tinha comportamentos desorganizados como sair de madrugada pelas ruas de seu bairro, algumas vezes de camisola sem avisar seus familiares. Durante o dia, ligava para o marido, em seu emprego, o que colaborou para ele ser mandado embora, ficando desempregado e precisando da ajuda dos familiares dele para se manterem. Uma outra queixa era a compra excessiva, por Edivânia, de bens de consumo como eletrodomésticos, contraindo dívidas no mercado local, comportamento exarcebado após a gravidez.

Edivânia foi atendida em AT de agosto a dezembro de 2005 com interrupção de vinte dias, quando o bebê nasceu, em dezembro do mesmo ano. Inicialmente foram dois atendimentos semanais e depois do nascimento de João Vítor os atendimentos passaram a ser semanais.

Durante os atendimentos, as sessões transcorreram naturalmente com conversas com a colaboradora, freqüentemente seu marido participava juntamente com ela do atendimento, quando então foram feitas orientações quanto à ansiedade que a paciente relatava, suas dificuldades e as dificuldades que o casal enfrentava. No início do AT, nossa colaboradora estava sempre dormindo quando a at chegava. Ao longo dos atendimentos foi percebida que essa colaboradora manteve uma rotina de horários mais adequada com conseqüente espera pelo atendimento da at por parte dela.

Edivânia sempre demonstrou interesse pelas visitas, sua fala era coerente, com conteúdo lógico. Uma das orientações da at foi a avaliação psiquiátrica que seria realizada no CAPS devido à grande ansiedade que apresentava e o risco para si e para o bebê, o que não ocorreu devido à dificuldade de Edivânia em encontrar tempo para ir, já que a triagem era 
feita duas vezes por semana, a três pacientes, que seriam atendidos por ordem de chegada ao serviço.

O AT terminou quando nossa colaboradora passou a demonstrar comportamentos mais adaptados à sua vida, não apresentava mais ansiedade exagerada que a impelia a comportamentos disruptivos e demonstrava melhor equilíbrio para lidar com seu cotidiano, como esperar o marido voltar do trabalho sem ligar para ele no trabalho, cuidar do filho, não sair à rua sozinha ou em condições que colocasse sua vida em risco e afirmou não querer mais as visitas da at em sua casa, por acreditar não precisar mais de AT.

\subsubsection{5 - Apresentando Sandra}

Sandra tem 45 anos, portadora de necessidades especiais com diagnóstico de síndrome de Down. Mora com a mãe Da. Margarida, 72 anos e aposentada.

A condição socioeconômica da família permitiu visualizar que residiam em uma casa alugada, em um bairro que divide residências e alguns pontos comerciais. A casa possuía quatro cômodos assim distribuídos: dois quartos, uma sala, uma cozinha, um quintal onde havia o tanque, um espaço com plantas que era usado para secar roupas. A renda da família provinha da aposentadoria da mãe e da pensão de Sandra deixada pelo pai falecido. Da. Margarida tem uma casa própria em um conjunto habitacional onde vivem dois irmãos de Sandra com suas respectivas famílias, mas não pagam aluguel. Da. Margarida teve seis filhos sendo que uma é adotiva, nenhum contribuía com a renda familiar delas.

Da. Margarida sempre trabalhou com limpeza de bancos para uma empresa terceirizada. Devido ao desentendimento da filha, Sandra, com dois meninos - Hugo e Tiago —, que eram seus vizinhos e moravam em frente à sua casa, parou de trabalhar. O desentendimento ocorreu depois que os laços entre Sandra e os dois meninos foram 
estreitados e houve um rompimento de relações por causa do interesse de Sandra em namorar um dos garotos. Ela, além de chamá-lo para namorar, passou a mão em suas pernas, e usava termos como transar, beijar na boca, etc., o que a mãe deles não aceitou e proibiu a entrada de Sandra na casa. Sandra não se conformou com tal fato e sempre que os via, xingava-os e ficava provocando com música alta e danças provocativas do outro lado da calçada, às vezes até de sua casa mesmo.

Com o agravamento da indisposição entre Sandra e a família vizinha, Da. Margarida parou de trabalhar para cuidar da filha, fato que várias vezes veio à tona com tom de queixa por parte dessa senhora.

Em decorrência da presença da mãe na casa por maior tempo e falta de um planejamento e comunicação entre ambas, Sandra, que se responsabilizava por esquentar sua alimentação, pela limpeza e organização da casa deixou de fazer essas tarefas, ficando a seu cargo arrumar a cozinha do almoço e do jantar e passou a esperar pela mãe para as outras atividades.

O relacionamento de Sandra com a mãe foi marcado por brigas e desentendimentos, principalmente quando ela se opunha à vontade de Da. Margarida. Percebeu-se agressividade de ambos os lados.

\subsubsection{1 - Síntese do Acompanhamento Terapêutico de Sandra}

O at foi solicitado pela agente comunitária devido à mudança de comportamento de Sandra: antes dócil e flexível às ordens da mãe, agora marcado pela agressividade verbal de Sandra para com Da. Margarida, briga com os vizinhos, fato que deixou a relação insustentável já que Sandra sempre que os via punha música alto e começava a fazer gestos provocativos ou danças sensuais, dobrando e puxando sua bermuda para cima (segundo relato 
da mãe e da Agente Comunitária Gabriela que atendia aquela residência), Enfim, um relacionamento com a mãe pautado por brigas e desentendimentos e, ainda, sexualização exacerbada com gestos obscenos e falas provocativas.

No início, foi realizado um contrato de atendimento com Sandra e com sua mãe, em que foi esclarecido sobre o acompanhamento terapêutico, sendo traçados, com elas, em momentos diferentes, os objetivos do atendimento.

O AT foi aceito prontamente por Sandra que verbalizou alegria em ter com que conversar e por Da. Margarida, sua mãe. Por diversas vezes, Da. Margarida relatava falta de alimentos e remédios para Sandra ou a dificuldade para adquiri-los. A mãe relata que estava indo auxiliar Cinira, uma das filhas, mas que ela não lhe pagava nada por essa ajuda.

Quando iniciado o AT, Sandra já freqüentava o grupo de artesanato: “Arte e companhia" e de saúde: "Descontração e Saúde". Não realizava nenhum trabalho no grupo de artesanato. Sua participação era marcada por solicitações constantes à coordenadora, principalmente à Gabriela, agente comunitária que atendia a sua residência. Seu comportamento era pautado por ciúmes de qualquer pessoa que chegasse perto de Gabriela. Hugo e Tiago faziam outra atividade próximos à sala onde ocorria o grupo de artesanato. A presença deles tirava a atenção dela e, muitas vezes, a deixava inquieta. Ela sabia fazer crochê e sempre estava tecendo um trabalho que, a certa altura, era desmanchado e reiniciado. Ela acreditava que não poderia fazer o trabalho até que ele crescesse e virasse uma toalha de mesa.

Ao longo dos atendimentos, Da. Margarida, usualmente, teceu várias críticas a Sandra, sempre enfatizando os comportamentos negativos da filha como xingar nomes feios, a recusa em ir para casa da filha Vilma ou Zilda. 
As críticas de Da. Margarida denunciavam a angústia e a frustração dela com a percepção da mudança de Sandra em aceitar suas ordens e orientações, inclusive de lidar com o envelhecimento de Sandra.

$\mathrm{O}$ atendimento com a at foi marcado por várias reclamações da mãe aos comportamentos da filha sem, contudo, acreditar que algo pudesse ser feito. As reclamações eram infindáveis, tendo sido preciso, inúmeras vezes, pedir para que Da. Margarida parasse para que Sandra pudesse ser ouvida. Nesses momentos, a at buscou promover a comunicação entre elas para que houvesse uma compreensão entre ambas, ocasião em que Sandra sempre dizia que iria melhorar e se propunha a mudar suas atitudes. A mãe nunca verbalizou vontade de ceder em prol de um relacionamento mais harmonioso entre ambas.

Da. Margarida trazia queixas recorrentes de malcriações da filha. Em conversa com as duas, percebi que essas grosserias ocorreram, na maioria das vezes, quando Da. Margarida tentava impor sua vontade a Sandra, como, por exemplo, quando queria que a filha passasse o final de semana na casa da filha Vilma para ela ir ao baile sem a preocupação de deixá-la sozinha em casa, ou então, para ela se encontrar com o namorado que é um homem casado.

Houveram ocasiões em que, conversando com as duas, Sandra verbalizou interesse em ir passar o final de semana na casa da sua irmã Cinira e a mãe se opôs, dizendo que ela poderia escolher entre Vilma e a outra irmã Zilda, mas com Cinira não, alegando que ela não ficava em casa e que Sandra ficaria sozinha com os dois sobrinhos (filhos de Cinira), com quem Sandra gostava de ficar. Um dos motivos de Sandra não querer ficar na casa de Zilda era a afirmação dela de que a irmã a obrigava a fazer trabalhos domésticos, fato que a mãe desmentiu.

Foi proposta caminhada para Sandra, atividade que, inicialmente, foi realizada junto com a at. Como nossa colaboradora sabia andar pelas ruas do bairro, conhecia muitas 
pessoas e demonstrou domínio da atividade, foi proposto que ela realizasse esse exercício sozinha, fato que não aconteceu, o que me levou a propor exercício físico em grupo, realizado duas vezes por semana no Núcleo de Saúde com a orientação de um profissional da Educação Física, participação que Sandra manteve desde então.

Nos grupos de que fez parte - de artesanato e saúde - a qualidade de participação melhorou e ampliou o leque de possibilidades de atividades: ela já teceu toalhas de crochê em formato redondo e com os círculos pequenos, e uma participante do grupo uniu-os e fez uma almofada que Sandra dispôs no sofá de sua sala. Nos passeios realizados pelo "grupo de saúde", ela demonstrou participação mais colaborativa e menos dependência das coordenadoras.

Foi bastante presente, durante os atendimentos, a falta de estimulação da mãe, mesmo com orientação da at. Quando Sandra tinha comportamentos adequados ou próximos dos desejados por ela, Da. Margarida os negava, dizendo que quando a at saísse tudo voltaria como antes.

O AT está em andamento desde novembro de 2004, e agora ocorre quinzenalmente como planejamento para término do atendimento.

\subsubsection{6 - Apresentando Daniela}

Daniela tem 40 anos, casada com Josué. Morava em uma casa cedida pela família dela, dividida ao meio, com o irmão. A irmã aposentada e a mãe moram em Campinas.

Segundo seu discurso, sofria de transtorno esquizoafetivo e transtorno borderlaine desde 1992. É historiadora, professora da Rede Estadual de Ensino. No início do AT estava afastada de suas atividades como professora (desde março de 2003). Com ajuda dos laudos 
psiquiátricos, conseguiu ser readaptada, retornando ao trabalho em setembro de 2003, realizando atividades na biblioteca da escola onde esteve lotada.

Daniela refere ter tido dificuldades de relacionamento com a mãe que era severa, distante e pouco afetuosa. Relatou bom relacionamento com o pai falecido, relacionamento com os irmãos de maneira distante. Referiu adolescência como uma pessoa quieta, com poucos amigos. Durante o período em que cursou faculdade de história também não tinha muitos amigos. Matriculou-se à noite e trabalhava durante o dia.

Conheceu Josué no NAPS, onde ambos faziam tratamento, resolveram se casar. A família dele era bastante solícita e participativa na vida deles. A mãe dele ajudava-o, incentivando com seu trabalho, que consistia em vender salgados nas empresas, de bicicleta, atividade que fazia todas as manhãs até quando saiu a readaptação de Daniela. Justificando que ele ganhava pouco, ela propôs que ele parasse a venda de salgados e a acompanhasse à escola já que ela justificava ter medo de ir sozinha e dificuldades de manter-se na escola freqüentemente.

Daniela apresentou bom nível de compreensão, com vocabulário rico e correto em suas comunicações. Referia-se continuamente a mágoas e ressentimentos com relação a sua família de origem, inclusive caracterizando a mãe como pouco afetiva e distante. Afirmou ter sofrido abuso aos seis anos de idade, por pedreiros que trabalhavam em uma casa ao lado onde morava, fato que, segundo ela, não poderia ser contado para ninguém de sua família.

Ela passou por diversos serviços de Saúde Mental - NAPS, IAMSP (Instituto de Assistência Médica de São Paulo) e atendimento psiquiátrico com médico particular, alternando-os sem seguir nenhum por muito tempo. Interrompia os tratamentos sempre que era frustrada, o que ocorria pelo motivo recorrente de recusa do profissional em fornecer atestados médicos para ela apresentar no trabalho, para se afastar ou não receber as faltas cabíveis. 
No início do tratamento, tinha dificuldades em aderir ao PSF, procurando o serviço apenas para consultas, recusando-se a participar de qualquer atividade proposta por eles. Havia dez anos que Daniela não fazia consulta com ginecologista.

\subsubsection{1 - Síntese do Acompanhamento Terapêutico de Daniela}

$\mathrm{O}$ at foi solicitado pela agente comunitária e pela equipe do PSF devido a comportamentos de risco da paciente - não seguir tratamento medicamentoso prescrito por seus médicos de maneira correta, ingestão freqüente e, em alta dosagem, de medicamentos para dormir, dificuldade de adesão ao PSF, compras excessivas pela cidade sem ter condições de saldar suas dívidas e com a justificativa de que os livros nas prateleiras piscavam para ela.

Daniela foi atendida pela acompanhante terapêutica, no período de março a dezembro de 2004, inicialmente com dois encontros semanais e depois de três meses passouse a um encontro semanal. O AT não teve continuidade por desistência da cliente, posterior ao recesso de final de ano.

Durante os atendimentos, Daniela demonstrou interesse em conversar, mas em várias ocasiões saiu ou mandou falar que não estava em casa no horário do atendimento. A vontade de cuidar-se oscilava. Relatou, diversas vezes, que(,) apesar de ter medicação psicotrópica, não fazia uso correto dela por motivos que iam da falta de condições financeiras para comprá-los, até por acreditar que aquela medicação não era adequada para ela ou não lhe faria bem.

O trabalho do AT focou na reorganização de Daniela, relacionamento dela com o marido e com sua família, adesão aos serviços de saúde e ao tratamento medicamentoso proposto por sua médica psiquiátrica, a volta ao trabalho e envolvimento nele. 
Posterior à readaptação da paciente e rompendo o tratamento psiquiátrico com Ana Paula (médica psiquiatra particular que a atendeu por 18 meses), a paciente passou a utilizar mais do PSF, marcando consultas com o Dr. Adriano (médico generalista que atendia nesse serviço) sempre que precisava de um atestado para apresentar no trabalho pois utilizava de seus conhecimentos da lei estadual que dispunha de vários benefícios para os servidores estaduais, como faltas sem ocasionar descontos em seu salário mensal.

Percebemos também que, ao longo dos atendimentos, Daniela já não fazia uso freqüente de medicação abusiva para dormir, teve melhora em sua higienização pessoal não se apresentando para os atendimentos de camisola e despenteada, com reorganização dos gastos familiares de maneira comedida, inclusive com a preocupação de saldar as dívidas contraídas anteriormente.

Josué participou de alguns atendimentos, convidado pela at e, no período de setembro a dezembro de 2004, relatava algumas melhoras da paciente denunciando as oscilações de humor dela, ao longo da semana. Demonstrando para nós a necessidade de um atendimento prolongado para Daniela. Após o término dos atendimentos e com a recusa insistente de Daniela em atender a at, a agente comunitária foi orientada a estimulá-la a procurar o CAPS para seguir com o tratamento psiquiátrico e psicológico.

\subsection{2 - Categorias temáticas}

Exporemos ao leitor que nos acompanha relatos das entrevistas dos colaboradores-clientes com intuito de buscarmos em seus relatos as categorias que embasaram nossa análise compreensiva. 


\section{PERCEPÇÃO DE SI}

Tive grande melhora, já estou disposto (...) já estou cuidando da casa, agora estou com mais esperança (...) mais esperança de assumir a vida real (...) mais ainda tem uns pontos negativos (...) tem uns pontos negativos (...) que eu vou fazendo as coisas (...) eu fico retraído (...) tem umas coisas aqui na casa que eu fico retraído". (...) esse problema que vou mexer aqui ou lá eu não sinto bem, fico retraído (...) que eu passei por vários momentos difíceis e cheguei ao ponto de preparar o suicídio (...) depois de várias internações eu me recuperei um pouco (...) depois eu entrei na solidão, não queria conversa com ninguém, ficava trancado no quarto, sem conversar com ninguém sem se (me) alimentar (...). Me medicava por conta (...). Ari

Eu dou remédio pra eles pra eles, eu dou banho na minha mãe, é (...) eu ajudo a Marcolina (funcionária da casa), arrumo a cozinha prá ela assim, não é muito, tem dia que eu arrumo um tanto eu lavo mais é os pratos e talheres, sabe? (...) aí (...) enquanto ela lava (enquanto ela lava o restante) eu enxugo e guardo, eu enxugo não é que eu guardo, nem sempre é que eu guardo, às vezes é ela que guarda sabe (...) procuro tratar minha mãe, às vezes eu fico meio brava com ela, tratar bem (...) ah dá os remédios pra eles, dá comida, comida é a Marcolina que faz né (...) ela limpa a casa tudo (...) você Vânia.

Eu saía, fugia era muito preocupante (...) minha mãe ficava muito preocupada (...) a gente brigava eu e meu marido (...) e eu acabei fugindo com meus filhos, eu (...) eu entrei só em fria porque me hospedei no black stream, eles comeram tudo que tinha na geladeira e a conta ficou muito alta para você pagar (...). É (...) porque eu acho que eu não tenho nada, os médicos acham que eu tenho, mas no começo quando eu fui internada por alucinações, depois depressão e agora é transtorno afetivo bi-polar, (...) Elaine.

\section{HISTÓRIA DE VIDA}

(...) Eu tive uma infância muito feliz. Depois que cresci já fui coordenando minha vida normal, tive certas 'caídas' na minha vida, mas me recuperei, tive bons trabalhos e (...) depois assumi responsabilidade de uma união que eu convivi 40 anos com minha esposa, tive uma filha legítima com minha esposa outra adotiva (...). Com minha força de vontade que nunca faltou trabalho para mim (...) consegui criar minhas filhas, tinha uma vida estabelecida média, não era rico, mas era (...) tive uma pequena firma de raspação de taco e aplicação de sinteco onde trabalhei praticamente 45 anos. Tive uma vida estável média (...) Ari.

(...) chegou num ponto que aos 17 anos de casada não tinha mais nada a ver aí ele foi embora, ele tinha me batido e a polícia e meu irmão, pois ele para fora, ele foi embora e foi morar com outra (mulher) depois e só que levou meus filhos e eu não queria, queria que meus filhos tivessem ficado comigo, mas me ajudou o acompanhante terapêutico porque eu já tratava com a Dra Maria Lúcia (psiquiatra que iniciou seu tratamento) e não tinha saída, ela também ficava desesperada porque eu não tava ganhando dinheiro então como que eu ia pagar advogado para separar (...) então ela falava primeiro você precisa ganhar o seu dinheiro (...) Elaine.

\section{PERCEPÇÃO DA SITUAÇÃO}

Eu não falei que eu tô (...) escuta (...) o que que eu faço meu Deus? (...) eu não sei fazer essa entrevista (...) deixa eu ver meu Deus (...) o que que eu faço? Como é a pergunta que você fez? (...)Eu ia falar eu esqueci, ai meu Deus (...) aí eu eu não sei (...) é (...) é é terapêutico né (...) Vânia. 


\section{PERCEPÇÃO DO ACOMPANHAMENTO TERAPÊUTICO}

Da época que você começou a vir aqui (...) a situação que eu estava (...) agora eu estou bem melhor. Eu estava desanimado de tudo (...) As visitas da Dra Marciana eu tive grande melhora. (...) Hoje praticamente estou quase com uma vida normal (...) fico ansioso nos dias que a Dra Marciana marca que vem por que às vezes eu estou desanimado, deprimido (...) mas com as visitas dela eu já mudo meu comportamento (...) não sei como vou agradecer. (...), estou me sentindo bem melhor ou às vezes eu chego a pensar se é o medicamento ou se é o apoio que eu to tendo da Dra Marciana, do psiquiatra, da parte do posto de Saúde, da parte do hospital das clínicas que eu to sendo muito bem atendido (...) Ari.

É (...) eu acho bom (...) é (...) o acompanhamento ajuda a gente a ficar melhor até a vir a ser curada (...) é (...) eu me sinto melhor porque eu tomo os meus remédios e faço o tratamento direitinho e (...) e não me dá mais crises. Mas quando eu não tomava os remédios eu vivia internada porque me dava crises, eu fazia só coisa errada (...). O trabalho pode contribuir porque me faz sair mais de casa (...) sabe (...) eu caminho dia sim dia não então eu tô mais animada assim não tô mais sozinha eu sinto que eu tô (...) que tem gente que se preocupa comigo, então eu tô mais feliz (...) eu acho muito bom porque eu não fico sozinha (...) não fico isolada (...) tenho uma pessoa pra conversar. Elaine.

(...) é uma oportunidade de poder conversar sobre os problemas com uma liberdade maior e (...) e com um tempo não digo maior, mas com um tempo mais flexível (...) para mim foi assim durante o período que estive fazendo a terapia, na maioria dos casos, na maioria das vezes, melhor dizendo, ahhh eu me senti melhor (...) por isso eu acho que é importante fazer esse tipo de acompanhamento (...) a presença de uma pessoa que possa nos ouvir e nos dar uma resposta, não definitiva e completa, mas pelo menos nos dá um retorno daquilo que estamos falando, é importante. E com relação isso houve uma houve uma significativa melhora com relação a pelo menos aos períodos em que eu estive mais gravemente é ...) mais gravemente doente (...) Daniela.

(...) o pensamento (...) eu (...) os remédios o pensamento está melhor (...) acho que assim levanta, ajuda né (...) mas o que ajuda, o que ajuda mesmo é ter pensamentos positivos (...) Vânia.

(...) então, era bom quando você vinha aqui (...) eu gostava, eu gostei (...) (fala da at como alguém com quem precisava conversar) só que eu não queria me abrir. Eu não queria falar nada (...) eu não tenho nada (...), parece que você estava insistindo comigo (...) então eu agradeço a Deus porque (...) me ajudou, me orientou (...). Não foi só Deus, as pessoas que me ajudaram assim me encaminharam (...). Eu acho que você forçou um pouquinho de eu ir (para a internação hospitalar) (...) eu não queria ir (...) eu fiquei com raiva de você (...), eu não queria mais te ver (...) porque você forçou um pouquinho a barra, você (...) acho que foi você que fez meus irmãos me levarem não foi? (...). Eu sei que, eu sei que meus irmãos disse (disseram) que minha perna tava inchada e disse que viu que se não "coisasse" (cuidasse) ia cortar e eu podia correr risco de vida. (...) e então, eu achei que você forçou um pouquinho assim eles (...) porque parece que você telefonou, falando no telefone com uma outra pessoa e depois acho meu irmão, o Uvanildo, um gordo alto, de Sertãozinho, viu (...) você falou no telefone antes dele e depois você telefonou não sei pra quem e eu sei eles me levaram (...). Você cooperou né, porque você veio aqui, o Uvanildo fez umas perguntas pra você né, eu sei que você falou umas coisas pra ele (...) e eu não queria ir, e você e ele conversaram, né (...) eu não sei se foi pra me levar (...) e (...) e (...) a Marciana ela que falou com meus irmãos, você não falou com eles? Então, a Marciana ajudou falando com meus irmãos né (...) e, eu não sei se meu irmão, alguém orientou meu irmão quanto as minhas pernas ou como ele ficou sabendo que podia (...) que tava correndo risco né (...) Vânia. 


\section{ENFRENTAMENTO}

(...) Mas eu luto contra esses momentos de desânimo, de angústia ou é parte da vida que eu levo nesta solidão (...) Por que eu sinto uma vida muito desprezada por parte dos familiares - filhas - (...) por parte dos familiares sinto desprezado (...) Ari.

\section{PROJETOS}

Eu ainda estou vivendo sozinho, mas (...) (eu vou conseguir constituir nova família) (...) pretendo realizar meus sonhos (...) principalmente o problema da casa que eu estou (...). (está) correndo tudo bem, da maneira que eu espero, praticamente eu penso em ter uma nova união, apesar da minha idade, mais uns anos de felicidade é o que eu espero (...) Ari.

\section{PERCEPÇÃO DO OUTRO}

Por que parece que você estava insistindo comigo, (...) porque parece que tava insistindo né (...) você forçou um pouquinho de eu ir (...) eu não queria ir (...) eu fiquei com raiva de você (...) eu não queria mais te ver (...) porque você forçou um pouquinho a barra, você (...) acho que foi você que fez meus irmãos me levarem não foi? (...) eu achei que você forçou um pouquinho assim eles (...) porque parece que você telefonou, falando no telefone com uma outra pessoa e depois acho meu irmão, o Valdo, um gordo alto, de Sertãozinho, viu (...) você falou no telefone antes dele e depois você telefonou não sei pra quem e eu sei eles me levaram (...) e , não era você que (...) assim que forçou?(...) Vânia.

\section{PERCEPÇ̃̃O DO TRABALHO DO ACOMPANHANTE TERAPÊUTICO}

(...) era bom quando você vinha aqui (...) eu gostava, eu gostei (...) só que eu não queria me abrir, não é que eu queria me abrir, eu não tinha nada prá esconder, prá esconder, eu só não queria falar, (...) Vânia.

\section{2 - O familiar da pessoa em sofrimento psíquico}

\subsection{1 - Apresentando o familiar}

Apresentaremos os colaboradores-familiares com intuito de facilitar a compreensão de seus relatos e, posteriormente, apresentaremos fragmentos dos relatos das entrevistas.

Alendro, irmão de Ari, casado, aposentado. Morava com a esposa. O relacionamento com Ari era conflituoso. 
Vanildo, irmão de Vânia, morava com a esposa, no início do AT freqüentava a casa dos pais todos os dias e se ocupava da alimentação dos pais e de Vânia.

Da. Társia, mãe de Elaine, não quis participar da pesquisa. Mas por telefone sempre valorizou o atendimento da filha, afirmando que percebia a sua melhora.

Vagner, marido de Edivânia. Demonstrou interesse pelo AT e participou de vários atendimentos juntamente com sua esposa.

Da. Margarida, mãe de Sandra. Acreditava que nada mudaria sendo a filha, uma cruz que precisava carregar. Durante os atendimentos sempre reclamou de Sandra ressaltando os comportamentos negativos dela.

Josué, marido de Daniela, mantinha um relacionamento de submissão com a esposa. Era portador de enfermidade psíquica. Aceitava e compreendia Daniela, inclusive sem questionar as opiniões e decisões da esposa.

\subsection{2 - Categorias temáticas}

Exporemos ao leitor que nos acompanha fragmentos dos relatos dos colaboradores-familiares com intuito de facilitar nossa compreensão sobre a percepção e os sentidos que os familiares têm do Acompanhamento Terapêutico.

\section{PERCEPÇÃO DO PACIENTE PELO FAMILIAR}

(...) Ele (Ari) bebia muito (...) todos os dias 4 a 5 cervejas (...) Quando ele ficou aqui em casa, ele bebia. Ele fazia tratamento no $\mathrm{HD}^{20}$ e chegava em casa e bebia (...) Ele é muito manhoso (...) teve sempre tudo na mão. Eu tenho uma irmã que ajudava muito ele, mesmo depois de casado (...). Aleandro (irmão de Ari).

\footnotetext{
${ }^{20}$ Hospital-dia da Faculdade de Medicina de Ribeirão Preto - USP
} 
(...) tem dia que ela tá meio agitada tem dia que ela tá bem, tem dia que ela fala muita coisa tem dia que ela num fala nada, dia que ela fica alongada o dia inteiro no quarto (...). Ela tá meio é embirrada, ela não quer saber de trabalhar não (...) quer ficar à toa. Num que lavar panela, num que arrumar a cozinha, hoje eu arrumei toda a cozinha, ela acordou era nove e meia (...) ela era mais agitada, ela puxava a mão na vassoura, ela varria a casa ela passava pano, ela limpava o quintal (...), arrumava a cozinha, guardava tudo a louça agora ela tá mais devagar num tá com aquela força que ela tinha não. Não sei se é devido dos remédios que ela toma muito de manhã e toma de noite (...) ela não é uma pessoa que gosta de tá chique, ela não gosta de um relógio, ela não gosta de um anel, ela não gosta de um, de um colar, ela não gosta de um brinco, ela não gosta de nada disso. Ela tem as coisinhas dela que as meninas, as colegas dela tudo dá, lá no bailinho eles dão as coisas lá pra ela, só que ela não usa nada disso. Se ela usa um colarzinho ela tira, se ela vai com um relógio ela tira o relógio e põe na minha bolsa, ela não gosta de anel, ela não gosta de nada, de nada, nada, nada. É só esse short aí, se deixar ela vai desse jeito pro baile (...) ela fica o dia inteiro mole assim, o dia inteiro, nem arrumar mais a cozinha ela não quer. Para tomar um leite eu tenho que esquentar porque ela não quer, e ela fazia tudo sozinha, eu não me preocupava, ela esquentava comida, ela fazia, fervia o leite dela, esquentava o leite dela, tomava, ela sabia o horário direitinho, agora virou essa coisa aí, nem toma sozinha o café, nem esquenta (...) nada. É, É eu achei que os remédios estão deixando ela abatida (...), calma até demais (...) Margarida (mãe de Sandra).

(...) ela tem uma melhora por algum tempo, sabe assim, pouco tempo, mas logo em seguida ela, ela volta ao que era, então em outras palavras, um retrocesso (...) acho que ela tem uma melhora quando ela tem uma disposição de buscar por ela, uma melhora em prol lado dela, então eu acho que esse lado ajuda ela, mas normalmente quando ela fica na dependência, às vezes assim, do remédio ela não, não, não noto melhora nela (...) Vanildo (irmão de Vânia).

\section{HISTÓRIA DE VIDA}

A vida dele (...) ele começou, teve uma mulher (Pedrina), depois outra (Nilza) (...) duas filhas. Ele é trabalhador, mas boêmio. Depois que a mulher ficou doente (...) ele ficou (assim) e logo depois ele arrumou uma mulher (...) A Nilza teve um filho e, faz uns três meses que ele não manda pensão. (...) Ele separou da mulher (Nilza) eles brigavam muito (...) ele já foi usuário de droga também. Ele não se conformava em ficar sem beber. Ele foi mulherengo, teve uma vida sempre desregrada. (...) Ele bebia muito (...) depois ele ficou doente. (...) Ele gostava muito da mulher (Nilza), e (ele) adoeceu depois da separação (...) eles bebiam muito e brigavam (...). Aleandro (irmão de Ari).

(...) ela tinha uns nove anos, na idade dela mesma tinha uns nove anos. Porque na idade dela mesma que ela foi para a escola ela era mais (...). A Sandra ficou mais de 10/12 anos na APAE (Ficou na APAE dos 9 anos até 19/21 anos, não conseguimos averiguar o tempo certo de permanência da Sandra nessa escola). Eu tinha um documentário, não sei onde guardei, ela entrou na Apae antes de 1973 ficou até (...) ela mesma que quis sair, ela não quis continuar, ela falou que não queria ficar lá, que não (...) queria ficar mais (...). Margarida (mãe de Sandra).

\section{OS TRATAMENTOS}

(...) Ele fez tratamento no $H D$, no $H C^{21}$, no S. Vicente de Paula ${ }^{22}$. (...) Ele teve no NAPS ${ }^{23}$ também e brigou lá com o Dr Aroldo, agora ele tem consulta com o Dr Laércio (...) Ele fez tratamento no HC, no S. Vicente de Paula, no NAPS e no posto da Vila Tibério ele trata até hoje (...) Aleandro (irmão de Ari).

\footnotetext{
${ }^{21}$ Hospital das Clínicas de Ribeirão Preto.

${ }^{22}$ Sanatório Espírita São Vicente de Paulo.

${ }^{23}$ Núcleo de Atenção Psicossocial - Ribeirão Preto.
} 
(...) ela foi melhorando (...) ela se sentia melhor com o remédio, com o medicamento quando eu conheci ela (...) já fazia tratamento e então ela foi melhorando, melhorando, melhorando e (...) parou (...) a melhora e depois retrocedeu (...) não teve aquela melhora definitiva, ela voltou a ficar ruim de novo (...) melhorou ficou (...) Josué (esposo de Daniela).

(...) quando ela foi levada assim amarrada, forçada para o hospital foi, foi uma coisa boa pra ela aquilo, se não tivesse feito, se ela não tivesse sido medicada, não tivesse sido tratada podia ter complicado a vida dela. E (...) a partir disso ela ficou internada (...) né (...) no Santa Tereza e (...) e depois de um certo tempo ela voltou, ela continuou a querer fazer esse tratamento (...) eu senti essa disposição (...) Vanildo (irmão de Vânia).

\section{PERCEPÇÃO DO TRATAMENTO}

\section{Percebendo a mudança}

(...) Agora com o seu trabalho, com o tratamento ele foi melhorando (...) hoje com o seu acompanhamento ele está uns $90 \%$, não vou por $100 \%$ pq às vezes ele não está bem (...), mas ele está bem, fazendo sua comida, cuidando de suas coisas e agora está cuidando da neta (...) Ele tá bom, tá ótimo eu arrumei umas ferramentas para ele e ele tava fazendo uns brinquedinhos, porta vaso (...) Aleandro (irmão de Ari).

(...) foi um período que eu notei que ela se interessou (...) com relação ao tratamento, eu vi um período que ela demonstrou assim um interesse de fazer, de se cuidar (...). Ela melhorou, parece que a disposição dela (mudou). (...) ela hoje (...) eu vejo que ela ta retrocedendo (...) Vanildo (irmão de Vânia).

\section{Percebendo a especificidade do tratamento em saúde mental}

(...) Bom é o jeito dela né (...) no dia-a-dia ela muda (...) por exemplo o tratamento está sendo feito de uma forma né (...) ela (...) ta agradando ela , ela tá se sentindo bem com o tratamento, então parece que ela vai (..) que tá melhorando e e aí (...) de uma hora para outra aquilo ali desaparece, aquela melhora desaparece (...) parece que o tratamento não tá servindo de nada, mas na verdade tá sim é claro, nós sabemos disso, mas aparentemente (...) parece que está paralisado (...) Josué (marido de Daniela).

\section{Participando da melhora do paciente}

Ela teve uma melhora de cem por cento do que ela tava passando até hoje ela melhorou bastante (...) em todo o sentido tanto nas crises que ela tava naquela ansiedade de querer sair toda hora (...) Foi quando eu comecei a dar atenção e espaço para ela, que você tinha conversado com a gente e eu comecei a dar um pouco mais de espaço pra ela, comecei a conversar com ela e a gente começou a conversar ali, aqui e foi acertando os pontos que estavam faltando do quebra-cabeça (...) ela melhorou pra mim em todos os aspectos (...) de pouquinho em pouquinho ela foi melhorando, (...) a gente foi dando uns espaços para ir acertando o que estava errado e (...) sempre estava do lado dela conversando, acompanhando (...) ela queria sair ela chamava para sair - "ah vamo dá uma volta, preciso dar uma volta" -, pegava ia dá uma volta, punha (o nenê) no carrinho, pegava ia aqui na Avenida do Café dar uma volta, então foi trocando isso ai por a gente caminhando à noite, conversando, acertando, então ela foi (...) Vagner (marido de Edivânia). 


\section{Demonstrando a dificuldade em cuidar do outro}

(...) eu acho que na parte psicológica ajudar (ajudou na conscientização) você precisa se cuidar eu acho que você ajudou ela bastante nesse sentido de despertar nela esse interesse de se cuidar, isso é importante, chegou o ponto que ela nem queria se cuidar. Se cortasse a perna dela (...) deixa cortar era isso que ela falava (...). Não comia, tava fazendo as necessidades no quarto, no corredor e não tava nem aí porque aquilo que tava agindo na cabeça dela, tava fazendo tudo isso (...) faz isso, faz aquilo, não tinha paz, não tinha sossego (...) Vanildo (irmão de Vânia).

\section{Apresentando a dificuldade em aceitar a melhora do outro}

(...) noto pouca diferença, pouca diferença. ela é (...) pus bailim (baile que acontece em uma casa, no bairro em que mora) dela que ela gosta de ir, isso ai eu notei uma diferença porque antes eu não levava ela, ela ficava aqui, só que, depois eu levei ela uma vez, duas (...), pronto, agora ela sai sozinha e vai (...), ela gosta de dançar de, de, de conversar só que (...) eu do jeito assim dela teve pouca diferença (...) Margarida (mãe de Sandra).

\section{3 - Agentes comunitárias}

\subsection{1 - Apresentando a agente comunitária}

Antes de expormos as categorias das agentes comunitárias, faremos uma sucinta apresentação dessas colaboradoras.

Elizandra - atua como agente comunitária desde dezembro de 2000. É responsável pelo atendimento da família de Edivânia

Heloísa - desempenha as atividades de agente comunitária desde dezembro de 2000. Encaminhou alguns pacientes de sua área para AT, mas nenhum deles participou como colaborador dessa pesquisa.

Gabriela - trabalha como agente comunitária desde junho de 2001. Em sua área de abrangência acompanha a casa de Sandra e Elaine.

Érica - desenvolveu as atividades como agente comunitária de junho de 2001 até março de 2006, sua saída foi decorrente da mudança de residência, o que impossibilita a 
agente de atender naquele bairro já que como exigência do serviço elas têm que residir na abrangência do PSF. Atendia a família de Ari e Vânia.

Juliana - trabalha como agente comunitária desde maio de 2003. Em sua área de abrangência atende a família de Daniela.

\subsection{2 - Categorias temáticas}

\section{PERCEPÇÃO DO TRABALHO COM O INDIVÍDUO PORTADOR DE SOFRIMENTO PSÍQUICO}

(...) eu acho que dessa forma do jeito que você chega, do jeito que você é recebida, desde o primeiro momento, então eu acho que a partir daí até nas próximas visitas você vai ver como vai ser, por que um dia ele vai te receber bem, um dia o outro não recebe, um dia a família quer que você não bata no portão (...) então eu acho que isso (...) eu acho que isso vai (...) assim evolui, às vezes (...) Gabriela.

\section{EXPECTATIVAS DO TRABALHO DO ACOMPANHANTE TERAPÊUTICO}

No caso especifico do Ari o seu Acompanhamento Terapêutico foi muito esperado, né. Eu esperava muito e pedi muito (...), durante muito tempo vinha já sendo acompanhado (pela equipe do PSF) desde (...) inicio de 2001, era paciente que todo mundo já conhecia e era assim a gente já tava esgotando (...) Érica.

\section{Sentindo-se perdida}

(...) a gente já tava esgotando, já tinha esgotado todas as tentativas, todos os meios e tava ficando cansativo, eu mesmo tava me vendo perdida (...) tudo que fazia, nada dava resultado (...) Érica.

\section{PERCEPÇÃO DO TRABALHO DO ACOMPANHAMENTO TERAPÊUTICO}

(...) Sr. Ari melhorou muito depois desses acompanhamentos (...). È muito importante (...). É muito válido, é muito bom, a gente vê resultado assim nítido, não precisa ta vendo nem através de exames, a gente vê, a gente sente que as pessoas melhoram bastante. Lógico, tem assim tem aquelas quedas, melhora, cai, levanta, mas eles estão sempre buscando, tá sempre assim com aquela esperança e com isso as coisas vão melhorando, o jeito deles, muda o comportamento (...) é (...) eles aprendem, captam muita coisa de bom pra eles (...) Heloísa 
(...) deve ajudá-los a esclarecer um pouco, a perceber as coisas, a tentar definir o que tá havendo, (...) a tentar se organizar dentro daquilo que ele precisa, dentro daquilo que ele tá precisando no momento (...) a tentar fazer ele se organizar, (...) acontecendo, o que tá pegando (...) pró paciente, com certeza, deve ter ajudado bastante (...) pra nós também, porque daí forma aquele vínculo (...) para o paciente eu acho que ajuda bastante (...) pra abrir um pouco os caminhos, pra ver qual é a dificuldade daquela pessoa, o que tá acontecendo, eu acho que é um atendimento mesmo (...) que é uma ajuda, é uma coisa a mais além do que já se pode ter (...) Elizandra.

(...) depois com a entrada do acompanhamento eu acho ele melhorou muito, muito mesmo, por mais que ele caia hoje, ele não tem mais aquela depressão que ele tinha antes. Antes ele tinha aquela coisa de não sair mais de casa, não fazer nada, não comer, não tomar banho, achar que a vida dele tava perdida, e hoje não mais, hoje ele tem os momentos de tristeza, de solidão de achar que ninguém quer, de que ele não tem felicidade, mas não tem mais aquela coisa, ele reage, (...) o seu acompanhamento fez com que, ele foi ao NAPS (atual CAPS) coisa que a gente nunca conseguiu, a gente não conseguia de jeito nenhum, ele não aceitava ele não ia (...) Érika.

(...) Como eu percebo? Ahhh eu acho que ajuda bastante. Assim (...) acho que você indo, acompanhando tando dentro de onde ele vive, da situação, vendo do ambiente tudo acho que ajuda bastante, acho que (...) no dia-a-dia você vai viver com ele aquela situação, né? Porque você chega lá, vai ta dentro do ambiente dele né. Aí ali você vai descobrir coisas que talvez no consultório você não consegue identificar (...) eu notei em determinados casos que começou a ter o acompanhamento terapêutico o que que aconteceu eles abrem aquele mundo deles que é fechado (...) então eu noto essas coisas que melhoram, por exemplo a Sonia não (...) era direto falando palavrão né, e eu acho que ela melhorou (...) Gabriela.

\section{Percebendo a melhora no tratamento a partir do trabalho do acompanhante terapêutico}

(...) as pessoas que às vezes não tinha esperança nenhuma hoje já pensa, sabe, que quer viver mais, que quer melhorar mesmo que a gente saiba que às vezes uma doença não vai ter mais cura, pq às vezes já virou crônica, não tem mais solução (...), mas, pelo menos, eles ficam motivados e com vontade de viver (...) Heloísa.

(...) ele já tava num processo de melhora porque antes, no inicio ele (Ari) dava muito trabalho tinha vez que ele não conseguia sair, por diversas vezes eu fui na casa dele, assim ele não conseguia sair nem no portão ele tinha medo, (...) ninguém ligava para ele, ninguém gostava, a gente ia lá (...) Érica.

(...) ela já abre, quer que você entra, e insiste, aí o dia que você passa e só fala um oi ela fica diferente também, aí você muda até o seu jeito de tratar, porque você consegue identificar como você pode tratar um e como você pode tratar o outro (...) eu acho, quando começou com a Sandra sem ir direto com a $D$. Margarida (...) eu acho que no fim, a D. Margarida participou mais, às vezes, do que até a Sandra. E essa participação da D. Margarida influenciou a Sandra. Por quê? Melhorou (...) eu acho que essas coisas quando você começou a trabalhar (se refere ao trabalho da AT) isso quando a Sandra vinha queixar ou falar, não sei forma, né, como que usou, mas assim, ela (...) acho que amenizou tanto a briga com as duas (entre mãe e filha) (...) Gabriela. 


\section{Acolhendo o paciente}

(...) mesmo que às vezes eles nem seguem direito, não fazem o que a pessoa pede, que orienta, mas pelo menos eles têm com quem contar (...) com aquela pessoa, e pra muitas pessoas isso foi muito bom (...) Heloísa.

(...) tem a Dra. Marciana no pedaço, tem a Gabriela (agente comunitária) (...) Gabriela.

\section{Abrindo-se para o outro}

“(...) E eu acho que depois que começou assim, além das visitas, por que no início pra visitar era difícil também, (...) eu acho que depois que começou assim, além das visitas, por que no início pra visitar era difícil também, por que eu passava, olhava e falava oi (...) e ela: (respondia) oi e eu não entrava porque (...) (tem) síndrome de Down mora, tá sozinha em casa, vai que acontece alguma coisa pode achar (...) o dia que você passa e só fala um oi ela fica diferente também, aí você muda até o seu jeito de tratar, porque você consegue identificar como você pode tratar um e como você pode tratar o outro (...) Gabriela.

\section{A PERCEPÇÃO DO TEMPO NO TRATAMENTO}

(...) daí um tempo, (...) daí um período (...) dependendo do caso, nem seja necessário mais (...) (atendimento psicológico) por ter assim, resolvido mesmo sabe posto a esclarecer mesmo as coisas (...) Elizandra.

(...) na realidade dava (o paciente tinha melhora), só que era aquele resultado lento que a gente não percebe muito, a gente costuma perceber só os resultados mais evidentes mesmo (...) Érica.

(...) às vezes pode até você achar que aí não tá adiantando nada, né, em determinada visita ou determinado acompanhamento (...) aí depois você vai ver que no final assim, dum certo tempo, você vê como muda as coisas (...) Gabriela.

\section{PERCEBENDO A SOLIDÃO DO OUTRO}

(...) esses problemas (...) que não tem com quem conversar, que nunca tem um familiar que, (...) eles sentem uma necessidade muito grande de ter alguém pra poder tá falando (...) Heloísa.

\section{VÍNCULO PROFISSIONAL-PACIENTE}

(...) a pessoa já te espera, já fica brava se você não vai, cobra de você, (...) então eu acho que ela cria, ela cria um vínculo que ela acha que é uma pessoa que vai lá pra tá ajudando (...) a pessoa já te espera, já fica brava se você não vai, cobra de você, (...) então eu acho que ela cria, ela cria um vínculo que ela acha que é uma pessoa que vai lá pra tá ajudando (...) ele (a paciente e, muitas vezes o familiar também) abre (conta) tudo prá você, então fala tudo de coisas mais íntimas às vezes começa abrir, tá falando dos problemas que tem na família e vai te colocando (...) Gabriela. 


\section{INSEGURANÇA}

(...) você fica numa certa corda bamba (...) Gabriela.

\section{IMPORTÂNCIA DO TRABALHO DO ACOMPANHAMENTO TERAPÊUTICO}

(...) é muito bom, é muito importante, eles se sentem bem com essa presença, por que eles gostam de falar muito, de contar de seus problemas, de ouvir também a gente. Eles ouvem muito a gente e acaba melhorando a vida, a vida fica mais (...) fica menos pesado (..., pra eles (...) Heloísa.

(...) é importante o acompanhamento terapêutico, eu acho que muitas pessoas assim se beneficiam disso né, assim pelo menos como ponto de partida dela tá saindo de casa, tá indo participar em grupo ou tá indo até para procurar o serviço (...) eu acho que devia ter mais acompanhantes terapêuticos, mais profissionais que se interessem por acompanhamentos terapêuticos (...) Gabriela.

(...) Pra pacientes como ele (Ari) era, eu acho que é essencial, acho que o cuidado, só o nosso cuidado aqui que é cuidado de saúde não é suficiente, não era tanto que essa melhora aparente dele, maior só veio depois do acompanhamento (AT) porque antes às vezes a gente se via perdido. Eu acho que é necessário, é um elo necessário. A gente precisa de apoio mesmo pra esses pacientes (...) Érica 
6 - DESVELANDO OS SENTIDOS DO ACOMPANHAMENTO TERAPÊUTICO 
Neste momento do trabalho, é necessário analisar os depoimentos do portador de sofrimento mental, do seu familiar e do agente comunitário que o atende.

Após organizar as unidades de significado em categorias, buscamos compreendêlas pela leitura fenomenológica dos relatos pessoais obtidos com as entrevistas e, com dados dos atendimentos realizados pela at. Nesse sentido, traremos fragmentos de seus relatos e algumas informações dos atendimentos em AT, com esse intento, tomaremos como eixos norteadores o acompanhamento terapêutico, a reabilitação psicossocial, a reforma psiquiátrica e a Psicologia Fenomenológico-Existencial.

\section{1 - A compreensão se desvela nos discursos}

\subsection{1 - A pessoa em sofrimento psíquico}

Acreditamos que o homem é o único ser capaz de, refletindo, ressignificar suas escolhas e modos de ser, estabelecendo relacionamento com os outros, mais autênticos e satisfatórios.

Com esse intuito, discorreremos sobre fragmentos dos relatos dos nossos entrevistados, visando compreender a percepção que os colaboradores desta pesquisa têm do acompanhamento terapêutico para o tratamento do portador de sofrimento mental.

As categorias selecionadas foram as seguintes: percepção de si, história de vida, percepção da situação, percepção do acompanhamento terapêutico, enfrentamento, projetos, percepção do outro, percepção do Acompanhante Terapêutico. 


\section{$1^{\text {a }}$ categoria: Percepção de si}

O colaborador, Ari, relata a dificuldade de lidar com seu retraimento frente a algumas situações, demonstrando impaciência quanto à duração do seu tratamento e com as mudanças, em seu comportamento decorrentes da depressão. Refere-se, também, aos momentos difíceis pelos quais passou, como a solidão e as idéias suicidas, como podemos ver abaixo:

(...) tem uns pontos negativos que eu vou fazendo as coisas (...) fico retraído (...). Tem umas coisas aqui na casa que (...) fico retraído (...). Esse problema que vou mexer aqui ou lá eu não sinto bem, fico retraído (...), quero saber se isso é devido à queda emocional que eu tive (...). Passei por vários momentos difíceis e cheguei ao ponto de preparar o suicídio (...) depois de várias internações eu me recuperei um pouco (...) Ari.

Percebemos a fragilidade e a vulnerabilidade demonstradas nos momentos em que Ari se depara com a doença mental que o aprisiona em sua vontade e agilidade frente à vida. Nesse sentido, observamos uma paralisação e incapacidade de se cuidar, seja seguindo o tratamento psiquiátrico proposto, com o uso correto da medicação e visitas regulares ao médico, seja na participação nas atividades do CAPS, tendo maior oportunidade de socialização.

Uma outra experiência é de Edivânia que demonstra uma percepção de si, que, ao mesmo tempo em que tem uma leitura assertiva de suas dificuldades, também expressa incapacidade de buscar ajuda sozinha, como vemos em seu relato.

(...) foi a época que eu mais precisei, então eu lamento por não ter conhecido (ter sido atendida pela at) no início, ter tido ajuda no início, foi mais no final (da gravidez) (...) só que não era só repouso que me ajudaria (...) no início da minha gravidez porque foi a época que eu mais precisei, que foi muito importante (...) antes disso eu queria uma pessoa, né, que me entendesse, não ficasse me criticando, nem me debatendo (...) então era que me levava os motivos de eu sair desesperadamente, porque eu não tinha com quem conversar (...) Edivânia.

A colaboradora Vânia ressalta um outro aspecto quando relata suas atividades cotidianas e descreve uma maneira de ser que reconhece suas limitações e as aceita. 
Reconhece-se capaz de ajudar nas atividades domésticas, mas incapaz de realizá-las totalmente, porém, sem se importar com isso, favorecida por um olhar para as suas capacidades reais e não para as que perdeu ou, ainda, as que gostaria de ter.

(...) Eu dou remédio pra eles (para os pais), eu dou banho na minha mãe, é (...) eu ajudo a Marcolina (funcionária da casa), arrumo a cozinha prá ela assim, não é muito, tem dia que eu arrumo um tanto eu lavo mais é os pratos e talheres, sabe? (...) enquanto ela lava (enquanto ela lava o restante) eu enxugo e guardo, eu enxugo não é que eu guardo, nem sempre é que eu guardo, às vezes é ela que guarda sabe (...) procuro tratar minha mãe, às vezes eu fico meio brava com ela, tratar bem (...) é (...) dá (...) ah dá os remédios pra eles, dá comida, comida é a Mariana que faz né (...) Vânia.

Sandra também demonstra aceitação de sua condição e enfatiza dificuldades e incertezas de todo ser humano como levantar cedo, cuidar dos seus dentes, escová-los, e até mesmo perdê-los (teve que arrancar os dentes da arcada superior devido à má higienização, na arcada inferior tem cinco dentes). Essa colaboradora relata a sua dificuldade em lidar com situações cotidianas, que fazem parte da vida de todo ser humano adulto, como levantar de manhã, escovar os dentes, cuidar deles, fazendo higienização, para cuidar da saúde bucal e estética, como vemos abaixo:

(...) pra mim, se eu levantasse de manhã é duro né, mas eu preciso levantar, eu preciso escovar o(s) dente(s) (...), a preguiça também (...) pra escovar o dente (...) eu tenho medo que machuca (...) Sandra.

Essa colaboradora, apesar de ter habilidades em crochê, nem sempre tem material para executar a atividade, o que poderia ser resolvido por uma maior participação familiar, incentivando-a a desenvolver habilidades e, assim, além de se perceber capaz e útil, poder lhe propiciar novas maneiras de inserção na comunidade.

(...) pra fazer crochê é duro também, eu gosto de fazer crochê(,) mas não tem pano (linha e pano de prato para fazer bicos) (...) Sandra.

Um exemplo dessas habilidades pode ser visto, depois de alguns meses de AT, nas rodas de crochê que fazia, no grupo de artesanato, e as desmanchava porque não sabia o que fazer com elas e, também, não conseguia fazer um trabalho maior. Vendo sua dificuldade, 
uma colega desse grupo juntou sua produção em uma almofada que nossa colaboradora mostrava a todas as visitas que chegavam à sua casa. Sua permanência nesse grupo de atividade possibilitou ir além e se lançar para fazer uma toalha maior, com alguma dificuldade, mas com muito incentivo ela tem conseguido ampliar suas rodas de crochê.

Elaine, por outro lado, relata um modo deficiente de ser em que, sem reconhecer suas limitações emocionais em cuidar de si e dos filhos, foge buscando abrigo em um hotel, escondida de todos, criando uma situação constrangedora para si mesma, seus filhos e sua família. Em um momento-limite de sua angústia, não consegue pedir ajudar para os familiares e/ou profissionais já que estava em tratamento terapêutico com uma médica psiquiatra.

Eu saía, fugia era muito preocupante (...) minha mãe ficava muito preocupada (...) a gente brigava eu e meu marido (...) e eu acabei fugindo com meus filhos, eu (...) eu entrei só em fria porque me hospedei no Hotel (de alto padrão), eles comeram tudo que tinha na geladeira e a conta ficou muito alta para você pagar (...) Elaine.

Observamos que Elaine não conseguiu, naquele momento, estabelecer contato com o outro - seu marido - fugindo com os filhos e, mesmo com eles, se relacionou de maneira inadequada, se hospedando em um hotel sem ter condições para pagá-lo, e sem se preocupar com a alimentação e as necessidades dos filhos e dela. A enfermidade mental de Elaine a colocou distante tanto do marido como dos seus familiares, deixando-a sozinha.

Ao longo dos AT, percebemos a explicitação da falta de comunicação, em via de mão dupla, entre Elaine e seus familiares, denunciando, inclusive, o rompimento dessa comunicação. A saída dela de casa é entendida, por nós, como expressão de intenso sofrimento e total incapacidade de manifestar esse sofrimento de uma maneira que a aproximasse de seus familiares. Beaini (1981) ressalta por meio da linguagem que o homem mostra-se ao outro permitindo o relacionamento com os outros ao seu redor. 
Evidenciamos, ainda, que sua família não demonstrou capacidade de vê-la e ouvila em seu sofrimento o que favoreceu esse distanciamento. $O$ agravamento de sua enfermidade denunciou a incapacidade de se autocuidar.

A partir de pesquisas com crianças com câncer, Valle (1997) tece algumas considerações a respeito desse sofrimento humano. Corroboramos, com essa autora, que o ser humano pode viver seu adoecimento com revolta ou resignação, com recusa ou aceitação, pode expressar atitudes irracionais e absurdas ou conscientes e amadurecidas, autêntica ou inautenticamente e, portanto, impossível separar o sujeito de sua doença. O adoecer é vivido pelo indivíduo doente como uma experiência pessoal de desordem que adquire um sentido único e particular nesse momento existencial.

\section{$2^{\mathrm{a}}$ categoria: História de vida}

Como condição de existente no mundo, Ari se percebe como homem-casado-paitrabalhador e se relaciona como ser temporal envolvido com sua finitude existencial. Em seu relato, demonstra essa compreensão de um indivíduo vivendo no seu tempo, com uma seqüência lógica dos fatos que marcaram sua vida.

(...) Eu tive uma infância muito feliz. Depois que cresci já fui coordenando minha vida normal, tive certas 'caídas' na minha vida, mas, me recuperei, tive bons trabalhos e (...) depois assumi responsabilidade de uma união que eu convivi 40 anos com minha esposa, tive uma filha legítima com minha esposa, outra adotiva (...) é, (...) outra adotiva. Com minha força de vontade, (...) nunca faltou trabalho para mim. Sempre agradeci a Deus e todas bênçãos divinas. Consegui criar minhas filhas, tinha uma vida estabelecida média, não era rico mas era (...) tive uma pequena firma de raspação de taco e aplicação de sinteco onde trabalhei praticamente 45 anos. Tive uma vida estável média (...) Ari.

Um aspecto importante aparece nos relatos de Elaine quando explicita, em sua história de vida, o desencontro com o outro. Muitas vezes, a enfermidade mental está relacionada a esse desencontro. Nossa colaboradora traz, em seus relatos, o distanciamento do marido devido a alucinações e a pensamentos delirantes, o que provocava várias brigas e até 
atos de violência entre eles, trocados por ambos. O relato a seguir explicita uma cena dessa violência, dele contra ela:

(...) chegou num ponto que, aos 17 anos de casada, não tinha mais nada a ver (nós dois juntos), aí ele foi embora, ele tinha me batido e a polícia e meu irmão pôs ele para fora, ele foi embora e foi morar com outra (mulher) (...) só que levou meus filhos e eu não queria, queria que meus filhos tivessem ficado comigo (...) Elaine.

Maria Lúcia, médica psiquiatra de Elaine, a ajudou a compreender sua dependência financeira do marido como impeditivo real para uma separação, o que nossa colaboradora não conseguia perceber sozinha, pela dificuldade em planejar e executar ações, que aventamos ser devido à angústia que vivenciava naquele momento.

(...) Dra. Maria Lúcia (psiquiatra que iniciou seu tratamento) (...), ela também ficava desesperada porque eu não tava ganhando dinheiro então como que eu ia pagar advogado para separar (...) então ela falava primeiro você precisa ganhar o seu dinheiro Elaine.

Esse desencontro com as pessoas ao seu redor é relatado por Edivânia:

(...) eu tava grávida, tinha (...) fiquei deprimida. E, ninguém conseguia me entender (...) Assim, eu precisava falar muito de (...) eu não tinha com quem conversar (...) Edivânia.

Essa colaboradora demonstra a necessidade de falar, desabafar, ser ouvida, ser compreendida, mas explicita a incapacidade de construir ou buscar uma relação pautada na troca, na afetividade, enfim, uma relação mais amadurecida.

\section{$3^{a}$ categoria: Percepção da situação}

Vânia demonstra sua dificuldade com a entrevista. Inicialmente tinha concordado em participar após a pesquisadora ter explicado sobre o que versaria a entrevista e como ocorreria. A experiência de falar sob o olhar de um outro, um gravador, é uma proposta pouco comum para ela. Este momento foi vivenciado por Vânia com aflição do "não saber fazer" que deu lugar à insegurança. 
Eu não falei que eu tô (...) escuta (...) o que que eu faço meu Deus? (...) eu não sei fazer essa entrevista (...) deixa eu ver meu Deus (...) o que que eu faço? Como é a pergunta que você fez? (...) Eu ia falar eu esqueci, ai meu Deus (...) aí eu eu não sei (...) é (...) é(...) é terapêutico (...) Vânia.

Vânia abriu espaço para se lançar e, nesse processo, descobrir-se fazendo e, assim, possibilitou o encontro com o outro pelas suas necessidades. Dessa maneira, interagiu e transformando a si e ao outro, construindo novas possibilidades de ser.

\section{$4^{o}$ categoria: Percepção do acompanhamento terapêutico}

Percebemos, ao longo dos atendimentos, que Ari encontrava dificuldades para ser cuidado, para confiar e seguir as prescrições dos médicos que o atendiam. A entrada da at auxiliou no estabelecimento de uma relação de confiança entre equipe e usuário, favorecendo a adesão ao serviço e seu comprometimento com o tratamento, possibilitando a melhora do seu quadro depressivo com apresentação de comportamentos mais sadios. Permitiu, também, uma abertura, um encontro consigo mesmo a partir da vivência cotidiana.

Da época que você começou a vir aqui (...) a situação que eu estava (...) agora eu estou bem melhor. Eu estava desanimado de tudo (...) (com) as visitas da Dra. Marciana eu tive grande melhora. (...) Hoje praticamente estou quase com uma vida normal (...), estou me sentindo bem melhor ou às vezes eu chego a pensar se é o medicamento ou se é o apoio que eu to tendo da Dra. Marciana, do psiquiatra, da parte do Posto de Saúde, da parte do hospital das clínicas que eu to sendo muito bem atendido (...) Ari.

Ari perdeu o sentido de sua vida, explicitando o esvaziamento que a depressão representa para o ser humano. Dessa maneira, sentia-se triste e desanimado; acreditava que nada havia a ser feito. Nesse momento, a at trabalhou como ego auxiliar ${ }^{24}$ ajudando-o com o intuito de fortalecer, a si mesmo, para conseguir um relacionar-se-com-o-outro de maneira autêntica. Isso foi feito por meio da escuta e da ação, construindo com ele a organização do seu tempo, do seu espaço físico, de suas roupas, da sua higiene pessoal, de sua alimentação e ingestão da medicação de maneira correta com a prescrição médica.

\footnotetext{
${ }^{24}$ Ação do terapeuta que assume funções que o cliente não consegue realizar, naquele momento sozinho.
} 
O discurso de Elaine retrata a conscientização que a at ajudou a formar para a necessidade dela se reconhecer como ser-enfermo-mental com necessidades de ingestão de medicação psicotrópica da maneira prescrita por seu médico e participar nos grupos de atividades no CAPS, favorecendo uma organização emocional mais ajustada e, assim, maior e melhor relacionamento interpessoal.

(...) eu acho bom (...) é (...) o acompanhamento ajuda a gente a ficar melhor até a vir a ser curada (...) é (...) eu me sinto melhor porque eu tomo os meus remédios e faço o tratamento direitinho e (...) e não me dá mais crises. Mas quando eu não tomava os remédios eu vivia internada porque me dava crises, eu fazia só coisa errada (...) O trabalho pode contribuir porque me faz sair mais de casa (...) é (...) sabe eu caminho dia sim, dia não, então, eu to mais animada assim não to mais sozinha eu sinto que eu to (...) que tem gente que se preocupa comigo, então eu to mais feliz (...) Elaine.

Daniela ressalta a maior disponibilidade da at para ouvi-la e conter suas angústias, o que possibilitou significativa melhora em seu equilíbrio emocional. Afirma sentir-se melhor, atribuindo isso a sentir-se acolhida com o atendimento que representou para ela ter mais flexibilidade e disponibilidade.

(...) é uma oportunidade de poder conversar sobre os problemas com uma liberdade maior e (...) e com um tempo não digo maior(,) mas com um tempo mais flexível (...) para mim foi assim durante o período que estive fazendo a terapia (AT), na maioria dos casos, na maioria das vezes, melhor dizendo, ahhh eu me senti melhor (...) por isso eu acho que é importante fazer esse tipo de acompanhamento (...) Daniela.

Atuando como agente socializador, o at, muitas vezes, exerceu o papel de ponte entre o acompanhado e o outro - familiar, amigo, comunidade, serviço de saúde -, favorecendo um campo para (re)descobrir oportunidades e possibilidades para o enfermo psíquico.

Para cuidar do acompanhado, o at se imbuiu de um desejo verdadeiro de estar com o outro na sua dor, na enfermidade e na sua limitação, já que em muitos momentos ele sentiuse sozinho, o que propiciou uma proximidade que favoreceu a vinculação acompanhadoacompanhante e, assim, o tratamento. Como pode ser visto com Ari, Daniela, Elaine, Sandra, Edivânia. 
Essa sensibilização ocasionou ao at e à equipe de saúde que os atendem, pensar um projeto terapêutico com reais possibilidades de ampliação dos seus movimentos, desenvolvimento de suas habilidades o que capacitou que eles, cada um a seu modo e a seu tempo, se apropriasse de seu mundo, estimulando novas e mais adaptadas maneiras de viver.

Na saúde mental, o uso de psicotrópicos age sobre os sintomas que se apresentam como delírios, alucinações, depressão, ansiedade, mania, agressividade entre outros, mas, mais do que o indivíduo em uso de remédios psicotrópicos, é preciso vê-lo como ser humano inserido no mundo. O profissional de saúde - médico, enfermeira, técnico, agente comunitária ou acompanhante terapêutica — é um co-agente que participa do tratamento desse ser-em-sofrimento-mental e, como tal, pode cuidar significativamente na solicitude, implicando co-existência e participação.

Para esse cuidado, é preciso ajudar o ser-enfermo psíquico a se abrir às outras possibilidades de se relacionar que perpassam a singularidade do ser humano, do que somente aquelas que se encerram na relação sujeito-objeto.

As falas dos colaboradores evidenciaram a at de diferentes modos por cada um deles e, também, com diversas conotações ao longo do atendimento, como exemplificamos nas linhas que seguem.

Vânia relata que inicialmente percebe o at como intruso e alguém que quer fazê-la tratar de algo que não acredita precisar, crendo que a at a faria falar de si mesma sem ela querer, não percebendo que os atendimentos já estavam acontecendo. Percebemos, também, uma confusão entre o não querer falar e o perceber a at como intrusa e insistente. Posteriormente, essa colaborada demonstra que a at ajudou-a conscientizar seus familiares da necessidade do tratamento orgânico e psíquico, entendendo sua necessidade de atendimento.

Um outro aspecto citado pelos colaboradores foi a percepção da at como alguém que acolhe e os escuta, ajuda-os a se conscientizarem da necessidade de cuidarem de si 
mesmos. A escuta é aqui considerada como a atenção aos aspectos verbais e não-verbais do cliente ampliando, assim, a compreensão do que ele quis expressar, bem como de suas dificuldades e necessidades, o que possibilitou a intervenção do at.

Essa intervenção ocorre sempre tendo em mente o projeto terapêutico, traçado para o acompanhado pela equipe terapêutica, e, também, os significados, implicações e conexões desse material para ele mesmo e para sua vida.

Ressaltamos que, ao longo dos atendimentos de Ari, Elaine, Vânia, Daniela, Edivânia e Sandra, a at acolheu as angústias deles e, assim, pôde ressignificá-las. Várias vezes isso foi feito através da escuta atenta, outras vezes pelo espelhamento, quando a acompanhante, com suas ações, mostrava outros modelos de agir no mundo, mais sadios de realização ajudando-os, inclusive, a tomarem algumas decisões que, sozinhos, não fariam. Percebemos, ainda, que essa atuação possibilitou a intermediação e circulação nos vários espaços que o paciente ocupava favorecendo uma flexibilização de seus movimentos.

\section{5 categoria: Enfrentamento}

Percebemos que a angústia e a solidão atuam neste momento como um estímulo para lutar, buscando caminhos mais satisfatórios para a vida de Ari, que fala da angústia de se deparar com o vazio da vida inautêntica que se desvela quando atribui ao outro - os familiares - a sua solidão, favorecendo um isolamento sem, com isso, comprometer-se em estabelecer, ele próprio, relações mais satisfatórias com seus familiares.

(...) mas eu luto contra esses momentos de desânimo, de angústia ou é parte da vida que eu levo nesta solidão (...) por que eu sinto uma vida muito desprezada por parte dos familiares - filhas - (...) por parte dos familiares sinto desprezado (...) Ari.

Há que se pensar que nós, seres humanos, vivenciamos um isolamento que é uma lacuna, que não é suprido pelo outro, e somente pode ser diminuído através do 
autoconhecimento e da conscientização da responsabilidade de cada um com a sua vida e as suas escolhas.

Quando temos conhecimento da nossa condição de seres de falta e nos responsabilizamos por nossas escolhas, possibilitamos assumir nossa carência e orfandade e nos organizamos de outras maneiras mais satisfatórias. Podemos ver nas palavras de Ari, que ao mesmo tempo em que mostra o desânimo e a angústia, afirmando que não é dono de sua vida, ele explicita uma força que o impulsiona à realização de seus projetos.

\section{$6^{\circ}$ Categoria: Projetos}

Ari se apresenta como ser de necessidades e, enquanto tal, coloca-se como ser-nomundo, ser de falta, que se lança em busca da satisfação e realização de seus projetos. Só buscamos a realização de alguma coisa porque ela nos falta e os nossos desejos nos lançam ao mundo para nutrir-nos do que estamos carentes; quando isso acontece, estabelecemos uma relação autêntica com o mundo ao redor, seja com os entes ou outros seres, como podemos apreender em sua fala.

Eu ainda estou vivendo sozinho, mas (...) (eu vou conseguir constituir nova família) (...), pretendo realizar meus sonhos (...), principalmente o problema da casa que eu estou (...) (está) correndo tudo bem, da maneira que eu espero, praticamente eu penso em ter uma nova união, apesar da minha idade, mais uns anos de felicidade é o que eu espero (...) Ari.

Sandra explicita, em sua fala, projetos e demonstra saber o que precisa fazer para se relacionar bem com sua mãe, inclusive com idéia clara do que a mãe gosta e fazendo comparação com seu comportamento atual.

(...) é só colocar o dente, ficar mais bonitinha, sem responder pra mãe, sem responder pra minha mãe nunca mais, eu to xingando palavrão, não pode falar palavrão perto dela, ela não gosta (...) Sandra. 
O ser humano é projeto, opção que vai fazendo ao longo de sua vida, por si só as coisas, acontecimentos não têm sentido, quem confere sentido a eles é o próprio indivíduo a partir de seus valores, conceitos e pré-conceitos.

\section{$7^{\text {a }}$ Categoria: Percepção do outro}

Com Vânia, a at entrou na co-participação do tratamento com o objetivo inicial de sensibilizar sua família e ela mesma da necessidade de tratamento.

Por que parece que você estava insistindo comigo, (...) porque parece que tava insistindo né (...) você forçou um pouquinho de eu ir (...) eu não queria ir (para a internação) (...) eu fiquei com raiva de você (...) eu não queria mais te ver (...) porque você forçou um pouquinho a barra, você (...) acho que foi você que fez meus irmãos me levarem não foi? (...) eu achei que você forçou um pouquinho assim eles (...) Vânia.

No relato de Vânia, aparece a incapacidade de se cuidar pela negação de sua patologia, dor e limitações como andar e deitar-se devido ao seu estado orgânico demonstrado pela indiferença, desinteresse e apatia. Ela apresentou também grande sensibilidade quando relatou saber de tudo que se passou ao redor dela, inclusive todas as negociações do at com os familiares e desses com a equipe de saúde do PSF.

Ressaltamos, aqui, que é comum essa hostilidade do enfermo mental com a equipe que o trata e da negação do tratamento por ele. Para Mauer e Resnizky (1987), esta atitude é devido principalmente à dificuldade que essas pessoas têm em lidar com os sentimentos de carência. Essa carência favorece que elas se distanciem da realidade negando suas necessidades e/ou rompendo relacionamento com as pessoas ao seu redor, desconectando, assim, do seu ambiente e da realidade que lhe é dolorosa, mas por outro lado vivendo de maneira isolada. 


\section{$8^{a}$ categoria: Percepção do trabalho do Acompanhante Terapêutico}

Vânia relata, em seu discurso, a recusa em falar de si, mostrar-se ao outro e aceitar a ajuda que estava sendo oferecida. Demonstra a dificuldade que muitos indivíduos, em sofrimento psíquico, enfrentam de fazer trocas com o outro, mesmo que seja para pedir ou aceitar ajuda e atendimento favorecendo, assim, na adesão ao tratamento.

(...) era bom quando você vinha aqui (...) eu gostava, eu gostei (...) só que eu não queria me abrir, não é que eu queria me abrir, eu não tinha nada prá esconder, prá esconder, eu só não queria falar, (...) Vânia.

O trabalho em acompanhamento terapêutico vai além do ouvir. Busca reconectar o indivíduo consigo mesmo e com o ambiente ao seu redor, para que o indivíduo estabeleçase no mundo como ser-com-o-outro possibilitando diálogo, interação com a família, com a equipe terapêutica o que favorece transitar pelo social, assim como criar novas situações que permitam o contato com a realidade, auxiliando a (re)conexão do paciente com o outro e com o mundo, buscando criar e ampliar "redes" de relacionamento. Para isso, utilizam-se recursos teóricos e práticos do profissional e outros que a própria cidade oferece.

Os atendimentos podem ser realizados fora da clínica, como na residência do paciente ou em qualquer lugar pertinente. Essa clínica objetiva tratar o indivíduo dando sentido às suas vivências e (re)construindo sua história pessoal, como podemos ver nas palavras de Caiaffa: “(...) queremos entrar: nós, a rua, novas possibilidades de vida para alguém que estando desorganizado, indiscriminado para responder a essa chamada, reage com pavor ao que pretende entrar (...)" (CAIAFFA, 1991, p.95).

Nas visitas, nos encontros entre acompanhado e acompanhante, vão tecendo-se possibilidades para o indivíduo que estava fechado em seu mundo. O acompanhante terapêutico não utiliza apenas da sua fala para ajudar o indivíduo e, sim, de todos os recursos disponíveis que a comunidade oferece tais como: relações, espaço social, medicação. 
O acompanhante está in loco e, nessa perspectiva, com todas as possibilidades que permitirão ajudar o enfermo mental em seus estranhamentos, dificuldade, apavoramento, desânimo e imobilidade que as diversas patologias submetem, em diferentes graus, a pessoa doente.

Esse profissional busca, através de outros espaços que não a clínica, o movimento, o ir e vir, a circulação favorecendo uma outra ordem que traz outras e novas “(re)significações” para sua história, como podemos ver a seguir:

O acompanhante terapêutico, nesse trajeto, é um terapeuta que não se limita a trabalhar dentro de um consultório (...). Trabalha onde o paciente está, é um terapeuta que vai ao paciente e esse andar é corpo a corpo (...) O andar é simbolicamente, é colocar em possibilidades, é uma maneira simbólica de chegar a algum lugar (MARQUES, 1991, p. 103).

Vânia retrata a dificuldade, que muitas vezes um at e/ou a equipe de saúde enfrentam para conscientizar o enfermo mental e sua família sobre a gravidade e necessidades que esse indivíduo tem de requerer assistência especializada e contínua.

(...) você cooperou né, porque você veio aqui, o Valdo fez umas perguntas pra você né , eu sei que você falou umas coisas pra ele (...) e eu não queria ir, e você e ele conversaram, né (...) eu não sei se foi pra me levar (...) a Marciana ela que falou com meus irmãos, você não falou com eles? (...) ajudou falando com meus irmãos (...) e, eu não sei se meu irmão, alguém orientou meu irmão quanto as minhas pernas (erisipela) ou como ele ficou sabendo que podia (...) que tava correndo risco (...) eu não sei como ele ficou sabendo disso, foi você que falou pra ele?(...) Vânia.

Percebemos que, apesar da confusão de Vânia, ela sabe que os cuidados que recebeu eram necessários para ela, apesar das dificuldades em aceitar ajuda médica. $\mathrm{O}$ at foi fundamental como agente socializador entre ela e seus familiares e também entre a família e o PSF que encaminharia para os tratamentos necessários, no caso a internação para tratamento clínico e posterior internação psiquiátrica até seu restabelecimento.

Vale dizer que não somos favoráveis à internação, quando desnecessária ou apenas como medida de punição, mas esta colaboradora corria risco de uma trombose nos 
membros inferiores já que estava com uma erisipela bolhosa e, uma anemia séria, devido a sangramentos vaginais ininterruptos que não estavam sendo tratados.

Uma das funções do at é de emprestar o ego, fazendo pelo cliente ou ajudando-o nas tarefas que não consegue realizar por si só. Isso significa que ele pode precisar fazer por ele como, por exemplo, com Vânia, que não aceitava a intervenção médica e corria grave risco de vida. Essa ação terapêutica ajudou Vânia a se conscientizar e a se submeter ao tratamento psiquiátrico depois de ter sido tratada de sua debilidade orgânica.

Após o exposto discorreremos sobre a percepção que os familiares de nossos colaboradores têm do acompanhamento terapêutico.

\subsection{2 - Os familiares do portador de sofrimento psíquico}

A fenomenologia existencial permite-nos vislumbrar outras possibilidades, a partir da realidade do que já está dado. Nesse sentido a possibilidade é sempre "maior" do que a realidade que se apresenta. "Mais elevada do que a realidade está a possibilidade. A compreensão da fenomenologia depende unicamente de se apreendê-la como possibilidade" (HEIDEGGER, 1988, p. 69-70).

Com intuito de apreender a percepção que os familiares de indivíduos portadores de enfermidade psíquica têm do AT, buscaremos em seus relatos e nos autores que ancoram este estudo a compreensão dessa realidade.

Foram desveladas as categorias: percepção de paciente pelo familiar, história de vida, os tratamentos, percepção do tratamento. 


\section{$1^{\text {a }}$ categoria: Percepção do paciente pelo familiar}

$\mathrm{Na}$ visão do familiar Aleandro, que é irmão e não convive com Ari, fica explícita uma crítica ao seu modo de ser e de viver disruptivo, denunciando um distanciamento afetivo. Esse distanciamento pode ser conseqüência do comportamento do colaborador, que teve uma "vida desregrada", com a boemia, a necessidade de conquistar várias mulheres, o uso de drogas. O distanciamento de Ari e seu irmão e dos outros familiares dele, inclusive suas filhas, é percebido pela dificuldade de encontro e relacionamento autêntico evidenciado pela diferença entre colaborador e Aleandro, os outros irmãos e suas filhas, nos projetos de vida, nas crenças, nos valores e nas escolhas pessoais como foi explicitado no relato abaixo.

(...) Ele bebia muito (...) todos os dias quatro a cinco cervejas (...) Quando ele ficou aqui em casa (morou com Aleandro alguns meses quando estava fazendo tratamento no $\mathrm{HD}^{25}$ ), ele bebia. Ele fazia tratamento no HD e chegava em casa e bebia (...) Ele é muito manhoso (...) teve sempre tudo na mão. Eu tenho uma irmã que ajudava muito ele, mesmo depois de casado (...) Aleandro (irmão de Ari).

Essa categorização de indivíduo boêmio, com uma vida desregrada, leva-nos a refletir que o familiar discrimina Ari pela dificuldade de compreendê-lo. Essa categorização negativa distancia o irmão de Ari.

Margarida descreve Sandra, sua filha, pelos momentos vividos de animação, alegria, bem-estar ou de desânimo, ansiedade, isolamento, silêncio, ou seja, com os altos e baixos próprios da existência humana. Mas, percebemos, em sua fala, a ênfase na improdutividade de Sandra, enfatizando a desobrigação dela com as tarefas domésticas, desvalorizando qualquer outro esforço que faça como sua participação nos grupo de artesanato, no grupo de descontração e nos bailes que ocorrem quatro vezes por semana no bairro onde mora.

\footnotetext{
${ }^{25}$ Hospital-dia da Faculdade de Medicina de Ribeirão Preto - USP.
} 
(...) tem dia que ela (Sandra) tá meio agitada tem dia que ela tá bem, tem dia que ela fala muita coisa, tem dia que ela num fala nada, dia que ela fica alongada o dia inteiro no quarto (...) ela tá meio é embirrada, ela não quer saber de trabalhar não (...) quer ficar à toa. Num que lavar panela, num que arrumar a cozinha, hoje eu arrumei toda a cozinha, ela acordou era nove e meia (...) Margarida (mãe de Sandra).

Margarida, no seu discurso, tem uma crítica de que Sandra não gosta do que ela se interessa como se o correto fosse que a filha tivesse as mesmas preferências que ela.

(...) ela não é uma pessoa que gosta de tá chique (...), ela não gosta de um relógio, ela não gosta de um anel, ela não gosta de um (...), de um colar, ela não gosta de um brinco, ela não gosta de nada disso. Ela tem as coisinhas dela que as meninas, as colegas dela tudo dá, lá no bailinho eles dão as coisas lá pra ela (...), só que ela não usa nada disso. Se ela usa um colarzinho ela tira, se ela vai com um relógio ela tira o relógio e põe na minha bolsa, ela não gosta de anel, ela não gosta de nada, de nada, nada, nada (...) Margarida (mãe de Sandra).

Percebemos, na fala de Margarida, a valorização da improdutividade da filha baseada na dependência de Sandra para cuidar de sua alimentação ou fazer as tarefas domésticas da casa participando, com ela, da sua manutenção.

(...) ela fica o dia inteiro mole assim, o dia inteiro, nem arrumar mais a cozinha ela não quer. Para tomar um leite eu tenho que esquentar porque ela não quer, e ela fazia tudo sozinha, eu não me preocupava ela esquentava comida, ela fazia, fervia o leite dela, esquentava o leite dela, tomava, ela sabia o horário direitinho, agora virou essa coisa aí, nem toma sozinha o café, nem esquenta (...) Margarida (mãe de Sandra).

Ao longo dos atendimentos e no discurso de Margarida ficou evidente o distanciamento dela para com a filha, denunciando a dificuldade de relacionamento interpessoal entre ambas, que pode ser compreendido pela realidade de ter uma filha com limitações e necessidades especiais, inerentes a uma pessoa portadora de síndrome de Down.

Um outro aspecto é relatado por Vanildo que encoraja e espera que sua irmã Vânia busque por si mesmo, cuidar sozinha do seu tratamento, não considerando a realidade vivenciada por ela em sua vida com a limitação da sua vontade e de sua capacidade.

(...) Ela toma remédio, hoje (...) acho que ela tem uma melhora quando ela tem uma disposição de buscar por ela, uma melhora em prol lado dela, então eu acho que esse lado ajuda ela, mas normalmente quando ela fica na dependência, às vezes assim, do remédio ela não, não, não noto melhora nela (...) Vanildo (irmão de Vânia).

Notamos, pelas falas dos familiares-colaboradores, um movimento de olhar para o outro com a expectativa de que esse outro fosse diferente em sua forma de existir, com 
comportamentos, atitudes e reações mais adaptadas ao ambiente social e aos desejos e valores desses familiares. Todos os entrevistados ressaltaram falhas físicas ou emocionais sem considerar e, até mesmo, perceber o esforço e a mudança, mesmo que pequena, do seu familiar enfermo mental.

Denunciaram, ainda, a impossibilidade de ver o enfermo mental como ele é, pelo contrário, o enxergam através de si, por comparação com eles mesmos e/ou com a imagem que gostariam que esse familiar tivesse.

Nesse sentido é preciso refletir que o indivíduo só existe em um mundo já dado e, portanto, esse mundo, com todos os equipamentos sociais de que dispõe, favorece o desenvolvimento do ser facilitando sua socialização e desenvolvimento de habilidades. O indivíduo, portanto, não está pronto, mas pode, a todo o momento, ser instigado a responder a esse social de maneiras diversas e estando nesse social ser estimulado a responder dentro do esperado por esse ambiente.

Percebemos que as expectativas dos familiares-colaboradores são diferentes das dos clientes-colaboradores, denunciando um distancimento entre eles como pudemos perceber com Sandra, Elaine e Vânia, nos discursos de Da. Margarida, Vanildo e nas falas de Da. Társia $^{26}$. Nossa percepção é que eles eram tratados de maneira distante, sem muito contato com os familiares.

\section{$2^{\text {a }}$ categoria: História de vida}

Nessa categoria, Aleandro relata a trajetória da vida de seu irmão, em uma seqüência temporal. Nesse relato percebemos uma ênfase para os aspectos negativos dessa

\footnotetext{
${ }^{26} \mathrm{O}$ familiar citado não consentiu em dar a entrevista, mas apresentou, durante os acompanhamentos de sua filha, Elaine, uma atenção solícita, valorizando a melhora de sua filha, se tornando indisponível quando a at a procurou pedindo outro tipo de ajuda, do que a ajuda oferecida - espaço em sua casa para os acompanhamentos Elaine -at.
} 
experiência. Essa crítica dificulta o diálogo entre os familiares e o colaborador-cliente, distanciando-os.

A vida dele (...) ele começou, teve uma mulher (Pedrina), depois outra (Nilza) (...) duas filhas. Ele é trabalhador, mas boêmio. Depois que a mulher ficou doente (...) ele ficou (assim) e logo depois ele arrumou uma mulher (...) A Nilza teve um filho e, faz uns três meses que ele não manda pensão. (...) Ele separou da mulher (Nilza) eles brigavam muito (...) ele já foi usuário de droga também. Ele não se conformava em ficar sem beber. Ele foi mulherengo, teve uma vida sempre desregrada. (...) Ele bebia muito (...) depois ele ficou doente. (...) Ele gostava muito da mulher (Nilza), e (ele) adoeceu depois da separação (...) eles bebiam muito e brigavam (...) Aleandro (irmão de Ari).

Margarida retrata a APAE como escola e lugar de tratamento referindo-se ao tempo que Sandra freqüentou essa instituição, como o período mais produtivo de sua vida, inclusive, sendo modelo de comparação até hoje como limiar de produtividade e comportamentos esperados pela mãe. Porém, ao mesmo tempo em que Margarida remete a APAE como positivo pelos aprendizados e desenvolvimento de habilidades que Sandra teve naquele ambiente, não fez nenhum esforço ou movimento para mantê-la freqüentando aquele espaço educacional.

(...) ela tinha uns nove anos, na idade dela mesma tinha uns nove anos. (...) Ela mesma que quis sair, ela não quis continuar, ela falou que não queria ficar lá, que não (...) queria ficar mais (...) Margarida (mãe de Sandra).

Ressaltamos que, esboçando uma crítica à maneira como Ari e Sandra se comportam, Aleandro e Margarida, respectivamente, expressam não compreendê-los.

\section{$3^{\text {a }}$ categoria: Os tratamentos}

Aleandro referencia os vários lugares onde seu irmão fez tratamento, ressaltando o lado agressivo dele, nem levando em conta os diferentes tratamentos oferecidos pelo CAPS e pelo PSF e demonstrando desconhecer o projeto terapêutico de Ari. 
(...) Ele fez tratamento no $H D$, no $H C^{27}$, no $S$. Vicente de Paula ${ }^{28}$. (...) ele teve no NAPS $S^{29}$ também e brigou lá com o Dr. Aroldo (psiquiatra), agora ele tem consulta com o Dr. Laércio (psiquiatra) (...) ele fez tratamento no HC, no S. Vicente de Paula, no NAPS e no posto da Vila Tibério ele trata até hoje (...) Aleandro (irmão de Ari).

No relato acima ficou explícito que o colaborador passou por vários serviços de saúde mental, o que nos leva a pensar na dificuldade em aderir ao tratamento e permanecer em um serviço.

Nas palavras de Aleandro, observamos que Ari teve história de várias internações psiquiátricas, o que nos leva a refletir sobre a dificuldade de inserção na comunidade e nos serviços de saúde Mental, como o NAPS e o CAPS $^{30}$. Ari começou a freqüentar o CAPS, mas abandonou o tratamento, ficando sem acompanhamento psiquiátrico, seguindo orientação medicamentosa no PSF - Núcleo Vila Tibério, apesar do médico que o atende neste serviço encaminhá-lo, reiteradas vezes, inclusive, enfatizando a importância dele fazer uma reavaliação com o médico psiquiatra. Além de se negar a ir ao CAPS, ele tinha dificuldades para seguir a orientação medicamentosa prescrita.

Percebemos a dificuldade de Ari em se vincular ao serviço, e do serviço favorecer a inclusão nos dispositivos que a comunidade oferece, como cursos, encontros, atendimentos, lugares que possibilitem a troca, ou seja, aumente sua capacidade de contratualidade.

Apesar de ter aprendido trabalhos manuais, como tear de pregos e construção de objetos com palitos de sorvete, durante as internações pelas quais passou, Ari, inicialmente, não fazia uso dessas habilidades para ocupar seu tempo, construir trabalhos artísticos e, também, como possível complementação de sua renda, o que favoreceria seu restabelecimento, a interação com outras pessoas e o aumento da contratualidade com o ambiente do qual fazia parte. Necessário dizer que, a at ajudou Ari a resgatar sua auto-estima

\footnotetext{
${ }^{27}$ Hospital das Clínicas de Ribeirão Preto.

${ }^{28}$ Sanatório Espírita São Vicente de Paulo.

${ }^{29}$ Núcleo de Atenção Psicossocial - Ribeirão Preto.

${ }^{30}$ Centro de Atenção Psicossocial - Ribeirão Preto.
} 
a partir da construção de trabalhos em madeira como bancos e brinquedos infantis, toalhas feitas no tear e, portanto, redescobrindo suas habilidades e capacidades.

Um outro aspecto importante é trazido por Vanildo, é que muitos enfermos psíquicos exigem disponibilidade interna, paciência do outro - familiar ou profissional de saúde - para cuidar dele. Em momentos como os relatados anteriormente, foi preciso lançar mão da violência de levar essa colaboradora contra a sua vontade, fazendo uso de aparato policial, para atendimento e medicação e, quando necessário, para a internação.

(...) quando ela foi levada assim amarrada, forçada para o hospital foi, foi uma coisa boa pra ela aquilo, se não tivesse feito, se ela não tivesse sido medicada, não tivesse sido tratada podia ter complicado a vida dela. E (...) a partir disso ela ficou internada (...) né (...) no Santa Tereza e (...) e depois de um certo tempo ela voltou, ela continuou a querer fazer esse tratamento (...) Vanildo (irmão de Vânia).

Vanildo, em seu discurso, traz a recusa que alguns pacientes apresentam em tomar a medicação já que essa, muitas vezes, os inibem em suas vontades e desejos, deixando-os mais contidos, o que para muitos, é percebido como limitante. Vale lembrar ainda dos efeitos colaterais que são muitos. Os mais freqüentes são: secura na boca, constipação intestinal, sonolência, rigidez muscular, impotência sexual.

Pensar essa recusa do cliente, o abandono do tratamento psiquiátrico e até mesmo a dificuldade do portador de enfermidade psíquica em seguir nos tratamentos propostos - não só o atendimento medicamentoso - é tarefa árdua e constante de todos os envolvidos com esses tratamentos. O intuito primordial é diminuir as perdas e os obstáculos favorecendo, assim, condições de vida mais saudáveis.

Vale dizer que, pela experiência profissional $^{31}$ como psicóloga e at, pessoas portadoras de algum transtorno psíquico precisam fazer uso de medicação para reprimir sintomas psicóticos e não o fazem, já que além de não sentirem os efeitos colaterais eles costumam sentir-se onipotentes, apresentando quadro de alucinação, expressando-se capazes

\footnotetext{
${ }^{31}$ Aqui está sendo relatado a experiência de uma das pesquisadoras.
} 
de qualquer conquista, vivenciando-a, mesmo que imaginariamente, com a realização completa de seus desejos e fantasias, sem lidar com a frustração, angústia, limites que a realidade impõe naturalmente.

De acordo com Kaplan e Sadock (1999), a falta de adesão ao tratamento é uma questão séria que responde a perdas econômicas importantes e morbidade clínica significativas, além da diminuição da produtividade social. Como solução propõem algumas estratégias como o envolvimento persistente de pessoas interessadas que podem ser: o médico, capaz de ajudar a identificar as barreiras à adesão e adaptação das recomendações terapêuticas à vida e rotina do enfermo psíquico; os membros da família ou companheiros da doença que podem atuar apoiando e encorajando o portador de sofrimento psíquico a buscar estratégias para solucionar problemas comuns.

Pelos relatos, aventamos que a inserção e a reabilitação do portador de sofrimento mental, após a alta hospitalar, requerem alguns cuidados ou um intermediador que faça a inserção desse indivíduo na comunidade e nos serviços de atendimento. O PSF mostrou ser um local de atendimento que visa à prevenção primária e secundária eficiente, mas carece, ainda, de meios ou pessoal especializado habilitado para essa demanda, o que pode ser favorecido pelo acompanhante terapêutico que cumpre esse papel fazendo a ponte entre o enfermo e o outro - familiar, serviço de saúde, espaço social.

$\mathrm{O}$ at, em algumas situações com seu cliente, cumpre a função de estar junto dele ajudando-o a se compreender através de um diálogo que permite clarear seu estado emocional, favorecendo que este indivíduo ressignifique suas atitudes e possa transformar sua existência. Diversas vezes isso ocorre quando o indivíduo precisa escolher entre várias possibilidades e, sabendo ou não das conseqüências, não consegue decidir ou executá-las sozinho como percebido com Ari, Vânia, Edivânia, Daniela, Sandra, Elaine. 


\section{$4^{\text {a }}$ categoria: Percepção do tratamento}

\section{Percebendo a mudança}

Após seis meses de AT, Aleandro, apesar do distanciamento, percebe a mudança de Ari inclusive enumerando seus ganhos. Como valoriza a melhora do irmão, participa estimulando o trabalho dele, arrumando ferramentas para que crie suas peças em madeira.

(...) Agora com o seu trabalho, com o tratamento ele foi melhorando (...) hoje com o seu acompanhamento ele está uns $90 \%$, não vou por $100 \%$ porque às vezes ele não está bem (...), mas ele está bem, fazendo sua comida, cuidando de suas coisas e agora está cuidando da neta (...) Ele tá bom, tá ótimo (...) eu arrumei umas ferramentas para ele e ele tava fazendo uns brinquedinhos, porta vaso (...) Aleandro (irmão de Ari).

O acompanhante terapêutico tem como função, de acordo com Barreto (1998), Mauer e Resnizky (1987), estar junto com o paciente, buscando resgatá-lo do seu mundo particular, o que pressupõe ser capaz de conter, acolher, acompanhar e refletir com ele sobre suas ações.

\section{Percebendo a especificidade do tratamento em saúde mental}

Josué, marido de Daniela explicita a especificidade do tratamento em saúde mental em que há melhora, ganhos, retrocessos, recaídas, ao mesmo tempo em que o indivíduo melhora, não perdura e retrocede a comportamentos desajustados que tinha antes do tratamento.

(...) Bom é o jeito dela né (...) no dia-a-dia ela muda (...) por exemplo o tratamento está sendo feito de uma forma né (...) ela (...) ta agradando ela , ela tá se sentindo bem com o tratamento, então parece que ela vai (...) que tá melhorando e e aí (...) de uma hora para outra aquilo ali desaparece, aquela melhora desaparece (...) Josué (marido de Daniela). 
Esse colaborador percebe que houveram ganhos com o AT, e, mesmo quando tem a impressão que o tratamento não está sendo útil, consegue vislumbrar que há melhora em sua esposa.

(...) parece que o tratamento não tá servindo de nada, mas na verdade tá sim, é claro, nós sabemos disso, mas aparentemente (...) parece que está paralisado (...) Josué (marido de Daniela).

Quando Josué fala da oscilação de humor retrata, com propriedade, a angústia do familiar que convive com enfermo mental, no dia-a-dia presenciando a oscilação de humor, a frustração da recaída ou até mesmo da instabilidade emocional comum em alguns quadros de transtorno mental.

(...) ao mesmo tempo que parece que ela tá bem não fica tão bem assim, de uma hora para outra né (...) (ocorre) oscilação de humor mesmo, porque de uma hora para outra ela já muda (...) Josué (marido de Daniela).

\section{Participando da melhora do paciente}

No discurso de Vagner, marido de Edivânia, aparece a percepção da melhora de sua esposa, não somente nos sintomas que a levaram para o atendimento com o at - ansiedade excessiva - mas também em outros aspectos da vida dela e da vida conjugal.

(...) ela melhorou pra mim em todos os aspectos (...) de pouquinho em pouquinho ela foi melhorando (...) Vagner (marido de Edivânia).

Esse familiar valoriza a abertura que o atendimento com at possibilitou, para a relação deles, sendo que ele também se colocou como agente de mudança, disposto a cuidar da esposa incentivando o tratamento dela e a relação conjugal. Nesse sentido, percebemos que o marido propiciou um aumento da convivência entre eles o que contribuiu para um relacionamento mais autêntico e satisfatório para ambos.

(...) a gente foi dando uns espaços para ir acertando o que estava errado e (...) sempre estava do lado dela conversando, acompanhando, ela queria sair, ela chamava (o marido) para sair - "ah vamo dá uma volta, preciso dar uma volta" -, pegava ia dá uma volta (...), ia aqui na Avenida do Café dar 
uma volta (...) então foi trocando isso ai por a gente caminhando à noite, conversando, acertando (se entendendo) (...) Vagner (marido de Edivânia).

\section{Demonstrando a dificuldade em cuidar do outro}

Vanildo percebe que Vânia teve ganhos com o AT, mas ressalta ser ela própria capaz de decidir sobre a continuidade do tratamento, inclusive com relação à ingestão da medicação.

(...) Eu acho que na parte psicológica ajudar (o at contribui para a conscientização de Vânia em tratarse) você precisa se cuidar eu acho que você ajudou ela bastante nesse sentido de despertar nela esse interesse de se cuidar, isso é importante, chegou o ponto que ela nem queria se cuidar. Se cortasse a perna dela (...) deixa cortar era isso que ela falava (...) não comia, tava fazendo as necessidades no quarto, no corredor e não tava nem aí porque aquilo que tava agindo na cabeça dela, tava fazendo tudo isso (...) Vanildo (irmão de Vânia).

Percebemos que Vanildo e toda a família deixam a cargo de Vânia a responsabilidade de se tratar, deixando a colaboradora como responsável pelo seu tratamento.

Observamos que, tanto ele quanto sua família, não conseguem estabelecer com Vânia uma relação cuidadosa, comprometendo-se com e por ela, que explicitou sua incapacidade em se autocuidar e decidir sozinha sobre a necessidade de um tratamento. Ressaltamos que, na história de vida de Vânia, foi comum o abandono do tratamento psiquiátrico com reinternações, sendo que ela tem relato de adoecimento por volta de 18 anos.

Posterior à internação foi proposto retomar os acompanhamentos, com o objetivo de inseri-la na comunidade, ampliando seus contatos sociais. A família se ausentou e não se responsabilizou pelo tratamento, deixando a cargo de Vânia a decisão pela continuidade deste, o que não ocorreu.

Vanildo mostrou ser indiferente às necessidades de sua irmã, deixando a ela o direito e a responsabilidade de cuidar de si e decidir por seu tratamento, sem se dar conta das dificuldades ou incapacidades de Vânia em fazer isso sozinha. 


\section{Apresentando a dificuldade em aceitar a melhora do outro}

Margarida, destoando dos discursos de outros familiares colaboradores desta pesquisa, não percebe nenhuma mudança positiva em sua filha inclusive desvalorizando os ganhos em socialização que Sandra apresentou.

(...) noto pouca diferença, pouca diferença. Ela é (...) pus bailim (baile que acontece em um salão, no bairro em que mora) dela que ela gosta de ir isso ai eu notei uma diferença porque antes eu não levava ela, ela ficava aqui só que depois eu levei ela uma vez duas pronto agora ela sai sozinha e vai, ela gosta de dançar de, de ,de conversar (...) Margarida (mãe de Sandra).

Percebemos com a fala desse familiar colaborador que a melhora ou qualquer mudança positiva ou negativa em Sandra é associada ao uso da medicação, inclusive demonstrando a expectativa de que sua filha não mudasse, mantendo-se como era quando tinha 20 anos de idade - mais dócil e obediente.

Margarida não valoriza a mudança de Sandra, porque isso exige dela modificação nos padrões de convivência familiar. Um outro aspecto que precisamos considerar é que ver o crescimento do outro e dele participar, traz, para algumas pessoas, a angústia de não ter o outro como era - limitado mas dependente.

\subsection{3 - As agentes comunitárias}

Neste momento buscamos compreender a percepção e os sentidos que as agentes comunitárias atribuem ao Acompanhamento Terapêutico. Faremos isso através dos fragmentos dos relatos dessas profissionais.

Após a leitura das entrevistas, apreendemos oito categorias, a saber: percepção do trabalho com o indivíduo portador de sofrimento psíquico; expectativas do trabalho do acompanhante terapêutico; percepção do trabalho do Acompanhamento Terapêutico; a 
percepção do tempo no tratamento; percebendo a solidão do outro; vínculo profissionalpaciente; insegurança; Importância do trabalho do acompanhante terapêutico, que passaremos a descrever no próximo tópico.

\subsection{3 - A compreensão dos agentes comunitários}

\section{$1^{\text {a }}$ Categoria: Percepção do trabalho com o indivíduo portador de sofrimento psíquico}

O PSF, embora rotulado como programa, caracteriza-se como uma estratégia de saúde dentro do SUS para assistência primária e secundária. Tem-se mostrado como instrumento fundamental para a Reforma Psiquiátrica.

Dessa maneira, para atuar dentro das propostas do novo paradigma de saúde, há a necessidade de uma abordagem holística dos problemas dos pacientes, combinando com o propósito do PSF, de olhar o enfermo no contexto familiar e social em que vive, uma vez que elege a família e seu espaço social como núcleo básico de atuação no atendimento à saúde, humanizando-a através do estabelecimento de vínculo entre os profissionais e a população, intervindo nos fatores de risco e melhorando a qualidade de vida. Assim, o PSF requer das equipes o desenvolvimento de atitude solidária e afetiva, diante da realidade da população e de seu sofrimento, entendendo que os problemas nem sempre são de origem biológica e que podem ter outras dimensões tais como epidemiológica, cultural, social e principalmente emocional (ROSA, 2002).

Percebemos que os pacientes que foram atendidos pela at denunciam um adoecimento que, muitas vezes, foi agudizado por dificuldades emocionais e sociais. Todos eles tinham uma patologia orgânica diagnosticada e com tratamento em andamento nos serviços especializados, inicialmente no NAPS e posteriormente no CAPS. Observamos que a 
vaga e o oferecimento do serviço não garantiram a continuidade do tratamento pelo usuárioenfermo-psíquico, já que, por diversas razões, eles boicotaram e abandonaram esse atendimento como ocorreu com Ari, Vânia, Daniela e Elaine.

Gabriela retrata, em sua fala, a especificidade do atendimento em saúde mental que ocorre, muitas vezes, de não ser bem recebida ou que a presença do agente de saúde não é bem-vinda naquele momento, seja pela dificuldade em estabelecer ou manter vínculos, seja pelo distanciamento momentâneo do enfermo mental de sua realidade ou, ainda, pela necessidade do profissional da saúde sensibilizar o morador e seus familiares do trabalho, dos benefícios da visita e dos serviços que o PSF oferece.

(...) eu acho que dessa forma do jeito que você chega, do jeito que você é recebida, desde o primeiro momento, então eu acho que a partir daí até nas próximas visitas você vai ver como vai ser, por que um dia ele vai te receber bem, um dia o outro não recebe, um dia a família quer que você não bata no portão (...) então eu acho que isso (...) eu acho que isso vai (...) assim evolui, às vezes (...) Gabriela.

Ao contrário da desinstitucionalização psiquiátrica ocorrida na Itália, houve uma ampla mudança na saúde mental envolvendo todos os atores ligados à saúde com treinamento. A Reforma Psiquiátrica ocorreu de maneira gradativa no interior da própria instituição psiquiátrica transformando a organização, as relações e os papéis que cada um desempenhava ali. Os profissionais passaram a ser co-agentes nesse novo modelo.

Aqui no Brasil vem ocorrendo um processo de mudança, em grande parte, de cima para baixo, onde a diminuição do número de vagas para a internação psiquiátrica é realizada sem a criação concomitante de serviços substitutivos que cobrissem as necessidades dos enfermos mentais, ocasionando aumento de recidivas e re-internações (ROTELLI et al. 2001).

Observamos, no PSF, obstáculos em lidar com o sofrimento psíquico, percebido na dificuldade em assisti-lo em suas necessidades o que, muitas vezes, distancia o enfermo mental dos serviços de assistência à saúde. Uma assistência humanizada favorece compreender o indivíduo além de sua doença ou sintomas que apresenta, propiciando a 
promoção da saúde mental não só do enfermo mental, mas de seus familiares e de toda a comunidade.

\section{$2^{\text {a }}$ Categoria: Expectativas do trabalho do acompanhante terapêutico}

Percebemos que a at entrou no PSF para realizar o AT, quando outros recursos já haviam sido tentados sem sucesso, deixando a equipe e, principalmente, as agentes comunitárias sem saber o que fazer ou a quem mais recorrer.

Um exemplo disso ocorreu com Ari, morador do bairro na área de abrangência da Agente Comunitária de Saúde (ACS) Érica. O médico de Saúde da Família, a enfermagem e o agente comunitário eram suas referências de atenção profissional à saúde. Ari, também, estava cadastrado no Núcleo de Atenção Psicossocial - NAPS, porém tinha abandonado o tratamento e se recusava a ir e seguir a prescrição do psiquiatra e a do médico do PSF, fazendo uso da medicação - Triptanol e Diazepan — de maneira abusiva e indiscriminadamente, ora tomando quantidade de medicação que o dopava e o deixava dormindo o dia todo, ora não ingerindo nenhuma dose. Resistia ao tratamento oferecido, mas exigia atenção redobrada da agente comunitária que o atendia.

Nesse sentido, Érica, em seu relato, refere ao tempo cronológico da espera, já que ela se via sem condições de cuidar de Ari, como podemos ver abaixo:

No caso especifico do Ari o seu Acompanhamento Terapêutico foi muito esperado, né. Eu esperava muito e pedi muito (...), durante muito tempo vinha já sendo acompanhado (pela equipe do PSF) desde (...) inicio de 2001, era paciente que todo mundo já conhecia e era assim a gente já tava esgotando (...) Érica.

A dor psíquica, apresentada pelos nossos colaboradores, e bem percebida pelos agentes, muitas vezes, aparece como desamparo, solidão, dificuldades em executar tarefas e ainda, em se relacionar com o outro; nessa impossibilidade de estar com o outro, busca-se 
desesperadamente uma pessoa que possa ajudar ou que, muitas vezes, faça por ela essa tarefa, que é sentida como enfadonha ou que está acima da capacidade daquele indivíduo.

Percebemos que o sofrimento que esses moradores apresentaram mobilizou tristeza e instabilidade emocional vivenciadas pelas agentes comunitárias de maneira intensa, quando essas se depararam com o não saber o que fazer com a dor que estava sendo relatada, como o imobilismo existencial de Ari e Daniela; a falta de medicação ou uso incorreto dos remédios prescritos de Elaine e Vânia que causavam internações e afastamento delas da família, dos serviços de atendimento e da comunidade; e ainda os comportamentos disruptivos de Edivânia que colocavam em risco sua vida e do bebê que esperava, provocando brigas familiares.

\section{Sentindo-se perdida}

O agente comunitário sente-se limitado em sua capacidade de cuidar. Tem a função primordial de levar saúde nas suas visitas e orientações, servindo de elo entre o serviço de saúde e o usuário-morador daquele bairro.

Porém, durante a realização desta pesquisa, o que ocorreu nestas visitas, muitas vezes, foi encontrar pessoas da comunidade em sofrimento, o que, algumas vezes, as paralisou e as deixou sem saber o que fazer, já que as agentes, além de possuírem nível de instrução médio, não tinham treinamento específico, favorecendo, assim, o desenvolvimento de habilidades para atendimento em Saúde Mental, o que estão recebendo agora com o curso de aperfeiçoamento promovido pelo Estado.

(...) a gente já tava esgotando, já tinha esgotado todas as tentativas, todos os meios e tava ficando cansativo, eu mesmo tava me vendo perdida (...) tudo que fazia, nada dava resultado (...) Érica. 
Como profissional da saúde, as agentes comunitárias precisam, além do conhecimento técnico, de valores e atitudes humanas que dêem suporte para essas profissionais conduzirem seu trabalho nas visitas domiciliares.

No caso específico do PSF, do CSE da Vila Tibério, há reuniões quinzenais com a equipe do GEAVIDAS quando, entre outras coisas, são discutidas as famílias e ações pertinentes com o intuito, além de instrumentalizar, de dar apoio emocional às ACSs, propondo ações e terapêuticas viáveis a cada família.

\section{$3^{\text {a }}$ Categoria: Percepção do trabalho do Acompanhamento Terapêutico}

Heloísa valoriza o trabalho do at, principalmente ressaltando a melhora que percebe nos indivíduos que foram ou estão sendo acompanhados pela profissional. Fala da esperança que os clientes-colaboradores voltaram a sentir, o que ampliou as possibilidades deles e, portanto, a capacidade de enfrentamento de seus problemas, como podemos perceber no relato:

(...) é muito válido, é muito bom, a gente vê resultado assim nítido, não precisa tá vendo nem através de exames, a gente vê, a gente sente que as pessoas melhoram bastante (...) eles estão sempre buscando, (...), tá sempre assim com aquela esperança e com isso as coisas vão melhorando, o jeito deles, muda o comportamento (...) é (...) eles aprendem, captam muita coisa de bom pra eles (...) Heloisa.

Um outro aspecto da prática do at, trazido por Elizandra, foi o de ajudá-la a se organizar, a cumprir suas atividades e, também, a refletir com ela sobre os conteúdos que trazia, ampliando assim suas possibilidades. Seguem fragmentos do seu relato:

(...) deve ajudá-los a esclarecer um pouco, a perceber as coisas, a tentar definir (...) o que tá havendo, o que que tá (...) a tentar se organizar dentro daquilo que ele precisa, dentro daquilo que ele ta precisando no momento (...) a tentar fazer ele se organizar (...), o que tá acontecendo, o que que tá pegando (...) pra abrir um pouco os caminhos, pra ver qual é a dificuldade daquela pessoa, o que que tá acontecendo (...) Elizandra. 
Importante o aspecto que Érica aborda, em seu discurso, que é a ajuda que o trabalho de AT deu para Ari de se organizar em seus afazeres, se comprometer com sua saúde, seguindo os tratamentos no CAPS e contribuiu para que ele restabelecesse a esperança na vida e sua autoconfiança, como podemos ver em suas palavras:

(...) depois com a entrada do acompanhamento eu acho ele melhorou muito, muito mesmo, por mais que ele caia hoje, ele não tem mais aquela depressão que ele tinha antes. Antes ele tinha aquela coisa de não sair mais de casa, não fazer nada, não comer, não tomar banho, achar que a vida dele tava perdida, e hoje não mais, hoje ele tem os momentos de tristeza, de solidão de achar que ninguém quer, de que ele não tem felicidade, mas não tem mais aquela coisa, ele reage, (...) o seu acompanhamento fez com que, ele foi ao NAPS (atual CAPS) coisa que a gente nunca conseguiu, a gente não conseguia de jeito nenhum, ele não aceitava ele não ia (...) Érika.

Gabriela ressalta o trabalho do at que atende no ambiente do enfermo psíquico trabalhando com ele a partir de sua vivência cotidiana in loco, o que pode ocorrer em sua própria casa, como também nos vários lugares que a cidade oferece, como praças, shoppings, bares, etc., sendo o setting construído pelo acompanhante terapêutico no momento. Essa agente comunitária traz em sua fala o tempo de duração do trabalho e da percepção da melhora do indivíduo ao longo do tratamento.

(...) Como eu percebo? Ahhh eu acho que ajuda bastante. Assim (...) acho que você indo, acompanhando tando dentro de onde ele vive, da situação, vendo do ambiente tudo acho que ajuda bastante, acho que (...) no dia-a-dia você vai viver com ele aquela situação, né? Porque você chega lá, vai ta dentro do ambiente dele né. Aí ali você vai descobrir coisas que talvez no consultório você não consegue identificar (...) eu notei em determinados casos que começou a ter o acompanhamento terapêutico o que que aconteceu eles abrem aquele mundo deles que é fechado (...) então eu noto essas coisas que melhoram, por exemplo a Sonia não (...) era direto falando palavrão né, e eu acho que ela melhorou (...) Gabriela.

O AT se configura como tratamento quando as abordagens clássicas não são recomendadas ou não favorecem o tratamento do cliente e, ainda, quando há sofrimento que cause exclusão, impedindo o indivíduo de participar do seu meio social e incapacidade para organizar sua vida cotidiana com acesso a trabalho, estudo e/ou atividades de lazer.

O trabalho do at não ocorre de maneira isolada; precisa estar inserido em uma equipe de saúde ou, ao menos, com médico psiquiatra. Pode ocorrer desde o início do 
tratamento ou pode ser um agente em um processo de mudança, em uma crise psicótica ou até mesmo em situação específica, focal, em que o indivíduo não consegue sair dela sozinho.

A função primordial do AT é trazer o indivíduo para a realidade em que vive e refletir com ele as suas necessidades, porque, uma vez que as percebe, pode buscar satisfazêlas de maneira apropriada. Para Barreto (1998), Mauer e Resnizky (1987) resgatar o indivíduo de seu mundo particular pressupõe possuir a capacidade para conter, acolher, acompanhar e refletir com o paciente sobre suas ações.

Cenamo et al. (1991) e Mauer e Resnizky (1987) definem como funções do acompanhante terapêutico a de ego auxiliar, de modelo de identificação, de aliviar as ansiedades persecutórias, de agente socializador, de catalisador das relações familiares e interlocutor dos desejos e fantasias do paciente.

Essas são funções básicas do at que, ao longo dos atendimentos, ocorrem, muitas vezes, de maneira fluída e constante e são pensadas na emergência do momento. E, nessa situação, nos reconhecemos como seres sem condições para ajudar, o que não raras vezes, significa estar-com-o-outro na sua dor, ouvindo-o e refletindo com ele suas escolhas e possibilidades sem contudo, trazer respostas prontas e fechadas.

$\mathrm{O}$ at favorece que o indivíduo se perceba como ser de criação, de se lançar em busca da realização de seus desejos, vontades e, ao menos, de suas necessidades, como a de tomar a medicação de maneira prescrita pelo seu médico, favorecendo seu tratamento e sua melhora. Em outras situações o at ajuda o indivíduo em sofrimento psíquico a tomar decisões, como o de ir à consulta psiquiátrica (Ari), aceitar o tratamento (Vânia) a não ter comportamentos que coloquem em risco sua vida como sair à rua de madrugada quando se sente angustiada (Edivânia). 


\title{
Percebendo a melhora no tratamento a partir do trabalho do at
}

\author{
Gabriela percebe o outro, que tem um jeito próprio de ser, e, muitas vezes, \\ diferente de outros moradores cadastrados no PSF, que também visita, demonstra \\ sensibilidade para tratar esse outro de maneira distinta.
}

(...) ela já abre, quer que você entra, e insiste, aí o dia que você passa e só fala um oi ela fica diferente também, aí você muda até o seu jeito de tratar, por que você consegue identificar como você pode tratar um e como você pode tratar o outro (...) Gabriela.

Érica relata particularidades de um morador de sua área que estava mal, com dificuldades de ir e vir devido ao seu físico e também ao emocional debilitado, percebendo uma faceta do seu trabalho de visita domiciliar levando informações e orientações sobre saúde intercambiando, assim, a relação morador e posto de saúde.

(...) ele já tava num processo de melhora porque antes, no inicio ele (Ari) dava muito trabalho tinha vez que ele não conseguia sair, por diversas vezes eu fui na casa dele, assim ele não conseguia sair nem no portão ele tinha medo, (...) ninguém ligava para ele, ninguém gostava, a gente ia lá (...) Érica.

Percebemos, nas falas das agentes comunitárias, uma focalização na cura do paciente e uma necessidade em resolver o problema que ele apresenta, como se esse indivíduo fosse incapaz de resolver e fazer escolhas na sua vida de maneira responsável e coerente.

(...) eu acho, quando começou com a Sandra sem ir direto com a Da. Margarida (...) eu acho que no fim, a Da. Margarida participou mais, às vezes, do que até a Sandra. E essa participação da Da. Margarida influenciou a Sandra. Por quê? Melhorou (...) eu acho que essas coisas quando você começou a trabalhar (se refere ao trabalho da AT) isso quando a Sandra vinha queixar ou falar, não sei forma, né, como que usou, mas assim, ela (...) acho que amenizou tanto a briga com as duas (entre mãe e filha) (...) Gabriela.

Hycner (1995) acredita que uma das dificuldades do ser humano ocorre devido a sermos únicos e, mesmo assim, semelhantes a todos. Pensando nessa perspectiva, importante se faz refletir a dificuldade que o ser humano tem em aceitar um outro que se apresenta isolado do social por não se sentir capaz ou, ainda, por não querer participar desse espaço, 
sem ter uma causa aparente que justifique tal comportamento, como uma doença orgânica que aparentemente o incapacite.

Esse outro, enfermo ou não, tem particularidades que se apresentam, se bem ouvidas e significadas, como possibilidades de construção de novas cenas, mais adaptadas à sua condição de bem-estar e desejo, buscando novos horizontes e novas perspectivas.

Heloísa traz um outro aspecto dessa vivência, como agente em contato com as pessoas que visita, a esperança de que, suas visitas e os tratamentos com o AT propiciem uma revalorização do indivíduo e, conseqüentemente, maior e melhor qualidade de vida para os pacientes, como vemos abaixo:

(...) as pessoas que às vezes não tinha esperança nenhuma hoje já pensa, sabe, que quer viver mais, que quer melhorar mesmo que a gente saiba que às vezes uma doença não vai ter mais cura, porque às vezes já virou crônica, não tem mais solução (...) mas, pelo menos, eles ficam motivados e com vontade de viver (...) Heloísa.

\section{Acolhendo o paciente}

Heloísa refere à necessidade que algumas pessoas têm de serem acolhidas, ouvidas e enfim reconhecidas e tratadas como seres humanos, como vemos abaixo:

(...) mesmo que às vezes eles nem seguem direito, não fazem o que a pessoa pede, que orienta, mas pelo menos eles têm com quem contar (...) com aquela pessoa, e pra muitas pessoas isso foi muito bom (...) Heloísa.

Gabriela ressalta, em sua fala, a demonstração desse acolhimento quando relata a possibilidade de ajuda que os moradores da sua área de abrangência trazem em seus discursos.

(...) tem a Dra. Marciana no pedaço, tem a Gabriela (agente comunitária) (...) Gabriela.

Corroborando com esse comportamento de distanciamento, percebemos a atuação do agente comunitário que sente-se impotente frente à dor do indivíduo enfermo mental e, muitas vezes, busca fazer pelo outro, antecipando-se a ele, na tentativa de aliviar seu 
sofrimento como se fosse obrigado a resolver os problemas dele como única forma de ajudálo.

\section{Abrindo-se para o outro}

Gabriela, na sua fala, enfatiza que, para entrar em contato com os moradores, teve dificuldades com alguns deles por ver, em primeiro lugar, a doença ou deficiência, como aconteceu no caso de Sandra, moradora da área de abrangência dela, portadora de síndrome de Down, que demorou a ser visitada pelo medo que Gabriela tinha de lidar com a paciente, medo que acontecesse alguma coisa durante a visita.

(...) E eu acho que depois que começou assim, além das visitas, por que no início pra visitar era difícil também, por que eu passava, olhava e falava oi (...) e ela: (respondia) oi e eu não entrava porque (...) (tem) síndrome de Down mora, tá sozinha em casa, vai que acontece alguma coisa pode achar (...) o dia que você passa e só fala um oi ela fica diferente também, aí você muda até o seu jeito de tratar, porque você consegue identificar como você pode tratar um e como você pode tratar o outro (...) Gabriela.

Além de suas funções como agente comunitária, é muito importante que esse profissional atue junto com a comunidade, vinculando-se aos serviços que o bairro oferece, favorecendo não somente a saúde mas a prevenção de doenças e a promoção da saúde com ações educativas e sociais. Estar com o outro exige do profissional a abertura para ouvir, estar junto sem, contudo, trazer respostas prontas, fechadas, como sendo a verdade.

\section{Categoria: A percepção do tempo no tratamento}

Percebemos que, na visão dos agentes comunitários, o portador de sofrimento psíquico apresenta uma necessidade imediatista, tem urgência de sair da dor emocional, 
representada pela angústia, medo, desânimo, euforia exacerbada que, muitas vezes, o acomete e o enfermo psíquico não sabe muito bem o que fazer, como o discurso abaixo retrata:

(...) daí um tempo, (...) daí um período (...) dependendo do caso, nem seja necessário mais (...) (atendimento psicológico) por ter assim, resolvido mesmo sabe posto a esclarecer mesmo as coisas (...) Elizandra.

Érica refere-se à busca de resultados grandiosos que possam ser vistos e demarcados com toda a possibilidade, sem nenhum engano.

(...) na realidade dava (o paciente tinha melhora), só que era aquele resultado lento que a gente não percebe muito, a gente costuma perceber só os resultados mais evidentes mesmo (...) Érica.

Gabriela, em sua fala, constata que a melhora do enfermo mental é lenta e ocorre segundo o tempo do próprio indivíduo e não do profissional que o atende. Não é um tempo cronológico ou mesmo quantificável.

(...) às vezes pode até você achar que aí não tá adiantando nada, né, em determinada visita ou determinado acompanhamento (...) aí depois você vai ver que no final assim, dum certo tempo, você vê como muda as coisas (...) Gabriela.

Silva retrata em suas palavras a angústia das agentes comunitárias: “(...) Tempo de decantação, de espera, mas também tempo de produção de um ato, é disso que se trata na condução da cura. Tempo outro que não o cronológico, tempo único e singular daquele que sofre (...)” (SILVA, 2004, p.144-5).

Esses indivíduos vivem o sofrimento por, muitas vezes, precisarem de tratamento de longa duração que os distancia de sua vida, anterior à doença. Nossos colaboradores apresentam quadro cronificado de vários anos de tratamento e, não raro, diversas histórias de abandono do tratamento e retorno com a agudização dos sintomas.

O enfermo mental se percebe como ser limitado em sua vontade, em sua potência, em seus desejos e como tal, limitado em sua existência. Nessas circunstâncias apresenta debilidade em cuidar-se, adoecendo, o que pode se manifestar como depressão (Ari), desmotivação (Ari), comportamentos disruptivos com compras excessivas sem condições de 
saldar suas dívidas (Daniela e Elaine) ou saídas pela cidade em momentos de forte angústia, colocando em risco sua vida (Edivânia), e ainda, comportamentos inadequados como xingamentos (Sandra). Essa limitação pode se apresentar também através de delírios e alucinações, dificuldades em gerir sua vida de maneira satisfatória como comprar seu próprio alimento, fazer sua comida, cuidar de sua casa (Vânia).

Esse adoecimento remete à finitude do ser, em suas inúmeras possibilidades, como uma certeza de ser-para-a-morte. "Não se trata da certeza cartesiana, tampouco da certeza do perecer, mas a da possibilidade da morte a todo instante, em sua própria indeterminação" (DUBOIS, 2004, p. 50). Como possível irrefutável, ninguém a questiona, mas quando a percebe tão próxima, como quando em processo de adoecimento, o portador de sofrimento psíquico se percebe limitado, com restrições que sua enfermidade lhe imputa como o sofrimento psíquico, o desconforto do aprisionamento de não conseguir realizar muitas atividades que antes eram fáceis como cuidar de si, de suas coisas, de sua casa, tomar decisão, dentre outras possibilidades.

\section{Categoria: Percebendo a solidão do outro}

Heloísa percebe e relata o distanciamento que o portador de sofrimento psíquico mantém do mundo e das pessoas ao redor. Esse elo foi cortado, deixando-os sozinhos.

(...) esses problemas (...) que não tem com quem conversar, que nunca tem um familiar que, (...) eles sentem uma necessidade muito grande de ter alguém pra poder tá falando (...) Heloísa.

Percebemos que o portador de sofrimento psíquico vive à margem, muitas vezes, porque não consegue fazer essa ponte com seus familiares, seja pela mágoa que uma das partes sente, seja pela dificuldade de se relacionar com o outro partilhando com ele suas dores e alegrias, experienciando, assim, um isolamento existencial. 
Nos dizeres de Yalom (1996), isolamento existencial é uma lacuna instransponível entre os indivíduos, lacuna que existe independente de relacionamentos interpessoais

profundamente gratificantes. É do ser humano, faz parte do seu mundo e, sendo assim, pode apenas ser diminuído, aplacado pelo outro, como no presente estudo, o at, agentes comunitários e/ou profissionais de saúde.

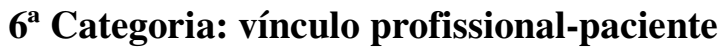

Gabriela referencia a vinculação que o paciente consegue estabelecer com o profissional de saúde como facilitador no tratamento dele.

(...) a pessoa já te espera, já fica brava se você não vai, cobra de você, (...) então eu acho que ela cria, ela cria um vínculo que ela acha que é uma pessoa que vai lá pra tá ajudando (...) ele (a paciente e, muitas vezes o familiar também) abre (conta) tudo prá você, então fala tudo de coisas mais íntimas às vezes começa abrir, tá falando dos problemas que tem na família e vai te colocando (...) Gabriela.

O vínculo pode ser considerado um dos elementos essenciais de uma prática clínica de qualidade, particularmente na área de saúde mental, e poderá cumprir dois objetivos na reforma dos serviços públicos: aumentar a eficácia das ações de saúde e introduzir, no espaço dos serviços públicos, uma das formas de controle mais efetivos, uma vez que será feito pelos próprios interessados, ao mesmo tempo em que eles recebem os cuidados de saúde de que necessitam (CAMPOS, 1992).

Vale ressaltar também que o envolvimento da família no tratamento do doente e, em especial, do doente mental é fundamental para sua recuperação. O vínculo estabelecido(,) entre a equipe de saúde e a família, favorece a adesão e participação desta no tratamento, bem como do próprio paciente, e ao mesmo tempo poderá atender essa família e apoiá-la em suas dificuldades, isto porque a doença não traz sofrimento somente ao indivíduo mas também ao grupo familiar, portanto ambos precisam de apoio e assistência (ROSA, 2002). 


\section{$7^{\text {a }}$ Categoria: Insegurança}

Gabriela relata a angústia e insegurança que sente no trabalho como agente comunitária se deparando com o indivíduo enfermo mental que, não raras vezes, em sua especificidade expõe essa profissional à pequenez de sentir que não sabe o que fazer na dada situação. Em momentos como esse, vivencia o desespero de não compreender o que está acontecendo e como poderia lidar com essa situação.

(...) você fica numa certa corda bamba (...) Gabriela.

Atender o enfermo mental, muitas vezes, impacta o agente comunitário com a insegurança de não compreender o que está acontecendo ou qual a causa do imobilismo do morador-enfermo-mental.

O trabalho com o portador de sofrimento psíquico propicia a vivência de obstáculos e dificuldades ao profissional de saúde que os atende. Dificuldades essas que podem ser enfrentadas com cursos de capacitação, treinamentos, supervisões e com as reuniões de equipe em que soluções são pensadas junto com outros profissionais.

\section{$8^{\text {a }}$ Categoria: Importância do trabalho do Acompanhamento Terapêutico}

Pensar o enfermo mental nos remete a distanciamento, solidão, isolamento. Percebemos na fala de Heloísa a necessidade que o indivíduo sente de pertencer e fazer contato com o outro que permita a ele ser ouvido e, também, que ele ouça, podendo assim participar dessa relação de maneira autêntica.

(...) é muito bom, é muito importante, eles se sentem bem com essa presença, por que eles gostam de falar muito, de contar de seus problemas, de ouvir também a gente. Eles ouvem muito a gente e acaba melhorando a vida, a vida fica mais (...) fica menos pesado (..., pra eles (...) Heloísa. 
Gabriela, em seu discurso, ressalta a função do at de servir como modelo de identificação para ajudar esse indivíduo a restabelecer os vínculos consigo mesmo, com a comunidade e com os serviços especializados de tratamento em saúde.

(...) é importante o acompanhamento terapêutico, eu acho que muitas pessoas assim se beneficiam disso né, assim pelo menos como ponto de partida dela tá saindo de casa, tá indo participar em grupo ou tá indo até para procurar o serviço (...) eu acho que devia ter mais acompanhantes terapêuticos, mais profissionais que se interessem por acompanhamentos terapêuticos (...) Gabriela.

Érica percebe que a vinculação do indivíduo à sociedade, seja a comunidade onde ele vive, seja os serviços de saúde, é fundamental e que, muitas vezes, para isso, precisa de um profissional como o at, com formação e habilidades específicas para fazer essa ponte.

(...) Pra pacientes como ele (Ari) era, eu acho que é essencial, acho que o cuidado, só o nosso cuidado aqui que é cuidado de saúde não é suficiente, não era tanto que essa melhora aparente dele, maior só veio depois do acompanhamento (AT) porque antes às vezes a gente se via perdido. Eu acho que é necessário, é um elo necessário. A gente precisa de apoio mesmo pra esses pacientes (...) Érica.

Buscamos, junto ao paciente, uma aceitação de si mesmo e de sua condição de ser-no-mundo-portador de enfermidade psíquica não como ponto final, mas como ponto de partida favorecendo, assim, uma nova consciência de si levando-o a buscar outros caminhos para o seu desenvolvimento pessoal e melhor adaptação ao seu ambiente. Nessa perspectiva percebemos a aceitação da diferença em detrimento da ilusão da igualdade,o que favoreceu o tratamento dessas pessoas.

Nessa perspectiva, o at não foi somente o profissional que cuidou, quando outros tinham tentado fazer, porém sem sucesso. Nem tampouco foi aquele profissional que atendeu o enfermo psíquico desarticulado dos outros profissionais que, direta ou indiretamente, atendiam esse indivíduo. Pelo contrário, é o at serviu de elo entre a equipe e o indivíduo ou a equipe e a família, como ocorreu com Vânia, Daniela, Ari, Edivânia, Elaine, Sandra.

$\mathrm{Na}$ limitação do enfermo psíquico a at esteve presente com intuito de estar com ele, mesmo que naquele momento específico nada tivesse a fazer, acompanhou-o na sua dor 
(Ari, Edivânia, Daniela, Elaine), isolamento (Ari, Daniela), distanciamento do mundo real (Vânia, Elaine). Em outras ocasiões, a at serviu de identificação a esse ser em sofrimento, quando seus modelos estavam rompidos, mostrando, assim, novos horizontes para esse indivíduo (Ari, Elaine, Edivânia).

Após o exposto discorrermos, no próximo tópico, a interpretação do fenômeno, que ora buscamos conhecer, à luz do pensamento de Martin Heidegger.

\section{2 - A vivência da enfermidade mental: percepções e sentidos se desvelam à luz do pensamento de Heidegger}

A partir das unidades temáticas, vistas no item anterior, e com intuito de compreender a percepção e os sentidos que os colaboradores desta pesquisa têm do acompanhamento terapêutico, buscamos, em Martin Heidegger e autores que se aprofundaram nesse enfoque, subsídios para tal intento sem, contudo, termos a pretensão de esgotar o assunto nem tão pouco, impor nossa compreensão como única possível.

Nos discursos dos colaboradores deste trabalho, pudemos apreender dificuldades comuns ao enfermo psíquico bem como aos familiares deles e profissionais de saúde que trabalham com essas pessoas. Percebemos, por exemplo, a dificuldade do indivíduo em aceitar ajuda já que tem aversão a esse cuidado, a agressividade, a dificuldade em aceitar a doença e o uso dos medicamentos já que estes impõem a eles, muitas vezes, restrições a bebidas e causa efeitos colaterais, a dificuldade em lidar com as incertezas que a doença traz e a impotência de conviver com um ser-enfermo-mental, bem como a percepção que essas pessoas tiveram do acompanhamento terapêutico como instrumento de tratamento. 
Nessa perspectiva analisaremos essa compreensão segundo as dimensões existenciais da cotidianidade, da angústia, da temporalidade, do cuidado, da facticidade, dos modos de existir autêntico e inautêntico.

Para Heidegger, o homem, em sua estrutura de ser-aí se encontra em estado de abertura para sua existencialidade, não sendo, a priori, mas enquanto ser, no vindo-a-ser em suas vivências no mundo, experimentando e se constituindo. Ele vai se construindo nas suas relações, de acordo com seus valores, suas crenças, e suas experiências, participando como ser-no-mundo em um constante vir-a-ser. Esse processo é difícil para o enfermo psíquico que, muitas vezes, rompeu ou tem dificuldades em manter esse contato com o outro.

O enfermo mental vive no distanciamento com o outro, seja pela exclusão que sofreu, e ainda sofre, seja por si mesmo, que não consegue estabelecer relação com os outros ou, ainda, por não achar falta do outro e, assim, se ausenta, muitas vezes, se isolando ou distanciando desse contato. Nessa condição, demonstra dificuldade em buscar quem possa se relacionar de maneira satisfatória com ele, em um contato que lhe possibilite ser ouvido e ouvir, interagindo com as pessoas ao seu redor e, assim, se realizando como ser-com-o-outro.

Esse adoecimento nos remete à finitude do ser, em suas inúmeras possibilidades, como uma certeza de ser-para-a-morte. "Não se trata da certeza cartesiana, tampouco da certeza do perecer, mas a da possibilidade da morte a todo instante, em sua própria indeterminação" (DUBOIS, 2004, p. 50). Como possível irrefutável, ninguém a questiona, mas quando a percebe tão próxima, como quando em processo de adoecimento, ele se percebe limitado, com restrições que sua enfermidade lhe imputa como o sofrimento psíquico, o desconforto do aprisionamento de não conseguir realizar muitas atividades que antes eram fáceis como cuidar de si, de suas coisas, de sua casa, tomar decisão etc. Para pensar serportador-de-enfermidade-psíquica em sua possibilidade nos remeteremos ao ser-aí. 
O ser-aí é o indivíduo com suas características próprias que vivencia e se lança ou é lançado, no mundo. A sua essência está fundada em seu existir. Para Heidegger (1988), o sentido de ser é muito mais profundo que pensar a existência do homem. Em seus questionamentos, ele parte do sujeito inserido no mundo como um ser de pre-sença - o ser-aí - que vive em relação com as coisas, com os outros e com o mundo. Na perspectiva do ser em sofrimento psíquico ele necessita que alguém - outro - faça esse papel e o ajude a transpor essa barreira que o distancia e isola, enclausurando-o na sua patologia.

(...) o homem só se realiza na presença. Presença é uma abertura que se fecha e, ao se fechar, abre-se para a identidade e diferença na medida e toda vez que o homem se conquista e assume o ofício de ser, quer num encontro, quer num desencontro, com tudo que ele é e não é, que tem e não tem. É essa pre-sença que joga originariamente nosso ser-no-mundo (HEIDEGGER, 1988, p. 20).

Nesse sentido, ser-aí só é possível enquanto ser no mundo, ser de relação que é construído a partir das interações que o indivíduo estabelece no cotidiano. Ele não está pronto, acabado e, nem tão pouco, pode existir fechado em si mesmo. Nos dizeres de Heidegger, “(...) ser-no-mundo mostrou que, de início, um mero sujeito não 'é' e nunca é dado sem mundo. Da mesma maneira, também, de início, não é dado um eu isolado sem os outros” (HEIDEGGER, 1988, p.167).

O indivíduo, na visão heideggeriana, é ser-aí e também aí-com, dentro-do-mundo, inserido em um contexto histórico de sua família, de sua casa e, porque não dizer, de sua história de vida. Ressaltamos que ele é um ser de relação consigo e com o mundo. E o encadeamento de sua vida com as escolhas feitas, os projetos construídos, sonhados e suas realizações alicerçam o indivíduo no mundo.

Portanto, “(...) ser no mundo é uma estrutura de realização (...) por sua força, tudo se compreende numa conjuntura de referências (...)” sendo assim “(...) o homem não é 
uma coisa simplesmente dada nem uma engrenagem numa máquina e nem uma ilha no oceano” (HEIDEGGER, 1988, p. 20).

Nesse sentido, a partir do ser-no-mundo, o indivíduo se relaciona com os entes e outros seres. Heidegger (1988) chama nossa atenção para a interação como possibilidade para o indivíduo ser-no-mundo. Desde bebê, o indivíduo descobre-se no mundo através da interação da mãe ou de alguém que se coloca nesse lugar. Ao longo da existência, nos percebemos como sujeito de trocas mesmo que indiretamente.

Cada gesto humano é sempre um fazer nascer algo novo ou de novo e, assim, iniciar uma trama que vai se complementando pelos outros, que, por sua vez, também por seu gesto, vão iniciando algo novo ou de novo [...] na forma dessa trama de realização através da qual vamos habitando o mundo e, através de tal habitação, vamos nos revelando o próprio mundo (CRITELLI, 1996, p. 102).

$\mathrm{O}$ ser se estabelece enquanto ser-com-o-outro-no-mundo-vivido. Ele é um ser acontecendo e, assim, se apropria de sua existência. Como vemos nas palavras a seguir: “(...) na base desse ser-no-mundo determinado pelo com, o mundo é sempre o mundo compartilhado com os outros. O mundo da pre-sença é mundo compartilhado. O ser-em é sercom os outros. O ser-em-si intramundano destes outros é co-presença (...)” (HEIDEGGER, 1988, p. 170).

O ser humano só existe no ser-com que já está dado a partir do mundo que existe. Só existimos porque antes fomos pensados, desejados, concebidos e nos descobrimos como ser-com-o-outro. O desejo, na convivência com o outro, nem sempre aparece, seja porque é inexistente no enfermo psíquico seja pela incapacidade de demonstrá-lo.

Essa relação que o indivíduo estabelece com o outro e com o mundo ao seu redor orienta e estrutura seu modo de existir no mundo. Essa interação ocorre em um constante vaivém entre o que é dado na situação e a realidade que se desvela na compreensão. 
Compreensão que, para Heidegger, desenvolve-se antes da tomada de consciência reflexiva, do mesmo modo que a situação se manifesta antes da reação afetiva.

(...) A existência de que nos fala Heidegger é ek-stática. Caracteriza esse ente denominado Dasein, capaz de ser aquilo que projeta ser, de sair de si próprio, de ek-sistir (...) o Dasein é aquilo que ele pode ser. Ser, para ele, é poder ser este ente concreto, empenhado no mundo, cujo ser é permanentemente posto em jogo e como que arrancado de si próprio. A essência do Dasein não significa, portanto, o caráter estável e invariante daquilo que é, não é uma definição abstrata definitivamente válida (...) (PASQUA, 1993, p. 36).

Viver é con-viver ou viver-com, vai além do funcionamento biológico, requer um se lançar para o outro, seja ele ser, ou seja, ente. Nessas interações há troca de idéias, emoções e sentimentos. Esse se lançar é do humano, do ser e não do ente, como vemos abaixo.

(...) Esqueceu-se que ser não é uma substância, nem mesmo abstrata; que não é um objeto, uma coisa; que ser é simplesmente o modo daquilo que é. O ser não é uma forma substantiva, mas verbal. Ser não é um substantivo, apenas o verbo ser na sua forma infinitiva. Ser é movimento; ser é sendo. Por ser modo de estar sendo do ente, por ser possibilidade em aberto, o ser não pode ser precisado, objetivado, aprisionado num único sentido (...) (CRITELLI, 1981, p. 14).

De acordo com o pensamento de Heidegger, a essência humana é configurada pela relação com o ser (DUBOIS, 2004), o que nos leva a refletir que o at, quando proporciona o encontro do enfermo-psíquico consigo mesmo, através da ressignificação de sua história de vida, favorece que essa essência apareça, e o indivíduo vivencie a liberdade de existir e estabelecer relações mais autênticas com o mundo.

A dinâmica de ser-no-mundo, sendo no instante, constitui o fenômeno da verdade, que é denominado descoberta ou aparecer, uma vez lançado no mundo de um modo factual. O ser humano habita o mundo, é familiar e co-agente neste mundo, sendo um ser de possibilidade, já que é projeção do ser e pode assumir diversas maneiras de apreender e relacionar-se com o mundo. E, como possibilidade, ele se lança em sua condição ontológica, fundamentalmente poder-ser, como um projeto, o que lhe outorga a responsabilidade e a 
obrigação de ser enquanto existente no mundo, assumindo os riscos e as oportunidades de tal intento.

Esta perspectiva impulsiona o indivíduo ao movimento, à vida sem, contudo, dar garantia de um resultado, porque é possibilidade de realização. “(...) assim, o homem é nomundo realizando o mundo, as coisas do mundo, os outros e a si mesmo. Realizar é mais do que empreender, é desvelar, testemunhar, (...), autenticar” (CRITELLI,1996, p. 102).

O mundo circundante do enfermo psíquico abrange o relacionamento dele com as pessoas do seu ambiente e a maneira como esse relacionamento ocorre. Por um lado, ele está dado e temos que nos adaptar a ele, porque é caracterizado pelo determinismo e, por outro, não está fechado como um animal enclausurado, porque ele habita no mundo com todas as possibilidades que sua consciência lhe permite.

Nesse sentido percebemos que a at, ao longo do tratamento, ampliou essas possibilidades favorecendo a ampliação dos movimentos de Ari, Vânia, Elaine, Edivânia, Daniela, Sandra, dentro das suas dificuldades e limitações, uma vez que cada um a seu modo pôde buscar seu caminho com mais liberdade e satisfação. Nesse sentido, com exceção de Margarida, que não percebe mudanças positivas em Sandra, todos os colaboradores-familiares relataram a percepção das mudanças ocorridas com seus familiares.

Percebemos, também, um contato insatisfatório dos colaboradores-clientes com seus familiares e destes com eles, o que pode explicar a deficiência desta escuta expressa por Heidegger e que favoreceria o encontro do enfermo mental com o outro. Nesse sentido, é importante esclarecer que compreendemos esse encontro e os desencontros relatados como ocasionados por ambos os lados, já que as relações estabelecidas por nossos colaboradores, foram pautadas, muitas vezes, por um contato deficitário entre eles.

No discurso, a pre-sença se pronuncia. Entretanto, isso não ocorre porque a pre-sença se acharia de início, encapsulada num "interior" que se opõe a um exterior, mas porque, como-ser-no-mundo, ao compreender, ela já se acha 
"fora". O que se pronuncia é justamente o estar fora, isto é, o modo cada vez diferente da disposição (ou do humor) que, como se indicou, alcança toda a abertura do ser-em (HEIDEGGER, 1988, p. 221).

Para este filósofo, comunicar pressupõe movimento de pre-sença de um ser em direção a um outro ser. "Escutar é o estar aberto existencial da pre-sença enquanto ser-comos-outros (...) a pre-sença escuta porque compreende" (HEIDEGGER, 1988, 222).

Para esse filósofo, a escuta é uma maneira simples de falar e demonstra uma dimensão profunda com o outro indivíduo “(...) a escuta é a dimensão mais profunda e o modo mais simples de falar (...) no silêncio, o sentido do ser chega a um dizer (...) que sempre se faz sentir, tanto na presença como na ausência de qualquer realização ou coisa" (HEIDEGGER, 1988, p. 15).

Nessa perspectiva observamos que a at ajudou os colaboradores-clientes a estabelecerem relações com-o-outro, mais prazerosas e pautadas em um contato mais verdadeiro e positivo. Ari, Edivânia, Sandra, Vânia, Daniela, Elaine demonstraram, ao longo dos acompanhamentos, uma mudança saudável na maneira como se relacionavam com as pessoas ao seu redor. Aventamos que esse contato pode ter sido favorecido pela comunicação mais aberta e fluída entre eles.

Um outro aspecto percebido nas falas dos colaboradores, tanto dos familiares como dos agentes, foi a dificuldade em cuidar de um indivíduo portador de enfermidade psíquica devido às incertezas, ambigüidades e à angústia que se fizeram presentes.

Se por um lado esse contato do familiar com o enfermo é pautado pelo desencontro e pelas dificuldades, muito comuns do contato com a pessoa portadora de enfermidade mental, por outro, denuncia as limitações e deficiências que já existiam nesses relacionamentos, antes do adoecimento, como a falta de diálogo, a impaciência ou nãoaceitação do outro, a raiva, as expectativas que, muitas vezes, são depositadas nas agentes comunitárias que, não raras vezes, se vêem sem saber o que fazer e se mostram inseguras e 
com dificuldades em acolher esses moradores. Observamos, ainda, que os familiares e as agentes tinham a expectativa que o tratamento com a at mostrasse uma melhora rápida, como uma necessidade imediatista por solução que fosse duradoura.

Um outro aspecto, explicitado pelos colaboradores, foi a facticidade do serenfermo-mental que requer assistência médica, quando ela se percebe ser com limitações pode se abrir como possibilidade e vivenciar de maneira autêntica sendo ser-no-mundoconvivendo-com-a-enfermidade-mental sendo portador, familiar de um portador ou profissional que trabalha com essas pessoas com sofrimento psíquico sendo absorvido por esse mundo, como aconteceu com - os colaboradores-clientes - Ari, Elaine, Vânia, Daniela e percebido pelos familiares Aleandro, Da. Társia, Vanildo, Josué, respectivamente e, também, pelas agentes.

Uma vez que ocorre essa sensibilização, percebemos que cada um a seu modo e com seus conhecimentos amplia seus horizontes e consegue vislumbrar outras possibilidades de tratamento para as dificuldades e limitações que a enfermidade psíquica impõe ao humano.

Para a perspectiva heideggeriana, é na medida em que o ser-com se revela como ser-si-mesmo e, portanto, ser autêntico, que se torna capaz de compreender o outro da maneira que é como ser de possibilidades, respeitando-o como ser humano em sua maneira singular de existir no mundo.

Percebemos que quando o indivíduo não consegue esse encontro com o outro ele se angustia, o que favorece a busca por ajuda ou encontro com ele mesmo e com o outro, como vemos a seguir.

A angústia favorece uma abertura abrangente, em que o ser-aí vem ao encontro de si mesmo de uma maneira privilegiada. O indivíduo se angustia e essa angústia o remete ao poder-ser-no-mundo, abrindo-se a si mesmo para a possibilidade. Nesse caminho, o ser-aí transcende, abrindo-se ao sentido e à existência do ser (HEIDEGGER, 1988) que é própria a 
cada um de maneira particular. É através da angústia que o indivíduo transpõe o não-eu ao eu e assim tem a oportunidade de se reencontrar.

Nesse sentido o at favoreceu a percepção desses momentos de angústia não como algo instransponível ou eterno, mas como momentos importantes e inerentes ao humano.

Os colaboradores-clientes denunciam a angústia de ser-doente mental com limitações e deficiências próprias da enfermidade psíquica e que os aprisionam enquanto eles não conseguem aceitar e reconhecer essas deficiências e irem além transformando a si mesmos e à sua realidade, abrindo, portanto, novas possibilidades para ser no-mundo.

A angústia aparece nos relatos dos familiares, quando eles não percebem o seu parente capaz de ser-com-o-outro em sua singularidade. Percebemos, então, angústia que os aprisiona distanciando-os do ser-portador-de-enfermidade-psíquica.

Já as colaboradoras-agentes relataram angústia e insegurança que sentem no trabalho como agente comunitária se deparando com o indivíduo enfermo mental que, não raras vezes, em sua especificidade expõe essa profissional à pequenez de sentir que não sabe o que fazer na dada situação. Em momentos como esse, vivenciam o desespero de não compreender o que está acontecendo e como poderiam lidar com essa situação.

Questionamos se a angústia da agente comunitária frente ao desconhecido, de não saber cuidar, de não saber o que fazer é por não se reconhecer como possibilidade de cuidar do outro, principalmente, devido à dor que a proximidade com uma pessoa em sofrimento psíquico pode causar nesse profissional.

Para existir, o ser tem de se apropriar de si mesmo, o que pode ocorrer de modo próprio ou impróprio na relação de realização consigo mesmo e não em um conteúdo dado previamente. Portanto, o ser-meu é condição de propriedade e de impropriedade, que são as modalidades fundamentais da existência, e não possui o caráter de um pólo egóico substancial (DUBOIS, 2004). 
(...) eu passei por vários momentos difíceis e cheguei ao ponto de preparar o suicídio (...). Ari

Para Heidegger, Ari apresentou uma maneira inautêntica ou imprópria de se relacionar no mundo. Quando pensou em preparar o suicídio, ele se abandonou, deixando-se levar para qualquer lugar e, ao mesmo tempo, para lugar nenhum, em uma passividade que o esvazia enquanto ser. Como explicita Critelli: “A impropriedade, inclusive, é um dado revelador da ontologia humana, quer dizer, damos mostra, inequivocadamente, que a coexistência (...) é condição na qual a vida é efetivamente dada ao homem (...)" (CRITELLI, 1996, p.65).

Ressaltamos que, esboçando uma crítica à maneira como Ari, Sandra, Edivânia e Vânia se comportavam, Aleandro, Margarida, Vagner e Vanildo, respectivamente, expressam não compreendê-los se configura como relacionamento inautêntico. Caracterizado pela indiferença e, expressado pelo estar com o outro sem se importar com ele, apoderar-se do outro, mantendo-o a distância, ir contra o outro, o relacionamento assume caráter de afastamento.

Esse distanciamento dificulta o estabelecimento do ser-com-o-outro, já que, para esse filósofo, é somente como ser-no-mundo que o homem se lança às possibilidades de aprendizado, amadurecimento e cuidado de si e do outro.

Outro aspecto dessa vivência inautêntica é expressa pelas falas das agentes comunitárias, quando demonstram angústia que sentem em alguns atendimentos com indivíduos portadores de sofrimento psíquico, quando demonstram um sofrimento emocional que a agente comunitária não sabe cuidar.

Heidegger (1988, 1981) chama nossa atenção para o fato que, no cotidiano, existimos na superficialidade com uma consciência de nós mesmos muito pálida do nossoser-no-mundo. Freqüentemente, nós nos projetamos sobre as coisas, sobre nossos desejos e 
necessidades e nos relacionamos com os outros de modo a não sermos nós mesmos, mas agente, ou seja, estamos constantemente mergulhados e perdidos no ser-nós e no ser-eles.

Este modo de ser do homem - que Heidegger - classifica como inautêntico da eksistência tem uma significação ontológica: ela expressa o esforço do Dasein na sua busca da familiaridade para escapar a um confronto com o ser (MICHELAZZO, 1999). E é desse modo que as agentes comunitárias se expressam quando se sentem sozinhas, incapazes de entender e partilhar o sofrimento do morador-enfermo mental sem, contudo, se antecipar e fazer por ele, como muitas vezes ocorre com as agentes.

Pode-se por assim dizer, tomar conta do outro ou colocar-se em sua posição de cuidar pode-se saltar sobre o outro. Este modo de solicitude é o que assume o encargo que é do outro de cuidar de si mesmo. O outro é lançado fora de seu próprio lugar; ele retrocede quando algo precisa de sua atenção, ou mesmo pode tomá-lo como alguma coisa já acabada e à sua disposição, ou ainda desencarregar-se dele completamente. Em tal solicitude o outro pode tornar-se alguém que é dominado e dependente, mesmo que esta dominação seja, para ele, tácita, ou lhe permaneça oculta (HEIDEGGER, 1981, p. 41).

Heidegger (1981) nos remete à inautenticidade em que o indivíduo pode estar indiferente ao outro, como se ele não existisse ou ainda não se interessasse por ele. Observamos em Margarida uma forma de se relacionar com Sandra não desinteressada, mas deficiente porque não consegue ver sua filha crescendo, descobrindo coisas diferentes, interagindo com o meio ao seu redor, lançando-se no mundo, mesmo com suas dificuldades e limitações.

Aleandro demonstra uma maneira inautêntica de cuidar, quando faz críticas ao modo de vida de Ari, que são diferentes da dele, despersonalizando-o e buscando nas regras morais a explicitação das falhas do irmão e a comprovação de sua errância com o uso de drogas, vida boêmia, desentendimento conjugal com a segunda mulher.

Uma dessas limitações é a solidão, expressa por Ari e Edivânia, que dificultou a busca pelo outro - familiar, equipe de saúde -, o que, para Heidegger (1988), fundamenta a 
existência, visto que, na relação, o homem estabelece com o mundo o que ele é-no-mundocom-o-outro. Somente é possível pensar o ser em contato com o mundo, em relação com outro ente ou outro ser.

Outra limitação é expressa por Elaine quando explicita a dificuldade em administrar sua vida de maneira assertiva, percebendo suas deficiências e impedimentos que favoreceriam um relacionamento mais maduro com seus familiares, já que é somente quando nos percebemos deficientes, ou em falta, podemos ir em busca do que nos falta. Para Heidegger (1988), a imaturidade faz parte do ser, e com ela vem a completude e as novas possibilidades que explicitam novos campos e, portanto, novas imaturidades a serem vencidas em um processo constante do vir-a-ser do homem.

Foi possível captar nas falas dos familiares a ambigüidade que se manifesta na convivência com o enfermo psíquico, ora o percebendo limitado e necessitando de cuidado e assistência, sendo incapaz de sozinho fazer por si e, ora o tratando como potente e capaz de gerir sua vida sozinho, como vimos no relato de Aleandro, Margarida e Vanildo.

Essa ambigüidade apareceu também nos discursos de Vagner, Josué sem a intenção de deturpar ou distorcer, se fazendo presente na convivência, caracterizando o modo em que a presença realiza o seu "pre" e, portanto, a abertura do ser-no-mundo (HEIDEGGER, 1988).

Retomando o conceito de historicidade em Heidegger, observamos que como ser histórico, o ser-aí se constrói na temporalidade que é factual e construída pelo encadeamento da vida, compreendido por nós pelas fases de desenvolvimento que todos nós, seres humanos, passamos e que tem a idade como guia de demarcação, mas que é vivenciado por cada um de maneira única. É essa vivência que permite ao indivíduo se perceber como ser de possibilidades, e se lançar a elas. 
Heidegger (1988) nos fala de uma dimensão do nosso existir que é temporal. Uma característica do ser é poder pensar o futuro como possibilidade, como perspectiva de vir a ser. Como vemos, por exemplo, com Ari que faz planos de constituir uma família com uma outra esposa. Vânia que alicerça suas atividades nos cuidados dispensados aos pais. Sandra nos projetos de atividades e autocuidado. Nas agentes que manifestam a esperança de ver os moradores atendidos por elas, livres do sofrimento psíquico e vivendo com qualidade de vida.

No mundo cotidiano, a temporalidade se configura por momentos demarcados por espaços de tempo como passado - facticidade; presente - cuidado, preocupações; futuro - serpara-a-morte. O tempo é orientador para o indivíduo. Esse temporalizar ocorre em virtude do ser-aí (LOURENÇO, 2005).

Na perspectiva do cuidado, para Heidegger (1988, 1981), há duas maneiras de cuidar. Uma que é cuidar do outro pulando à sua frente, fazendo por ele, traduzido por este autor como inautêntico cuidar, e a outra maneira é estar junto dele, dando condições que o outro assuma seus próprios caminhos, através do apoio, da atenção do ensinamento e correção de comportamentos inadequados ou desfavoráveis à sua saúde e sendo, assim, autêntico com o outro.

Na visão heideggeriana, é o ser-com-o-outro, genuinamente, que pressupõe a capacidade de acolhimento. O cuidar é um fenômeno ontológico, porque nos leva a cuidar de nós mesmos ser-no-mundo que somos e dos outros enquanto ser-no-mundo-com-os-outros e, assim, construir uma relação de abertura com o outro.

O cuidar solícito, autêntico, desvela um ser-doente em sua temporalidade, visto como ser-aí presente e atuando no mundo a cada instante, e não apenas, como uma doença classificável em grupos de sintomas, o que possibilita abertura e (re)construção.

Essa maneira de cuidar consiste em antecipar-se à pessoa para favorecer que ela se perceba como indivíduo com possibilidade-para-ser. Isso ocorre à medida que o profissional 
consegue fazer o indivíduo voltar-se para si mesmo, de maneira originária, com o intuito que ele cuide de si mesmo, favorecendo a transparência e a liberdade desse ser humano (HEIDEGGER, 1981).

Portanto, essa maneira de cuidar assume uma atitude de solicitude, que pressupõe estar-junto-com-o-outro, proporcionando que assuma seus próprios caminhos, crescendo e encontrando-se consigo mesmo. Na perspectiva das agentes comunitárias, compreendendo isso, podem se reconhecer como seres em condições para ajudar, o que não raras vezes, significa estar-com-o-outro na sua dor, ouvindo-o e refletindo com ele suas escolhas e possibilidades sem, contudo, trazer respostas prontas e fechadas.

A origem (...) da determinação do homem como cuidado terá, portanto, um espaço não mais metafísico. Aliás, a introdução desta nova definição do homem não é proveniente de uma teoria sobre o homem. Ela nasce de uma descrição e de uma descrição fenomenológica, melhor ainda, de uma interpretação (...) (STEIN, 1988, p. 86).

É difícil perceber esse outro, como um ser que, mesmo apresentando aspecto sadio e perfeito, não consegue realizar os movimentos esperados para ele, pelos outros familiares, agentes de saúde e pela sociedade -, como andar, responsabilizar-se pela sua higiene, alimentação, organização espaço-temporal, o que repercute em todos a sua volta e, em especial, nos profissionais que os acompanham, deixando-os sem saber o que fazer ou como agir com esse indivíduo, que é percebido como ser em sofrimento, mas que, mesmo assim, não consegue ser compreendido e cuidado pelo outro.

Para Heidegger $(1988,1981)$, cuidar do outro exige uma atenção que ele denomina de solicitude orientada pela consideração e paciência. Consideração pelo sentir desse outro que, muitas vezes, expressa sentimentos que ele não compreende e, não raras vezes, o faz de maneira não adequada, causando mais sofrimento para si e para os outros, necessitando, então, que o at ajude-o a compreender esses sentimentos, suportar a angústia, a oscilação de humor e a frustração pelas recaídas, para assim conseguir ressignificar sua 
existência. Paciência para suportar com ele a sua dor, caminhando junto, não o deixando sozinho, mas também, não se antecipando a ele de maneira a fazer por ele.

Pensar o homem como cuidado é, considerá-lo em sua temporalidade, já que ela é constitutiva do cuidado, quando dimensiona o indivíduo como ser finitude que vive e é delimitado pela sua facticidade. Ao manifestar interesse em seguir o tratamento com o uso da medicação prescrita e de maneira correta, participação nos grupos terapêuticos e nos espaços lúdico-terapêuticos oferecidos pelos vários serviços disponíveis na cidade, o indivíduo portador-de-enfermidade-psíquica se lança à perspectiva de "reaver" o mundo, anteriormente, habitado por ele em que se encontrava livre de sofrimento, abrindo, assim, uma possibilidade de cura, explicitada na melhor qualidade de vida, na construção e realização de novos projetos, maior e melhor interação com o outro.

Estar-com-o-outro, percebendo-o como ser de desejos, direitos e deveres, nos coloca, muitas vezes, em confronto conosco mesmo, quando nos sentimos impossibilitados de ouvir e estabelecer contato com essa pessoa. $\mathrm{O}$ at relacionou-se com os colaboradores com uma atitude de solicitude libertadora, expressando amor desinteressado e, assim, libertando-o para si, portanto, o at buscou nesses atendimentos relacionar-se com eles de maneira a deixálos livre para ser e existir no mundo de modo próprio. 
7 - HORIZONTES DE COMPREENSÃO 
Pensar o indivíduo em sofrimento psíquico nos remete à dor, à angústia e ao sofrimento, próprios da condição humana de existir. Quando ele não é compreendido por outros seres humanos e pela equipe de saúde, ocorre um distanciamento entre quem sofre e o outro ser, seja familiar, seja pessoa da comunidade ou da equipe de saúde, ocasionando dor e exclusão. Na trajetória desta pesquisa, nossa proposta foi buscar compreender a percepção e os sentidos que o indivíduo em sofrimento psíquico, seu familiar e o agente comunitário que o atende têm do acompanhamento terapêutico ${ }^{32}$.

Durante o percurso do doutorado me deparei com uma gama de sofrimento tais como angústia e solidão (Ari, Daniela, Sandra, Edivânia, Vânia), dificuldades de relacionamento interpessoal com a mãe (Sandra, Elaine, Daniela), com o marido (Edivânia, Elaine) com os filhos (Elaine, Ari), com os irmãos (Vânia, Daniela), sentimento de impotência frente ao cotidiano (Ari, Daniela), resistência ao tratamento (Ari, Daniela, Vânia, Elaine), o que ocasionou, por motivos diversos, algum rompimento com a realidade como ocorrência momentânea ou não de adoecimento para essas pessoas.

Nesse sentido tive, como perspectiva, o atendimento do indivíduo portador de sofrimento psíquico, com intuito de ampliar seus movimentos e reconectá-lo ao seu cotidiano de maneira mais equilibrada, buscando, dessa forma, ajudá-lo a perceber sua dor, não a negando, mas sim, compreendendo-a e, assim, sentir-se mais livre e em condições para se reorganizar e viver de maneira mais autêntica.

Entretanto, tudo o que foi discutido até aqui não desvela para sempre a percepção e os sentidos do acompanhamento terapêutico, visto que a existência humana está envolta em uma organização social histórica e co-existencial que transcende e impulsiona o ser a um ir e vir ao fenômeno, favorecendo um aprofundamento sobre o mesmo.

\footnotetext{
${ }^{32}$ Esse capítulo o texto foi redigido em primeira pessoa por ser uma apreensão pessoal do trabalho da pesquisadora-doutoranda
} 
Nesse sentido, as compreensões apreendidas nesta investigação não permanecem desveladas para sempre de uma mesma maneira, pelo contrário, está em contínuo processo de mostrar-se já que a existência humana não é estática, mas se presentifica em um constante vir a ser favorecendo novos desvelamentos.

A análise das entrevistas ocorreu com o intuito primordial de compreender o fenômeno da atuação do acompanhamento terapêutico como instrumento terapêutico válido para o tratamento em Saúde Mental.

Pude apreender a dificuldade que os colaboradores tiveram de se relacionar com as pessoas ao seu redor, marido, mãe, irmãos, médicos, equipe de saúde e comunidade em geral. Essa dificuldade foi expressa de diversas maneiras como brigas (Elaine), desentendimentos (Ari), afastamento (Daniela), fuga de madrugada (Edivânia), expressando o isolamento que estavam vivenciando, a dificuldade de aceitar o sofrimento e a angústia como uma possibilidade existencial própria do ser humano.

Nos relatos dos familiares-colaboradores, evidenciou-se a dificuldade de verem o enfermo psíquico como uma pessoa que sofria, tinha limitações (Elaine, Vânia) ou estava momentaneamente adoecido (Ari). Apresentava capacidade reduzida de gerenciar sua vida, fazer escolhas assertivas e ponderadas (Daniela, Vânia, Edivânia), mas que podia exercer sua cidadania e sua liberdade de fazer escolhas (Sandra) e a liberdade de ir e vir. Tudo isso delimitou um distanciamento deles, ocasionando discussões, brigas, desentendimentos e exclusão.

As agentes comunitárias demonstraram a estranheza que a aproximação com o enfermo psíquico causa em algumas pessoas, denunciando as limitações que o Programa de Saúde da Família, ainda hoje, apresenta, seja pela não-existência de treinamento específico para atender essa população, seja pelo tempo que cada profissional de saúde precisa para aprender a olhar para o indivíduo, portador ou não de enfermidade mental, em suas 
potencialidades e não em suas deficiências e limitações e reconhecendo-se como profissionais que não apresentam competência técnica e, muitas vezes, sensibilidade para lidar com as dificuldades inerentes do trabalho com o indivíduo, portador de sofrimento mental.

Eu me propus, neste trabalho, pensar o acompanhamento terapêutico como alternativa de tratamento em saúde mental. Nesse sentido, foi possível compreender não somente a prática do Acompanhamento Terapêutico mas também o ser humano em sua estrutura fundamental como ser projeto em construção, ser-no-mundo, ser-com-o-outro, sercuidado. Essa terapêutica mostrou ser uma estratégia altamente eficaz como possibilidade de levar o indivíduo a viver de maneira mais autêntica e própria, assumindo a sua existência e dando sentidos mais plenos a suas vivências.

A ontologia heideggeriana desvelou a cotidianidade do existir do ser-enfermopsíquico, seus familiares e agentes comunitários. Na vivência desta pesquisa, tive a oportunidade de apreender os modos de ser-no-mundo desses colaboradores. Desvelando a dinâmica e vinculação do ser-enfermo-psíquico consigo mesmo e com o mundo, mostrando a singularidade dessa vivência.

Percebi que a sociedade cobra sempre do indivíduo adequação, adaptação, produção e, quando isso não acontece, ocorre exclusão, punição, cobranças. Atualmente, quando nossa sociedade torna-se mais complexa com exigências de especialização, perfeição e competência, percebo maior dificuldade do indivíduo que não apresenta altos níveis de realização pessoal para participar e contribuir com essa sociedade, adoecendo, ou não conseguindo participar de sua comunidade e, portanto, sendo excluído.

Os atendimentos em AT permitiram-me experienciar infinitas possibilidades de ampliar os movimentos dessas pessoas em seu cotidiano, favorecendo-lhes melhor qualidade de vida, expressa em maior participação na comunidade, adesão ao tratamento psiquiátrico, relacionamento interpessoal satisfatório com os familiares, com a comunidade e com o 
ambiente de trabalho, o que permitiu delinear o AT como terapêutica válida para o tratamento em saúde mental.

Trabalhar com Saúde Mental exige saber partilhar experiências e vivências, buscando transformar as posturas, já arraigadas, por novas idéias, comportamentos e vivências marcadas pelo afeto positivo de um outro olhar para o ser-em-sofrimento-psíquico. Um olhar que promova a construção de um saber e de uma prática que envolva ações e papéis flexíveis, dentro da equipe que cuida dessas pessoas.

Hoje em dia muito se tem falado em Saúde Mental, indivíduo portador de sofrimento psíquico, cuidado, inclusão dos familiares no tratamento, o que tem colaborado para uma mudança social importante em nossa sociedade, principalmente quando nos referimos à reabilitação psicossocial dessas pessoas.

Entretanto, ainda hoje, percebemos muita dificuldade em lidar com o enfermo psíquico, seja por não saber o que fazer, porque ele não apresenta rapidamente melhora significativa, por se tratar de uma pessoa com alguma dificuldade emocional que não tem nenhum quadro orgânico associado e demanda uma disponibilidade interna incomensurável por parte do cuidador e, ainda, porque nenhuma terapêutica é eficaz sempre com aquela pessoa e, portanto, ela precisa ser revista constantemente.

Muito há que ser feito. No PSF percebemos, ainda, uma atenção voltada para a execução de tarefas preestabelecidas com atenção na doença, em detrimento de um olhar para as relações e interações entre o indivíduo com sua família, com a comunidade onde reside e, também, com o serviço de saúde. Isso, sem contar com o despreparo dos profissionais para lidar com o indivíduo, contemplando-o em sua subjetividade.

Ressaltamos, também, que a prática em Saúde Mental no PSF exige quebrar os padrões arraigados que já estão prontos e são usados há anos, muitas vezes, sem reflexão e atualização. 
Ainda hoje, percebemos que o enfermo psíquico, mesmo quando tratado, está relegado a um lugar secundário na família. Sem ser percebido como um indivíduo em igualdades de condições de relacionamento com os outros, com suas potencialidades, habilidades e poder de contratualidade, o que favorece a reabilitação e maior inclusão social. Temos que ter em mente que nem sempre uma dificuldade constitui uma desabilidade.

É preciso, além da assistência humanizada, compreender o indivíduo como um ser em contínua interação com as pessoas ao seu redor e com a comunidade. Há que se favorecer/estimular que o ser humano exercite suas capacidades, ainda não exploradas, em face das limitações e dificuldades que apresenta. Nesse sentido, o at ajudou o indivíduo e sua família, já que olhou para esse indivíduo com dificuldades ou limitações de maneira cuidadosa. É como se estivesse com uma lente de aumento possibilitando um olhar que ampliou seus movimentos, o que permitiu um novo encontro entre ele e o outro - si mesmo, sua família, a comunidade e a equipe de saúde.

Propus com esta pesquisa levar uma terapêutica que favorecesse a ampliação das possibilidades do indivíduo enfermo mental se percebendo como ser de direitos e deveres provocando assim, ação e reflexão com intuito, principal, mas não o único, de buscar nos, serviços de saúde, nos grupos de apoio novas possibilidades para ser e agir no mundo. Nesse sentido, consegui sensibilizar a comunidade e profissionais que convivem com eles para essas novas perspectivas.

Nessa perspectiva este estudo possibilitou pensar o ser-enfermo-psíquico como um indivíduo cidadão e, como tal, uma pessoa que pode ser estimulada para maior participação na vida familiar e comunitária.

Porém, muita ainda há que ser realizado... 


\section{REFERÊNCIAS ${ }^{33}$}

${ }^{33}$ De acordo com: Associação Brasileira de Normas Técnicas. NBR 6023: informação e documentação: referências: elaboração. Rio de Janeiro, 2002. 
ABBAGNAMO, N. A. Fenomenologia. In: . História da filosofia. Lisboa: Editorial Presença, 1978. v. 14, p. 105-37.

ALMEIDA FILHO, N. For a general theory of health: preliminary anthropological and epistemological notes. Cadernos de Saúde Pública, v. 17, n. 4, p.753-70, 2001.

AMARANTE, P. A (clínica) e a Reforma Psiquiátrica. In: (Coord.) Archivos de saúde mental e atenção psicossocial. Rio de Janeiro: NAU Editora, 2003. p. 45-65.

Loucos pela vida - a trajetória da reforma psiquiátrica no Brasil. 2. ed. Rio de Janeiro: SDE/ENSP, 2000.

AYRES, J. R. C. M. Cuidado e reconstrução das práticas de saúde. Interface Comunicação, Saúde e Educação, v. 8, n. 14, p. 73-91, 2004.

BARRETO, K. D. Ética e técnica no acompanhamento terapêutico: andanças com Dom Quixote e Sancho Pancha. São Paulo: Unimarco, 1998.

BASAGLIA, F. A Instituição Negada. Rio de Janeiro: Grall, 1985.

BEAINI, T. C. A escuta do silêncio: um estudo sobre a linguagem do pensamento de Heidegger. São Paulo: Cortez: Autores Associados, 1981.

BELTRÃO, C. M. A formação do A.T. Séqüito. Belo Horizonte. 2002. Disponível em http://sequitoat.vilabol.uol.com.br/. Acesso em: 9 de out. 2002. 
BOTEGA, Neury José (Org). Serviços de Saúde Mental no Hospital Geral. Campinas: Papirus, 1995.

BRASIL. Ministério da Saúde. Programa Agentes Comunitários de Saúde - PACS. Brasília, 2000.

Ministério da Saúde. Secretaria de Assistência à Saúde. Saúde da Família: uma estratégia para a reorientação do modelo assistencial. 2. ed. Brasília: Coordenação de Saúde da Comunidade, 1998, 36 p.

Fundação Nacional da Saúde. Programa de Saúde da Família. Programa de Saúde da Família: saúde dentro de casa. Brasília, Ministério da Saúde, 1994.

BRÊDA, M. et al.Duas estratégias e desafios comuns: a reabilitação psicossocial e a saúde da família. Rev. Latino-Am. Enfermagem. Ribeirão Preto, v.13, n.3, maio/jun, 2005.

CABRAL, B. et al. Estação comunidade. In: LANCETTI, A. (Dir). Saúde e loucura: Saúde Mental e Saúde da Família. 2. ed. São Paulo: Hucitec, s/d. v. 7, 137-153 p.

CAIAFFA, R. de A. O acompanhante terapêutico e a rua: o social como constitutivo do acompanhamento. In: EQUIPE de acompanhantes Terapêuticos do Instituto A casa (org). A rua como espaço clínico. São Paulo: Escuta, 1991, p. 93-100.

CAMARGO, E. M. C. de. O acompanhante Terapêutico e a clínica. In: EQUIPE de acompanhantes Terapêuticos do Instituto A casa (org). A rua como espaço clínico. São Paulo: Escuta, 1991, p. 51-60.

CAMPOS, G. W. S. Reforma da reforma, repensando a saúde. São Paulo: Hucitec, 1992. 
CARVALHO, S. S. Acompanhamento terapêutico: que clínica é essa? São Paulo: Annablume, 2004.

CASTEL, R. A Ordem Psiquiátrica: a idade do ouro do alienismo. Rio de Janeiro: Graal, 1978.

CENAMO, A. C. V. et al. O setting e as funções no Acompanhamento Terapêutico. In: EQUIPE de acompanhantes Terapêuticos do Instituto A Casa (org). A rua como espaço clínico. São Paulo: Escuta, 1991, p. 107-207.

CHANAIDERMAN, M. Construindo possibilidades de clínicas multifacetadas: caleidoscópios cotidianos. In: PALOMBINI, A. de L. et al. Acompanhamento terapêutico na rede pública: a clínica em movimento. Porto Alegre: Editora UFRGS, 2004, p.13-6.

CORDEIRO, H. O PSF como estratégia de mudança do modelo assistencial do SUS. Cadernos Saúde da Família: Construindo um novo modelo. Ministério da Saúde, v. 1, jan/jun. 1996, p. 10-15.

COSTA, I. I. da. Da fala ao sofrimento psíquico grave: ensaios acerca da linguagem ordinária e a clínica familiar da esquizofrenia. Brasília: Izídio da Costa, 2003. 288 p.

COSTA-ROSA, A. O modo psicossocial: um paradigma das práticas substitutivas ao modo asilar. In: AMARANTE, P. Ensaios: subjetividade, saúde mental, sociedade. Rio de Janeiro: Fiocruz, 2000, p. 141-68.

CRITELLI, D. M. Analítica do sentido: Uma aproximação e interpretação do real de orientação fenomenológica. São Paulo: EDUC/Brasiliense, 1996. 142 p.

Educação e dominação cultural: tentativa de reflexão ontológica. 2. ed. São Paulo: Cortez/Autores Associados, 1981.

CRUZ, M. L. S. Realidades escondidas. In: LANCETTI, A. (Dir). Saúde e loucura: Saúde Mental e Saúde da Família. 2. ed. São Paulo: Hucitec, s/d. v. 7, p. 59-79. 
DARTIGUES, A. O que é fenomenologia? 9. ed. Rio de Janeiro: Livraria Eldorado, 2005.

DOMingueS, B. N. R. O Programa de Saúde da Família: como fazer? 2. ed. revista e atualizada. Campinas: Benito Narey Ramos Domingues, 1998. 238 p.

DUBOIS, C. Heidegger: introdução a uma leitura. Tradução Bernardo Barros Coelho de Oliveira. Rio de Janeiro: Jorge Zahar ed., 2004. 244 p.

ESPOSITO, V. H.C. Hermenêutica: estudo introdutório. Revista da Sociedade de Estudos e Pesquisa Qualitativos. São Paulo, v. 2, n. 2, p. 85-112, 1991.

FORGHIERI, Y. C. Psicologia fenomenológica: fundamentos, métodos e pesquisa. São Paulo: Pioneira, 1993.

FORTUNA, C. M. Cuidando de quem cuida: notas cartográficas de uma intervenção institucional na montagem de uma equipe de saúde como engenhoca-mutante para produção da vida. 2003, 236f.. Tese (Doutorado) - Escola de Enfermagem de Ribeirão Preto, Universidade de São Paulo, Ribeirão Preto, 2003.

FOUCAULT, M. Microfísica do poder. Rio de janeiro: Grall, 1979.

Doença mental e psicologia. Ed. Rio de Janeiro: Tempo Brasileiro, 1984. 
GILlES, T. R. Edmund Husserl. In: Gilles, T. R. História do Existencialismo e da Fenomenologia. São Paulo: EPU/EDUSP, 1975. v. 1, p. 129-85.

GOFFMAN, E. Manicômios, prisões e conventos. São Paulo: Perspectiva, 1974.

GUATARRI, F. As três ecologias. $4^{\text {a }}$ edição. Campinas: Papirus, 1993.

HALL, S. A identidade cultural na pós-modernidade. Trad. Tomaz Tadeu da Silva, Guaracira Lopes Louro. 10. ed. Rio de Janeiro: DP\&A, 2005.

HEIDEGGER, M. Ser e Tempo. Trad. Márcia de Sá Cavalcanti. 2. ed. Petrópolis: Vozes, $1988,2 \mathrm{v}$. 1981.

Todos nós... ninguém: um enfoque fenomenológico do social. São Paulo: Moraes,

HIRDES, A. Reabilitação psicossocial: dimensões teórico-práticas do processo. Erechim/RS: EdiFAPES, 2001, (série pensamento acadêmico; 10).

HYCNER, R. De pessoa a pessoa: psicoterapia dialógica. Tradução Elisa Plass Z. Gomes, Enila Chagas, Márcia Portella. São Paulo: Summus, 1995.

KAPLAN, Harold; SADOCK, Benjamin J. Tratado de psiquiatria. Tradução de Dayse Batista et al. 6.ed. Porto Alegre: Artes Médicas Sul, 1999. 2 v. 
LANCETTI, A. (Dir). Saúde e loucura: Saúde Mental e Saúde da Família. São Paulo: Hucitec, s/d a. v. 7.

LANCETTI, A Saúde mental nas entranhas da metrópole. In: LANCETTI, A. (Dir). Saúde e loucura: Saúde Mental e Saúde da Família. São Paulo: Hucitec, s/d b. v. 7, p. 11 - 52.

LEVCOVITZ, E.; GARRIDO, N. G. Saúde da Família: a procura de um modelo anunciado. Cadernos de Saúde da Família. Ano 1, n. 1, jan/jun, p. 3-8, 1996.

LIPOVETSKY, G. 1944. Tempos hipermodernos. Tradução Mário Vilela. São Paulo: Editora Barcarolla, 2004.

LOURENÇO, L.C. A. A angústia segundo Freud e Heidegger. 2005. 234 f. Tese (Doutorado) - Faculdade de Filosofia, Ciências e Letras de Ribeirão Preto, Universidade de São Paulo, Ribeirão Preto, 2005.

LUNARDELO, S. R. O trabalho do agente comunitário de saúde nos Núcleos de Saúde da Família em Ribeirão Preto. 2004. 156 f. Dissertação (Mestrado) - Escola de Enfermagem de Ribeirão Preto, Universidade de São Paulo, Ribeirão Preto, 2004.

MARQUES, M. R. M. Atelier bricoleur: intervenção no atendimento a psicóticos. In: EQUIPE de acompanhantes Terapêuticos do Instituto A casa (org). A rua como espaço clínico. São Paulo: Escuta, 1991, p. 101-7.

MARTINS, J.; BICUDO, V. M. A. A pesquisa qualitativa em psicologia: fundamentos e recursos básicos. 5. ed. São Paulo: Centauro, 2005. 
MAUER, S. K de, RESNIZKY, S. Acompanhantes terapêuticos e pacientes psicóticos: manual introdutório a uma estratégia clínica. Trad. Waldemar Paulo Rosa. Campinas: Papirus, 1987.

MENEZES, A. C. A percepção de pacientes psiquiátricos sobre suas famílias: um espelho de dois lados. 2001. 120 f. Tese (Doutorado) - Escola de Enfermagem de Ribeirão Preto, Universidade de São Paulo, Ribeirão Preto, 2001.

MICHELAZZO, J. C. Do um como princípio ao dois como unidade: Heidegger e a reconstrução ontológica do real. São Paulo: FAPESP: Annablume, 1999.

NITSCHKE, R. G. Mundo imaginal de ser família saudável: a descoberta dos laços de afeto como caminho numa viagem no quotidiano em tempos pós-modernos. Pelotas: Editora Universitária / UFPel: Florianópolis: UFSC, 1999.

Nascer em família: uma proposta de assistência de enfermagem para a interação familial saudável. 1991. 220 f. Dissertação (Mestrado em Enfermagem) - Centro de Ciências da Saúde, Universidade Federal de Santa Catarina, 1991.

OLIVEIRA, M. M. et al. A importância do Programa de Saúde da Família na reabilitação psicossocial. Resumo. In: Encontro de Pesquisadores em Saúde Mental, 8; Encontro de Especialistas em Enfermagem Psiquiátrica, 7. Ribeirão Preto: Maxicolor, 2004, p. 176.

OPAS/OMS. Reestruturación de la Atención Psiquiátrica em América Latina. Boletim Informativo, n. 4, 1994. 
OMS. Classificação Internacional de Doenças - CID-10. Trad. Centro colaborador da OMS para a Classificação das Doenças em Português. 7. ed. São Paulo: Editora da Universidade de São Paulo, 1999.

PALOMBINI, A. de L. et al. Acompanhamento terapêutico na rede pública: a clínica em movimento. Porto Alegre: Editora UFRGS, 2004.

PALOMBINI, A. de L. A clínica em movimento mais além das fronteiras institucionais. In: PALOMBINI, A. de L. et al. Acompanhamento terapêutico na rede pública: a clínica em movimento. Porto Alegre: Editora UFRGS, 2004. p. 23-6.

PALOMBINI, A. de L. Psicopatologia na vida cotidiana. In: PELliCCIOLI, E. et al. Cadernos de AT: uma clínica itinerante. Porto Alegre: Grupo de Acompanhamento Terapêutico Circulação, 1998, p. 45-51.

PASQUA, H. Introdução à leitura do Ser e Tempo de Martin Heidegger. Lisboa: Instituto Piaget, 1993.

PEREIRA, M. A. O. A reabilitação Psicossocial no atendimento em Saúde Mental: Estratégias em construção. 2003. 107 f. Tese (Livre-Docência) - Escola de Enfermagem de Ribeirão Preto, Universidade de São Paulo, Ribeirão Preto, 2003.

PITIA, A. C. Acompanhamento Terapêutico sob enfoque da psicoterapia corporal: uma clínica em construção. 2002. 119 f. Tese (Doutorado) - Escola de Enfermagem de Ribeirão Preto, Universidade de São Paulo, Ribeirão Preto, 2002.

PITTA, A. O que é reabilitação psicossocial no Brasil, hoje? In: PITTA, A. Reabilitação psicossocial no Brasil. 2. ed. São Paulo: Hucitec, 2001, p. 19-26. 
PONCIANO, E. L. T. O indivíduo e família na terapia de família. In: VENÂNCIO, A. L., Leal E. M.; Delgado, P. G. (org.). O campo da atenção psicossocial. Rio De Janeiro: Te Cora-Instituto Franco Basaglia; 1997. p. 47-51.

PORTO, M. SERENO, D. Sobre o acompanhamento terapêutico. In: EQUIPE de acompanhantes Terapêuticos do Instituto A casa (org). A rua como espaço clínico. São Paulo: Escuta, 1991, p. 23-31.

ROSA, W. A. G. A contribuição da saúde mental para o desenvolvimento do Programa de saúde da família. 2002. 129 f. Dissertação (Mestrado) - Escola de Enfermagem de Ribeirão Preto, Universidade de São Paulo, Ribeirão Preto, 2002.

ROTELLI, F. et al. Desinstitucionalização uma outra via - A reforma Italiana no contexto da Europa Ocidental e dos "Países Avançados". In: NICÁCIO, F. (org). Desinstitucionalização. 2. ed. São Paulo: Hucitec, 2001, p. 17-49.

SAMPAIO, J. J. C.; BARROSO, C. M. C. Centros de Atenção Psicossocial e equipes de Saúde da Família: diretrizes e experiências no Ceará. In: LANCETTI, A. (Dir). Saúde e loucura: Saúde Mental e Saúde da Família. São Paulo: Hucitec, s/d. v.7, p. 199-220.

SARACENO, B. Reabilitação psicossocial: uma prática à espera de teoria. In: PITTA, A. Reabilitação psicossocial no Brasil. 2. ed. São Paulo: Hucitec, 2001, p. 150-4.

Libertando identidades: da Reabilitação Psicossocial à Cidadania Possível.Rio de Janeiro: TeCorá, 1999. 
SCABELLO, E.H. Desvelando a dor amorosa da infidelidade conjugal: discursos de homens e mulheres. 2006. 327 f. Dissertação (Mestrado). Faculdade de Filosofia, Ciências e Letras de Ribeirão Preto, Universidade de São Paulo, Ribeirão Preto, 2006.

SCATENA, M. C. M. Saindo do Hospital Psiquiátrico: análise da inserção dos pacientes nos Lares Protegidos. 2000, 88 f.. Tese (Livre docência) - Escola de Enfermagem de Ribeirão Preto, Universidade de São Paulo, 2000.

SILVA, M. C. C. da. Acompanhamento terapêutico: do um ao outro, do porto ao mar. In: PALOMBINI, A. de L. et al. Acompanhamento terapêutico na rede pública: a clínica em movimento. Porto Alegre: Editora UFRGS, 2004, p.141-5.

SOARES, S. R. R. Centro de Atenção Psicossocial: como o usuário vivencia o cotidiano do serviço. 2005. 146 f.. Dissertação (Mestrado) - Escola de Enfermagem de Ribeirão Preto, Universidade de São Paulo, Ribeirão Preto, 2005.

SOUSA, M. F. A enfermagem reconstruindo sua prática: mais que uma conquista no PSF. Revista Brasileira de Enfermagem, Brasília, v. 53, no especial, p. 25-30, 2000.

SOUZA, R. C. de. Produção de sentidos por profissionais de saúde da família acerca do doente mental e dos cuidados a ele dirigidos. 2004. 192 p. Tese (Doutorado) - Escola de Enfermagem de Ribeirão Preto, Universidade de São Paulo, Ribeirão Preto, 2004.

SPANOUDIS, S. Apresentação. In: HEIDEGGER, M. Todos nós .... ninguém: um enfoque fenomenológico do social. São Paulo: Moraes, 1981, p. 9-22.

STEIN, E. Seis estudos sobre “Ser e tempo”. Petrópolis: Vozes, 1988. 
UNIVERSIDADE DE SÃO PAULO. Sistema integrado de bibliotecas. Centro de Computação de São Carlos. Diretrizes para apresentação de teses e dissertações à USP: documento eletrônico ou impresso. São Paulo: SIBI/USP, 2004.

VALLE, E. R. M. Cáncer infantil: comprender e agir. Campinas: Editorial Psy, 1997. 215 p.

VASCONCELOS, E. M. Reinvenção da Cidadania, Empowerment no Campo da Saúde Mental e Estratégia Política no Movimento de Usuários. In: Amarante P. Ensaios: subjetividade, saúde mental e sociedade. Rio de Janeiro: Fio Cruz, 2000, p. 169-93.

VIANA, A. L. D. \& DAL POZ, M. R. Reforma em saúde no Brasil: Programa de Saúde da Família; informe final. Estudos em saúde coletiva, Rio de Janeiro, n. 166, p. 3-35, 1998.

YALOM, I. D. O executor do amor: e outras estórias sobre psicoterapia. Tradução Maria Adriana V. Veronese. Porto Alegre: Artes Médicas, 1996.

YUNES, J. Apresentação. In: DOMINGUES, B. N. R. O Programa de Saúde da Família: como fazer? 2. ed. revista e atualizada. Campinas: Benito Narey Ramos Domingues, 1998. 
ANEXOS 


\section{ANEXO B}

TERMOS DE CONSENTIMENTO LIVRE ESCLARECIDO - clientes

Nome da Pesquisa:

“O Atendimento ao Indivíduo com Sofrimento Psíquico na Perspectiva de um Programa de Saúde da Família"

Pesquisadora Responsável: Marciana Gonçalves Farinha (doutoranda) e Maria Cecília Moraes Scatena (orientadora)

Meu nome é Marciana, sou psicóloga, CRP - 06 / 54.546 - 3, aluna de Doutorado da Escola de Enfermagem de Ribeirão Preto - USP, e estou realizando uma pesquisa com algumas pessoas que são atendidas no Centro de Saúde II do Centro de Saúde Escola da Faculdade de Medicina de Ribeirão Preto.

O objetivo desta pesquisa é buscar compreender a atuação do acompanhamento terapêutico a partir da percepção dos pacientes em sofrimento psíquico, seus familiares e os agentes comunitários que os atendem.

Os resultados desta pesquisa poderão ser usados por pessoas que trabalham com vocês, como agentes comunitários, enfermeiras, médicos, psicólogos e assistentes sociais e acompanhantes terapêuticos, para que possam oferecer um serviço de orientação e atendimento especializado.

Para tanto, gostaria de entrevistá-lo(a) a fim de colher informações para que eu possa alcançar este objetivo. Utilizarei uma pergunta norteadora: "Fale-me como você percebe a atuação do acompanhamento terapêutico no seu tratamento"?

Você terá liberdade de falar o tempo que quiser sobre essa experiência da maneira que achar melhor. Peço a permissão para gravar a entrevista, deixando claro que as suas informações serão utilizadas de modo que você não seja identificada.

$\mathrm{Eu}$,

RG

$\mathrm{n}^{\mathrm{o}}$ _ abaixo assinado, após tomar conhecimento das informações referentes às condições da pesquisa, e ciente dos meus direitos abaixo relacionados, concordo em participar, bem como afirmo que minha participação é totalmente espontânea e livre.

1. A garantia de receber a resposta a qualquer dúvida ou esclarecimento acerca dos procedimentos, riscos, benefícios e outros relacionados com a pesquisa;

2. A liberdade de o participante poder retirar seu consentimento após ter sido entrevistado. No caso de deixar de participar da pesquisa, o entrevistado não sofrerá nenhum tipo de ameaça ou prejuízo, sendo portanto este termo que foi assinado por ele, rasgado em sua presença.

3. Garantia de que o nome do (a) entrevistado (a) e o de outras pessoas citadas em seu depoimento não serão identificadas, já que seus nomes serão trocados por nomes fictícios, mantendo assim sigilo absoluto da entrevista;

4. Caso deseje informações atualizadas durante o estudo, o participante terá seu pedido prontamente atendido, ainda que estas informações possam influenciá-la na sua disponibilidade de participar da pesquisa.

Após o exposto acima, solicito que a entrevistada date e assine este termo o qual será assinado também por mim, ficando uma cópia com a entrevistada e a outra com a pesquisadora.

Ribeirão Preto, de de 200

Assinatura do participante

Responsável legal

Assinatura da pesquisadora 
ANEXO C

TERMOS DE CONSENTIMENTO LIVRE ESCLARECIDO - familiar

Nome da Pesquisa:

“O Atendimento ao Indivíduo com Sofrimento Psíquico na Perspectiva de um Programa de Saúde da Família"

Pesquisadora Responsável: Marciana Gonçalves Farinha (doutoranda) e Maria Cecília Moraes Scatena (orientadora)

Meu nome é Marciana, sou psicóloga, CRP - 06 / 54.546 - 3, aluna de Doutorado da Escola de Enfermagem de Ribeirão Preto - USP, e estou realizando uma pesquisa com algumas pessoas que são atendidas no Centro de Saúde II do Centro de Saúde Escola da Faculdade de Medicina de Ribeirão Preto.

O objetivo desta pesquisa é buscar compreender a atuação do acompanhamento terapêutico a partir da percepção dos pacientes em sofrimento psíquico, seus familiares e os agentes comunitários que os atendem.

Os resultados desta pesquisa poderão ser usados por pessoas que trabalham

com vocês, como agentes comunitários, enfermeiras, médicos, psicólogos e assistentes sociais e acompanhantes terapêuticos, para que possam oferecer um serviço de orientação e atendimento especializado.

Para tanto, gostaria de entrevistá-lo(a) a fim de colher informações para que eu possa alcançar este objetivo. Utilizarei uma pergunta norteadora: "Fale-me como você percebe a atuação do Acompanhamento Terapêutico no seu tratamento ?"

Você terá liberdade de falar o tempo que quiser sobre essa experiência da maneira que achar melhor. Peço a permissão para gravar a entrevista, deixando claro que as suas informações serão utilizadas de modo que você não seja identificada.

$\mathrm{Eu}$, $\mathrm{n}^{\mathrm{o}}$ , abaixo assinado, após tomar conhecimento das informações referentes às condições da pesquisa, e ciente dos meus direitos abaixo relacionados, concordo em participar, bem como afirmo que minha participação é totalmente espontânea e livre.

1. A garantia de receber a resposta a qualquer dúvida ou esclarecimento acerca dos procedimentos, riscos, benefícios e outros relacionados com a pesquisa;

2. A liberdade de o participante poder retirar seu consentimento após ter sido entrevistado. No caso de deixar de participar da pesquisa, o entrevistado não sofrerá nenhum tipo de ameaça ou prejuízo, sendo portanto este termo que foi assinado por ele, rasgado em sua presença.

3. Garantia de que o nome do (a) entrevistado (a) e o de outras pessoas citadas em seu depoimento não serão identificadas, já que seus nomes serão trocados por nomes fictícios, mantendo assim sigilo absoluto da entrevista;

4. Caso deseje informações atualizadas durante o estudo, o participante terá seu pedido prontamente atendido, ainda que estas informações possam influenciá-la na sua disponibilidade de participar da pesquisa.

Após o exposto acima, solicito que a entrevistada date e assine este termo o qual será assinado também por mim, ficando uma cópia com a entrevistada e a outra com a pesquisadora.

Ribeirão Preto, de de 200 
ANEXO D

TERMO DE CONSENTIMENTO LIVRE ESCLARECIDO - Agentes comunitárias

Nome da Pesquisa:

“O Atendimento ao Indivíduo com Sofrimento Psíquico na Perspectiva de um Programa

de Saúde da Família"

Pesquisadora Responsável: Marciana Gonçalves Farinha (doutoranda) e Maria Cecília Moraes Scatena (orientadora)

Meu nome é Marciana, sou psicóloga, CRP - 06 / 54.546 - 3, aluna de Doutorado da Escola de Enfermagem de Ribeirão Preto - USP, e estou realizando uma pesquisa com algumas pessoas que são atendidas no Centro de Saúde II do Centro de Saúde Escola da Faculdade de Medicina de Ribeirão Preto.

O objetivo desta pesquisa é buscar compreender a atuação do acompanhamento terapêutico a partir da percepção dos pacientes em sofrimento psíquico, seus familiares e os agentes comunitários que os atendem.

Os resultados desta pesquisa poderão ser usados por pessoas que trabalham com vocês, como agentes comunitários, enfermeiras, médicos, psicólogos e assistentes sociais e acompanhantes terapêuticos, para que possam oferecer um serviço de orientação e atendimento especializado.

Para tanto, gostaria de entrevistá-lo(a) a fim de colher informações para que eu possa alcançar este objetivo. Utilizarei uma pergunta norteadora: "Fale-me como você percebe a atuação do acompanhamento terapêutico no tratamento de pacientes com sofrimento psíquico"?

Você terá liberdade de falar o tempo que quiser sobre essa experiência da maneira que achar melhor. Peço a permissão para gravar a entrevista, deixando claro que as suas informações serão utilizadas de modo que você não seja identificada.

$\mathrm{Eu}$,

RG

$\mathrm{n}^{\mathrm{o}}$ _ abaixo assinado, após tomar conhecimento das informações referentes às condições da pesquisa, e ciente dos meus direitos abaixo relacionados, concordo em participar, bem como afirmo que minha participação é totalmente espontânea e livre.

1. A garantia de receber a resposta a qualquer dúvida ou esclarecimento acerca dos procedimentos, riscos, benefícios e outros relacionados com a pesquisa;

2. A liberdade de o participante poder retirar seu consentimento após ter sido entrevistado. No caso de deixar de participar da pesquisa, o entrevistado não sofrerá nenhum tipo de ameaça ou prejuízo, sendo portanto este termo que foi assinado por ele, rasgado em sua presença.

3. Garantia de que o nome do (a) entrevistado (a) e o de outras pessoas citadas em seu depoimento não serão identificadas, já que seus nomes serão trocados por nomes fictícios, mantendo assim sigilo absoluto da entrevista;

4. Caso deseje informações atualizadas durante o estudo, o participante terá seu pedido prontamente atendido, ainda que estas informações possam influenciá-la na sua disponibilidade de participar da pesquisa.

Após o exposto acima, solicito que a entrevistada date e assine este termo o qual será assinado também por mim, ficando uma cópia com a entrevistada e a outra com a pesquisadora.

Ribeirão Preto, de de 200 . 